NBER WORKING PAPER SERIES

\title{
ARE ELITE UNIVERSITIES LOSING THEIR COMPETITIVE EDGE?
}

\author{
E. Han Kim \\ Adair Morse \\ Luigi Zingales \\ Working Paper 12245 \\ http://www.nber.org/papers/w12245 \\ NATIONAL BUREAU OF ECONOMIC RESEARCH \\ 1050 Massachusetts Avenue \\ Cambridge, MA 02138 \\ May 2006
}

Email: ehkim@umich.edu; adairm@umich.edu; luigi.zingales@ chicagogsb.edu E. Han Kim acknowledges financial support from the Mitsui Life Financial Research Center at the University of Michigan; and Luigi Zingales, the Stigler Center at the University of Chicago. We have greatly benefited from the comments/suggestion of Marianne Bertrand and Caroline Hoxby and seminar participants at Duke, Harvard, MIT, the University of Chicago and the University of Michigan. We would like to thank Joyce Buchanan for editorial assistance and ESBCO Information Services and University Archives departments at Berkeley, Carnegie Mellon, Chicago, Columbia, Cornell, Duke, Harvard Indiana, Michigan, MIT, Northwestern, NYU, OSU, Penn, Princeton, Purdue, Rochester, Stanford, Texas, Washington, UCLA, USC, Wisconsin, and Yale for faculty rosters. The views expressed herein are those of the author(s) and do not necessarily reflect the views of the National Bureau of Economic Research.

(C2006 by E. Han Kim, Adair Morse and Luigi Zingales. All rights reserved. Short sections of text, not to exceed two paragraphs, may be quoted without explicit permission provided that full credit, including (C) notice, is given to the source. 
Are Elite Universities Losing Their Competitive Edge?

E. Han Kim, Adair Morse and Luigi Zingales

NBER Working Paper No. 12245

May 2006

JEL No. D85, I23, J24, J31, J62, L23, L31, O33

\begin{abstract}
We study the location-specific component in research productivity of economics and finance faculty who have ever been affiliated with the top 25 universities in the last three decades. We find that there was a positive effect of being affiliated with an elite university in the 1970s; this effect weakened in the 1980s and disappeared in the 1990s. We decompose this university fixed effect and find that its decline is due to the reduced importance of physical access to productive research colleagues. We also find that salaries increased the most where the estimated externality dropped the most, consistent with the hypothesis that the de-localization of this externality makes it more difficult for universities to appropriate any rent. Our results shed some light on the potential effects of the internet revolution on knowledge-based industries.

E. Han Kim

University of Michigan

Business School

Ann Arbor, Michigan 48109-1234

ehkim@umich.edu

Adair Morse

701 Tappan Street

Ann Arbor, MI 48109-1234

adairm@umich.edu

Luigi Zingales

Harvard University

Littauer Center

Cambridge, MA 02138

and NBER

luigi.zingales@chicagogsb.edu
\end{abstract}


During the internet boom in the 1990s the possibility that traditional teaching would be replaced with Web-based classrooms was considered a sufficiently serious threat that most major universities devised an "internet strategy". Ten years later, much of this debate has subsided and traditional classroom teaching is expected to continue its dominance in the foreseeable future.

Surprisingly, a similar debate has not taken place about how the internet could modify the other production process taking place in universities: namely, research. A compelling case can be made that the internet and the concomitant decline in communication costs have changed the localized nature of research interaction. While collaboration across universities was common before the advent of the internet, local interaction was very important. Communication at a distance was costly, both from a monetary and a technical point of view. Large datasets, for instance, were hard to move from computer to computer, and it was extremely tedious to share regression results at a distance. All this, of course, has changed. How did these changes modify the nature of the production of academic research? Did local interaction become less important? If so, how does this decline affect the value added of elite universities and hence their competitive edge? These questions are important not only for academia but also for all knowledge-based production. How has the internet, for instance, modified the competitive advantage of Silicon Valley in the software industry?

This paper attempts to answer these questions by examining research productivity in top economics and finance departments over the last three decades. Using the academic setting has several advantages. Individual output is measurable (number of pages published in academic journals), and it is possible, while labor intensive, to trace who is where over a long period. These conditions allow us to determine whether location plays a role in individual productivity in a knowledge-based industry. We do so by tracing people's moves across universities.

We find that in the 1970s, residence in an elite university had a sizeable impact on individual productivity. During that time, a random economic faculty member moving from a non-top 25 university to Harvard would see her productivity increase by 2.1 American Economic Review (AER) impact-equivalent pages per year, which is tantamount to almost doubling her research productivity. In the 1990s this effect all but 
disappeared. And the disappearance is not just a Harvard phenomenon. Of the top 25 economics departments studied, 17 (5) had a significantly positive (negative) impact on productivity in the 1970s. By the 1990s only 2 (9) had a significantly positive (negative) effect. The corresponding numbers for finance are 16 (3) and 4 (7).

These results do not seem to stem from endogenous selection inherent in location decisions. We carefully consider four selection stories -- quasi-retirement, nonpromotion, complementarities, and tournaments. The patterns of post-move changes in productivity do not support any of these selection stories. Nevertheless, we formally address possible selection bias in faculty moves by estimating a two-stage selection model. We use a logit model to estimate the probability of moving as a function of age, and a conditional logit model to estimate the probability of being at each location (given a move) as a function of the desirability of each location for individual faculty. The desirability is captured by the distance to the individual's origin (defined as the location of the alma mater undergraduate university), and the relative productivity difference to incumbent faculty. Using the predicted unconditional probability of being at a location as an instrument for the university indicators, the results remain materially the same.

The declining university effects on productivity over the last three decades may not be necessarily due to advances in information technology. A simpler explanation is that other universities are catching up, in terms of quality of the faculty, to the top academic universities. Our data tell a different story; the difference in average individual faculty productivity between the top 25 universities and the rest has increased (not decreased) in the last three decades.

Another possible explanation is that a sudden shift in the production frontier created a first mover advantage in the 1970s, which slowly eroded in the subsequent two decades. While this explanation is plausible for finance, which really took off as a separate field in the 1960s, this cannot be true for economics because it was a wellestablished discipline four decades ago.

Rejecting these alternatives, we test some implications of the internet-based explanation. The most direct implication is that the externality of having better research colleagues declined over the sample period. Indeed, this is what we find. We measure colleagues' quality with their average past productivity. In the 1970s, faculty who work 
with better colleagues are more productive, consistent with Laband and Tollison (2000). This effect diminishes in the 1980s and vanishes in the 1990s. In contrast, the role of cultural norms in a department, as measured by the percentage of non-productive colleagues in a department, retains a persistent negative effect on the university's impact on individual productivity.

We find that during the same period co-authorship at a distance rises steadily perhaps due to the reduced importance of physical proximity. Among all articles published in the top 41 journals written by scholars residing at a top 25 school, the percentage of co-authored papers with colleagues in a non-elite school has nearly doubled, from about $32 \%$ in the beginning of the 1970 s to $61 \%$ by 2004 , suggesting that it has become much easier for authors at non-elite universities to access scholars at elite universities.

The de-localization of the externality produced by more productive researchers has important implications in academia. First, it makes the position of leading universities less stable. While in the 1970s it was difficult for less prestigious universities to compete on an equal footing with top institutions, which were able to offer to new recruits the positive externality associated with productive colleagues, this is not true anymore. Delocalization of production externalities renders faculty more mobile, making it easier for a new place to attract away the most talented researchers with higher salary. And this is the second important effect. When this externality was localized, universities could more easily appropriate the rents. Today, with the universal access to knowledge, faculty should be able to capture more of the benefits from the externalities. We find evidence consistent with this prediction in the average salaries at different institutions: Between the 1970s and the 1990s, faculty salaries have increased the most at universities where the estimated externality drops the most.

These results have important implications outside of academia as well. Traditionally, physical access to the firm was important for knowledge-based production. If - as the faculty productivity data seem to show - improvements in communication technology have made low-cost access at a distance possible for production purposes, then firms have lost a powerful instrument to regulate and control the accumulation and utilization of knowledge. Appropriating the return to investment in research and 
development will become more difficult and firms' boundaries will become fuzzier. The implications extend far beyond what we document here. A firm's inability to contain externalities inside the firm may shift the foci of migration to a more dispersed paradigm and may extend the role of outsourcing well beyond what we experience today. Governments may be compelled to react to the changing meaning of proximity and of firm boundaries through regulatory changes on matters concerning labor, competition, and industry.

Our work is most closely related to Laband and Tollison (2000), Rosenblat and Mobius (2004) and Goyal, Van Der Leij, and Moraga (2006), who study the role of collaboration, communication, and networks among faculty in research production. Rosenblat and Mobius (2004) offer a theoretical framework in which low communication costs not only make it easier for people to work together at a distance but also cause splintering into work groups aligned along social lines. Along a similar line, Goyal et al. (2006) find that as decreased communication costs facilitate distant working relationships, the entire network of economists has become more interconnected. Laband and Tollison (2000) also find that co-authorship in economics is growing rapidly, but the formal collaboration (co-authoring) is not replacing the growing role of informal intellectual feedback on article preparation. In part, Laband and Tollison's result may reflect the need and opportunity for feedback due to the slowdown in the publication process documented by Ellison (2002). The notion that decreasing communication costs have opened vaster research networks is consistent with our findings of declining university fixed effects and increasing co-authorship between faculty at elite and nonelite universities.

The rest of this paper proceeds as follows. Section I presents the data. Section II reports estimation of the university fixed effects, followed by an examination of potential selection biases influencing the results in Section III. Section IV decomposes university fixed effects onto institution-wide characteristics and relates the changes in university fixed effects to faculty compensation, and Section V concludes. 


\section{Data}

To study the effect of location on research productivity, we collect data on individual research productivity for a large panel of faculty. Special care is exercised to ensure that we identify the location of faculty during the production of articles, not at the publication date. Additionally, we cautiously choose measures of productivity that are comparable over three decades.

\section{A. Faculty sample selection}

Because it is difficult to collect career information for all academic fields, we restrict our attention to years 1970-2001 and to the fields of economics and finance, which, not coincidently, are the areas of the authors' expertise. Since location-specific effects are likely to be strongest among top universities, our analysis is focused on top research institutions. We collect data on research productivity for all individuals who have ever been affiliated (tenure track or visiting) with top 25 universities.

To choose the top 25 universities, we average university research rankings provided by eleven previous studies. These studies employ a broad range of methodologies and journals to rank departments over 1970-2001 sub-periods. Relying on these studies alleviates some of the subjectivity inherent in using a single ranking methodology. Table 1, panel A lists the sub-periods covered and the methodologies used by the eleven studies.

Using the Borda Count (de Borda, 1781) method to average the rankings from the eleven studies, a university that is ranked first in a study is given 20 points; the second ranked university is allocated 19 points, and so on. We then average the rankings, individually for finance and economics, weighting each study's allocated points by the number of years covered by the study. The scores for finance and economics are averaged (with equal weighting) for each university. The average reported in Table 1, panel B, shows a natural break point in score magnitude at the twenty-fifth university. ${ }^{1}$

\footnotetext{
${ }^{1}$ The average of finance and economics rankings may result in the inclusion of schools which would not be ranked highly in one of the two departments. For example, Princeton has no finance department but still made the top 25 because of their high ranking in economics. In the case of UBC, the ranking is largely driven by the high ranking scores of its finance department.
} 
One might argue that classification of 25 universities as being elite may be too broad. As a robustness check, we run all of our estimations based on classifying only top ten schools as being elite. The conclusions do not change.

Faculty affiliation is based on where individuals self-report their location each year, not the affiliation reported in published articles. Identifying the physical location of individuals during the production process is crucial to estimate a university effect on productivity. Thus we undertake a painstaking three-step procedure to manually compile the appropriate faculty affiliation.

First, we extract curriculum vitaes (cv's) from websites for finance and economics faculty currently employed by the top 25 universities. ${ }^{2}$ Second, we look at every individual's cv for every economics and finance faculty for all universities included in Business Week's top 100 business schools and the National Research Council's top 100 economics programs for 2002 (a total of 138 additional universities). If an individual in the additional universities ever held a position in any of our top 25 universities, that person is included in the dataset. Third, we capture faculty who moved to other professions, retired, or passed away during our sample period by contacting the archives of each of our 25 universities to request a faculty roster for the economics and finance departments over 5-year intervals starting in 1973; namely, 1973, 1978, 1983, and 1988. ${ }^{3}$ These archives and obituary records, supplemented with the Hasselback-Prentice Hall Guide to the Finance Faculty for 1993, provide the majority of the missing names for the earlier periods.

From faculty cv's, we extract individuals' university affiliations and position ranks over time, as well as doctoral and undergraduate degree institutions and graduation years. When the websites publish only biographical sketches that do not contain the full historical detail, we fill in unavailable data following a series of procedures. We email a subset of individuals to request their full vitae. We also use relevant statistics derived from the set of full cv's of other faculty members to fill in estimates of the missing

\footnotetext{
${ }^{2}$ This work was conducted during the period May, 2003 to March, 2004.

${ }^{3}$ A few universities were unable to supply us with the archive reports. For these schools, we searched the university websites for records of department retirements and obituaries from the 1970s and 1980s.
} 
variables. ${ }^{4}$ The result of our efforts is a dataset of 3,262 faculty members whose careers touch over 800 universities.

\section{B. Publication sample selection}

Measuring research productivity requires selecting a reasonable number of economics and finance journals. To avoid making choices based on our priors, we use all of the 36 economics journals and the top five of the finance journals used by the ranking studies summarized in Table $1 .^{5}$ We exclude all but the top five finance journals in an effort to equalize the minimum quality standard across finance and other economic subfields. This is important because the calculations of productivity are pooled across all economics subfields, including finance. With these five finance journals, our data show that the average (impact-weighted) productivity of finance faculty is roughly equivalent to that of economics faculty.

We obtain article information for the period 1970-2004 from two sources. Our primary source of data is EBSCO Information Services, a publication data vendor. The EBSCO download consists of 73,039 articles, representing 48,917 author names and 111,150 unique article-author observations. ${ }^{6}$ We hand match the EBSCO author names to our list of 3,262 faculty to capture inconsistencies in naming conventions. Of the 111,150 article-author observations, 25,010 of them correspond to our list of faculty ever

\footnotetext{
${ }^{4}$ Missing Ph.D. years are replaced with the first year that the person appears as an assistant professor in our database. If the first assistant professor year is 1970, which is the start date for our database, or if the person is never an assistant professor in our database, the Ph.D. year is replaced with the undergraduate graduation year plus 6 years, the median time between degrees in our sample of full cv's. Likewise, missing undergraduate graduation years are inferred from the Ph.D. year. If we are unsure of promotion years, we infer promotion dates using the university department's decade average time spent in each promotion rank, which is again computed from our sample of full cv's for that university. Finally, if the individual retired, passed away, or otherwise disappeared such that we are unable to locate a website or a $\mathrm{cv}$ at all (less than $10 \%$ of the cases), we infer institutional attachment via affiliations cited on journal articles.

${ }^{5}$ The list of 36 economics journals comes from the union of all journals covered by the four studies shown in Table 1 which do not use the universe of journals in the Social Science Citation Index or EconLit. The top 5 finance journals according to Arnold, Butler, Crack, and Altintig (2003) are Journal of Finance, Journal of Financial Economics, Review of Financial Studies, Journal of Business, and Journal of Financial and Quantitative Analysis. Econometrica is also included in Arnold et al.'s list and is already included in the economics list.

${ }^{6}$ EBSCO's classification scheme allows us to discard comments, notes, book reviews, and other non-article publications. We discard articles with less than three pages and verify the page count and content for articles with three-four pages or page counts greater than 69 .
} 
affiliated with the top 25 universities. We also collect citation counts for each article by downloading them from the ISI Web of Science / Social Science Citation Index (SSCI). ${ }^{7}$

To approximate the timing when the actual work was performed, we lag the publication date of articles to account for time spent in research and write-up, the peer review process, and journal publication backlog. The lag adjustment is complicated by the variance of lags in review and in publication across journals. Fortunately, Ellison (2002) calculates the decade average submission-to-acceptance time in months for 20 journals included in our sample. For the other journals, we use the average lag time of the economics or finance journals included in Ellison. ${ }^{8}$ Ellison's lag, however, does not include the lag from acceptance to publication and from work to submission.

The lag between acceptance and publication varies depending on the journal backlog. To estimate this lag, we look at two journals (the Review of Economic Studies (RES) and the Journal of Financial Economics (JFE)) that report the acceptance date of each paper. For each year in 1970-2002, we randomly 15 articles from the RES and JFE and calculate the mean lag time from submission to publication. Figure 1, Panels A and B, present plots of these sampled lag times, depicted as the solid line. Ellison's lag times (the dashed line) are smaller because the sampled lag time includes Ellison's submissionto-acceptance estimate plus the publication backlog time. To account for the time spent between acceptance and publication (seven months on average) and the time between the middle-of-writing and submission, we add one year to Ellison's lag. Our final lagging time is represented by the upper grey dashed line.

\section{Productivity measures}

After mapping publications to the year and place of production, we aggregate pages from different journals into a yearly measure of individual productivity. Because

\footnotetext{
${ }^{7}$ The Web of Science data have several limitations. Often all but the first author are excluded from the author lists when the number of coauthors is greater than two (Alexander and Mabry, 1994), and the author first names are abbreviated. Although matching the abbreviated names to publications with precision is difficult, we circumvent the problem by mapping the journal issue and page range to the EBSCO data. ${ }^{8}$ More precisely, for finance journals not included in Ellison, we use the average of the Journal of Finance and the Journal of Financial Economics, the two finance journals covered by Ellison, for the 1980s and 1990. For the 1970s we only use the Journal of Finance lag because the JFE started in the mid-1970s and had unrepresentatively short publication process time during the 1970s.
} 
typesetting, page length conventions and quality differ across journals, we follow the standard approach of converting measures of productivity into $A E R$ equivalents.

The four most commonly used measures of academic productivity are counts of articles written, ${ }^{9}$ raw counts of publication pages, ${ }^{10}$ citations to published articles, ${ }^{11}$ and impact-weighted counts of pages where impact is gauged by the citations to the journal in which the publication occurs. ${ }^{12}$ Each measure has strengths and weaknesses, which we discuss briefly as we describe their calculation. ${ }^{13}$

The count of articles published is the simplest productivity measure and is calculated by summing the number of articles each individual publishes in the 41 journals each year. The shortcoming of this measure is its inability to distinguish between main articles and shorter articles: all of them count the same. The second, easier to address, problem is that it is a very discrete measure. In spite of these shortcomings, we include article count in our selection of measures to alleviate concerns of article length inflation over time, which we shall discuss momentarily.

The second measure of productivity, raw productivity, is calculated by summing pages published, adjusted to $A E R$ equivalents and divided by the number of coauthors in each article, for individual $i$ in year $t$ across all journals $j$.

$$
\text { Raw }_{i t}=\sum_{\text {articles }_{i t}}\left[\frac{\text { pages }_{i j t}}{\text { coauthors }_{i j t}} \cdot(\text { AER equivalent adjustment })_{j t}\right]
$$

The number of pages and coauthors for each article are from the EBSCO dataset. ${ }^{14}$ The $A E R$ equivalent adjustment normalizes each journal to the length of the $A E R$ to account for different typesetting and conventions in article lengths. We follow Graves, Marchand, and Thompson (1982) in normalizing both the average number of pages per article and

\footnotetext{
${ }^{9}$ Heck, Cooley, and Hubbard (1986)

${ }^{10}$ Klemkosky and Tuttle (1977); Graves, Marchand, and Thompson (1982); Niemi, (1987); Scott and Mitias (1996)

${ }^{11}$ Davis and Papanek (1984); Blair, Cottle, and Wallace (1986)

${ }^{12}$ Liebowitz and Palmer (1984); Alexander and Mabry (1994); Laband and Piette (1994); Borokhovich , Bricker, Brunarski, and Simkins (1995); Conroy and Dusansky (1995)

${ }^{13}$ Other measures of individual productivity in economics and finance research include representation on editorial boards (Kaufman, 1984) and references in graduate-level texts (Liner, 2002).

${ }^{14}$ Page counts were missing in 3\% of the article-author observations. We use the average pages for the appropriate journal and year for these observations. Normalizing by the number of coauthors is consistent with the findings of Sauer (1988) that the salary return to papers coauthored by $\mathrm{n}$ authors is approximately $1 / \mathrm{n}$ the return of a solo authored paper.
} 
words per page to the $A E R{ }^{15}$ The normalization of raw to the $A E R$ equivalent allows productivity assigned to an individual to be interpreted as the number of $A E R$ pages produced in a given year.

Raw page counts are simple to use and easy to understand, but they do not assess the quality of articles. One way to assess the quality of articles is to use the citation method, which weights every article by its number of citations as recorded in the Social Science Citation Index (SSCI). Citations are perhaps the most direct measure of an article's influence. This method, however, has four potential flaws, some of which are particularly severe for our purposes.

First, SSCI counts citations from thousands of journals, not just from journals at the forefront of the research in the field. Second, citations create a bias in terms of fields or type of articles. For example, survey articles tend to be heavily cited, and 9 of the 20 most-cited articles in economics are econometric foundation papers (e.g., White (1980)).

Third, citations are highly skewed, magnifying possible misidentification of faculty's affiliation at a particular point in time. If the time lag applied from publication to writing is incorrect for a ground-breaking article, a huge number of citations belonging to one institution would be inappropriately credited to the wrong institution.

Groundbreaking articles are more susceptible to misidentification because they are more likely to face longer than average delays in the publication process. Given the disproportionate weights that these articles carry in terms of citations, a mistake would have an enormous impact on the estimates. Even without a mistake, the influence factors of high-citation observations would imply that a few observations completely determine the OLS estimates.

The final and, perhaps, most immediate obstacle to the use of citations as a measure of productivity is that they have a lifetime of their own. Citations-per-year tend be low initially, peak after roughly thirteen years, and then decline slowly. Hence, to measure the impact of recent papers we would have to predict future citation on the basis of early ones, making it difficult to compare productivity in the 1970s with productivity in the 1990s.

\footnotetext{
${ }^{15}$ In making the page count adjustment, we exclude the AER Proceedings issue. To obtain the word-perpage adjustment, we count the number of words for a standard, non-equation page for each of the 41 journals for three decade observations: 1975, 1985, and 1995.
} 
The impact-weighted count of pages, impact productivity, is a compromise between raw productivity and citation counts, incorporating key features of each. We follow the non-iterated method of Liebowitz and Palmer (1984) and Laband and Piette (1994), in which publication pages are credited to the individual faculty as in the raw productivity calculation, and the credit is weighted by number of citations to the journal in which the publication appears. The impact productivity is defined as:

$$
\text { Impact }_{i t}=\sum_{\text {articles }_{i t}}\left[\frac{\text { pages }_{i j t}}{\text { coauthors }_{i j t}} \cdot\left({\text { AER equivalent adjustment })_{j t}} * \text { ImpactFactor }_{j d}\right]\right.
$$

The impact factor for journal $j$ in decade $d$ is simply the number of citations to journal $j$ appearing in the references of all articles in the source journals $s: s \in\{1, \ldots, 41\}$, defined according to the formula:

$$
\text { ImpactFactor }_{j d}=\frac{\sum_{\text {articles }_{\text {in }} \in \text { cites }_{\text {sjd }} ., 41} \cdot(\text { AER equivalent adjustment })_{s d}}{\text { ImpactFactor }_{A E R, d}},
$$

We make the same $A E R$ equivalent adjustment in both the number of articles and the words per article and normalize each impact factor to that of the $A E R$.

Calculating impact factors based on the SSCI would be subject to the same criticism as using citations; namely, they draw from the universe of all journals, and not journals at the forefront of research. Thus, we create impact factors custom-made to our need. We manually count citations of each of the 41 journals by reviewing the reference lists of every article in the 41 journals for three base decade years, 1975, 1985, and 1995. If one of the authors writing the article is self-cited, the citation is excluded. This method allows for variation in journal impact over decade. In total, we collect reference counts for over 6,000 articles. The adjustments and normalizations allow us to interpret impact productivity, Impact $_{i}$, as the number of $A E R$ impact equivalent pages.

Table 2 shows impact factors and the decade rank of the impact factors for 36 economics journals and 5 finance journals (with the Journal of Business classified as a finance journal) for the 3 decades. Although the rankings of journals is generally persistent (with a Kendall's tau-b rank correlation of approximately 0.70 across decades), the table reveals some noteworthy changes. The Journal of Finance jumped from the 
eighth position in the 1970 s and 1980 s to the second position in the 1990 s. ${ }^{16}$ In the meantime the Journal of Economic Theory (JET) declined from the thirteen position in the 1970 s, to fifteenth in the 1980 s and twenty-ninth in the 1990s. The JET trend is characteristic of economic journals, many of which have dropped in impact rankings over time.

Laband and Piette (1994) report impact factors using the larger set of SSCI journals, which give more weight to lower-tier journals, for roughly the same time periods as our 1970s and 1980s calculations. They also adjust for article counts that include comments and note. In spite of these differences, the correlation between our impact factor and theirs is 0.88 in the $1970 \mathrm{~s}$ and 0.83 in the $1980 \mathrm{~s}$.

\section{Summary statistics}

Table 3 reports the summary statistics and correlations of the four canonical measures of individual productivity. The mean raw productivity per faculty (6.3) is approximately double that of impact (3.1) over the entire period. The average number of articles is 0.62 per year. Both raw and impact measures increase from the 1970 s to the 1980s, with a slight reversion in the 1990s. In contrast, article counts have steadily declined from 0.75 in the 1970 s to 0.53 in the 1990 s. The medians are zero for all three measures over all three decades.

The statistics concerning citations illustrate our reservation to use it as a productivity measure. We download citations (through 2005) for each article published during the three decade periods. The mean citation counts for the articles published in the $1990 \mathrm{~s}(7.8)$ is less than one-third of those of the two previous decades $(27.5,25.7)$,

\footnotetext{
${ }^{16}$ Liebowitz and Palmer (1984) also develop an iterated impact factor method, which weights the citations to each journal according to the impact factor of the source journal citing the reference. Calculation of the iterated impact factor results in large impact factors for finance journals vis-à-vis general economics or, in particular, other economics subfields. Specifically, the Journal of Finance and the Journal of Financial Economics rank first and second in the 1990s under this method. Although this is interesting and warrants further study to examine the causes, the large finance impact factor makes it difficult to compare research productivity across economic subfields. If we were to use the iterated impact factors, an economics faculty publishing in a finance journal would be given more weight relative to her colleagues publishing in other subfields, making the comparison somewhat inequitable. The large finance impact factor is also partially due to insular citing within the finance field because, unlike other economics subfields, finance is a separate department. Finally, all the authors of this paper are from finance departments; thus, we would rather take the risk of underestimating the impact of finance rather than the risk of getting caught in a controversy over the relative impact of economics versus finance.
} 
demonstrating the timing problem of using citations. Statistical problems also appear in the standard deviations and skewness. For the 1970s, for example, standard deviation for citations is 4.4 times as large as the mean, whereas none of the standard deviations for raw, impact, and article counts exceeds two times the magnitude of the mean. The skewness for citations is approximately 14; for the other measures, the skew ranges between 2 and 3.

Table 3, Panels B and C, present the correlations among the four productivity measures. The rank correlations are high for all combinations of measures. However, the Pearson correlations for citations with any of the other measures lose half of their magnitude, although they remain positively significant and strong. The lower linear correlations are due to the huge skewness in citations counts, validating our decision to omit citations as a measure of productivity.

\section{E. Productivity Comparability over Decades}

Because we are interested in productivity over time, it is important that we are able to compare a unit of productivity output across decades. To check the comparability over time, first consider the shifts in supply of and demand for manuscripts submitted for publication during the three decades. The ratio of supply (the number of manuscripts submitted) over demand (the number of articles published) in $A E R$ was 7.2 in the first five years of the 1970s, which almost doubled to 12.7 in the last five years leading to 2002. ${ }^{17}$ This suggests that a simple AER article count measure would undervalue productivity in 2000 relative to the 1970s. Consistent with this conjecture, Panel A in Table 3 shows a steady decline in the average article counts over the three decades.

\footnotetext{
${ }^{17}$ These data are from the Reports of the Editor published each year. The increase in manuscripts submissions may be attributed to three possible sources - more time per faculty for preparing manuscripts, more faculty per university, and more universities participating in the publication market. Although difficult to quantify precisely, teaching loads have been reduced substantially over the three decades, allowing more time for research production. The growth in faculty per university can be estimated using the archive reports of faculty rosters. We find that the growth in the size of economics (finance) faculty for the top 25 schools is cumulatively $26 \%$ (69\%) from 1973 to 2001 . These figures capture only the intensive margin, ignoring the growth in the number of institutions with faculty submitting to top journals. Heck, Cooley, and Hubbard (1996) find that whereas 201 institutions are represented in the $J F$ during 1966-1975, 270 institutions are represented in the 1975-1985 JF publications, corresponding to a $34 \%$ growth in the extensive margin for finance. Goyal et al. (2006) document that the number of authors publishing (not trying to publish) in existing EconLit journals rose from 22,960 in the 1970s to 32,773 in the 1990s, a 43\% increase.
} 
However, Ellison (2002) finds that a 2000 article is twice as long as a 1970 article. ${ }^{18}$ Indeed the number of pages per article has doubled for the $A E R$ over the same period, making the ratio of pages submitted to pages published roughly constant over time. Although this might suggest the use of raw productivity as the time-comparable measure, this calculation does not factor in the increase in the number of journals. Of the 41 journals in our sample, only 24 existed in 1970. With the additional pages from new journals, raw productivity will over-estimate productivity in later years.

A compromise measure is found in impact productivity, which removes the effect of the increase in number of journals. When a new journal arrives, it competes with existing journals for citations, often diminishing the impact factor of other second-tier journals. The impact productivity measure also diminishes the article inflation because most article inflation occurs in second-tier journals, which are given lower impact weights. Consistent with this intuition, Table 3 shows that individual average impact productivity has remained fairly constant over three decades. Thus we focus on impact productivity as our main measure, and use raw and article counts as robustness checks.

\section{Empirical Results}

\section{A. Average Faculty Productivity}

Table 4 reports average individual productivity by university and decade in terms of impact, raw, and article counts for the top 25 schools and others. All non-top 25 universities are clustered into a twenty-sixth university called other. The numbers indicate that faculty members are on average more productive while at the top 25 universities than while at other universities, and the difference in average productivity (shown in the bottom row) grows larger over time. This does not mean, however, that the top 25 universities make individuals more productive. The average productivity levels do not isolate the marginal effect of universities (the university fixed effect) on individuals' productivity above and beyond what the individual brings.

\footnotetext{
${ }^{18}$ Ellison (2002) finds that the number of pages in the average economics article in top tier journals increases by $70-100 \%$ from the mid-1970s through the late 1990s. Consistently, the average article length in our data grows from 10.7 pages in 1970 to 21.9 in 2001, exactly doubling over the three decades.
} 


\section{B. University Fixed Effects Methodology}

To isolate the university fixed effect, we remove the individual characteristics affecting productivity. Then, we control for common factors influencing individual productivity - primarily, experience and position rank. In essence, we view the university fixed effect as that of a treatment; we would like to remove all other factors influencing productivity such that we can compare treatments across universities.

A fairly general representation of the identification of productivity effects is given in (1).

$$
y_{i r f u t}=\theta_{r f u t}+\alpha_{i}+X_{i r t} \beta+\varepsilon_{i r f u t}
$$

The subscripts index individuals $(i: i \in 1, \ldots, 3262)$, position rank ( $r: r \in$ assistant professor, associate professor, full professor, chaired full professor), fields ( $f: f \in$ economics, finance), universities ( $u: u \in\{$ top 25 schools $\}$, others), and years ( $t: t \in$ $1970, \ldots, 2001) . y_{\text {irfut }}$ is the productivity (impact, raw, article) of individual $i$ during year t. $\theta_{\text {rfut }}$ is a general notation for the level effects of rank, field, university, decade, and all of their interactions. In practice, we make some restrictions on the interactions for tractability and describe them in Appendix 1.

The $\alpha_{\mathrm{i}}$ are the individual fixed effects, which are included to control for differences in individual faculty quality. In specifying $\theta_{\text {rfut }}$ and $\alpha_{i}$ as such, we implicitly assume that the individual's fixed effect does not interact with rank, field, or time (or their interactions) in a way that would be systematic to schools.

$\mathrm{X}_{\mathrm{irt}}$ is the matrix of individual control variables, varying over time and representing common factors across faculty which may affect individual productivity irrespective of physical location. These include the number of years elapsed since an individual's first academic appointment (career years), whether or not the individual is a visiting faculty in that year (visiting), and the impact weight of the journal for which the person is currently editing (editor impact).

There is no reason to expect career years to be related linearly to productivity (Oster and Hamermesh, 1998). Given that our primary interest is not in the structural explanation for career years, but in controlling for its relation with productivity, we allow the data to dictate the form of the relation for which we control. A plot of impact 
and raw productivity as a function of career years is shown in Figure 2. In a univariate setting, raw productivity increases for the first few years of an individual's career and then declines, eventually at a declining rate. Impact productivity reaches its peak during the first couple of years and soon thereafter declines monotonically. The figure suggests that productivity is inversely related to age, and that the relation warrants a cubic functional form.

To establish a baseline, we first estimate a model of individual productivity which includes individual fixed effects (to capture the quality of each faculty member); career experience years and stages of career (to control for general productivity trends for all faculty); field effects (to eliminate differences in productivity standards between finance and economics); and decade fixed effects (to control for possible trends in average productivity). We then add the university fixed effects at a decade-field level. The empirical model is given by:

$$
y_{i r f u t}=\theta_{r}+\theta_{f}+\theta_{d}+\theta_{f d}+\theta_{u}+\theta_{f u}+\theta_{u d}+\theta_{f u d}+\alpha_{i}+X_{i r t} \beta+\varepsilon_{i r f u t}
$$

Estimation of (2) allows us to address three key questions. First, are the university fixed effects significant in any statistical and economic way in explaining variation in productivity? As in Bertrand and Scholar (2003), we perform a simple F-test of joint statistical significance of university fixed effects en masse. In our case, this is only the first, but necessary, step. If the university fixed effects are not significant, then any additional tests would be redundant. Even a finding of no fixed effect would be interesting because it would suggest that the research environment has no effect on individual productivity.

If the university fixed effects are significant, it raises another question: what factors drive the university fixed effects? Is it peer pressure, organizational culture, weather, or outside consulting opportunities that drive whether one university is more conducive to research than another? The final question we address is whether university fixed effects vary over time. Hopefully, this should give some insights into the long term sustainability of comparative advantages. 


\section{University Fixed Effects Results}

Table 5 reports the estimates of model (2) for impact productivity (columns 1 and 2), raw productivity (columns 3 and 4), and article count productivity (columns 5 and 6). Article count productivity is estimated with a Poisson model to incorporate the count nature of the data, and thus the coefficient magnitudes cannot be directly compared with the other columns. Columns 2, 4, and 6 include university fixed effects, while columns 1, 3 , and 5 do not.

An initial observation is that the effects of career experience, editorship, and visiting status are not very sensitive to the choice of productivity measure. As already shown in Figure 2, productivity is the highest in early career years. When we use the estimates from columns 1,3 , and 5 to plot productivity over career years, we find that impact productivity is highest during the rookie year. Raw and article count productivities peak between the fourth and sixth year (not coincidentally the time of tenure decision in most places) and drop monotonically afterwards. Age has a particularly large negative influence on impact productivity. Even beyond the effect of rank, a faculty member produces 1.8 fewer impact pages per year after 20 career years, a drop of $44 \%$ from the rookie year (years zero and one). For raw productivity, the inference is a bit smaller: the faculty produces 2.1 raw pages per year less than at the peak, a drop of $15 \%$.

The fact that the impact productivity peaks at the rookie year and declines thereafter provides a possible answer to the puzzle of why schools devote so much energy and resources to recruit rookies when they can hire seasoned junior faculty with proven track records and more polished teaching abilities. The standard answer used to be that rookies have a higher option value. We provide a much simpler explanation: To hire researchers at their peak, the optimal year is the rookie one.

Faculty with higher rank also seem to be less productive. After taking into account career years and individual differences in talent, the marginal impact of being an associate professor is one-half page less impact productivity compared to assistant professors. The marginal impact of being a full professor is almost one page less; for a chaired professor, it is one and one-third pages less. Since we are already controlling for career years, it is impossible to interpret these numbers in a causal way. We are interested in them only as controls and note that all of our results are robust to their omission. 
Accounting for career years and rank, the impact productivity of a chaired professor twenty years after the Ph.D. is $75 \%$ lower than at the beginning of the career. With this result, we are only measuring academic article productivity. Older faculty might produce in other ways, such as with greater administrative service and mentoring of junior faculty and doctoral students.

Editing a journal is not negatively associated with productivity. One possible explanation is that editors are a selected group; only active senior faculty become editors. Hence, the editor variable captures not only the negative effect of the time commitment to editing, but also the positive effect of remaining actively engaged in research despite a relatively senior rank. Alternatively, it is possible that editors have expertise in writing papers suited for the publication process and thus can maintain their productivity level in spite of the time commitment required by the editorship.

The coefficients on the decade dummy variables in columns 1 and 5 show no increase in impact or article count productivities for economics faculty from the 1970s to the 1980s or 1990s. In contrast, the decade coefficients for raw productivity in column 3 are significantly positive. This result is due to the publication inflation inherent in raw productivity described earlier. Hereafter, we rely on the impact productivity to make cross-decades comparisons. The coefficients on the interaction of decades with finance faculty are significantly negative by a similar magnitude across decades, implying that finance faculty are less productive than those in economics departments.

Column 2 adds university fixed effects to the specification. The university fixed effects are estimated at a decade-field level. In other words, we fit 153 fixed effects (26 schools $\mathrm{x} 2$ departments $\mathrm{x} 3$ decades $=156-3$ for the absence of a finance department at Princeton). The F-test for joint significance of the university fixed effects is 35.28 , well above conventional significance thresholds, establishing the relevance of examining university fixed effects. The effects of the control variables on productivity do not materially change with the inclusion of the university fixed effects.

The only coefficients that change markedly are those on the decade dummies. For impact productivity, the decade coefficients for the 1980s and1990s are a significantly positive 0.481 and 1.116 , respectively. One must be careful in interpreting the decade coefficients, as they take on a different interpretation when the university fixed effects are 
included. The offset of the university fixed effects structure is an others university in economics in the 1970s. ${ }^{19}$ The positive decade coefficients imply that a move from one of the top 25 universities to one of the others increases productivity relative to the effect of moving to an other in the 1970s. In other words, the relative fixed effect of other schools has increased by almost one-half an impact-weighted $A E R$ page in the 1980s and by more than one full impact-weighted AER page in the 1990s.

This productivity diffusion from top universities to others over the last two decades can be seen more clearly in panel B of Table 5. It presents the university fixed effects by decades, separately for economics and finance. These coefficients are interpreted as the influence of each of the 25 universities on faculty publications over and above that of the same faculty member when residing at an other university. While the coefficients show that there were 17 and 16 universities with significantly positive effects in the 1970s for economics and finance, respectively, there were only 2 and 4 universities with positive effects by the 1990s. In fact, in the 1990s, nine economics and seven finance departments had negative fixed effects. The declines in the effect of elite universities on productivity can be seen more clearly in Figure 3, which plots the coefficients over time for each university, separately for economics (panel A) and finance (panel B).

Caution should be exercised in interpreting these fixed effects results. Although it may be surprising to see that some of the most elite universities exhibit negative fixed effects, these effects do not mean that the elite universities have less productive faculty members relative to other universities. Because the individual fixed effects are removed, the negative university effects mean that individuals are less productive when residing at that university than at other universities. Our exclusion of book publications and case writing from the productivity measure may also contribute to the negative fixed effects. For example, the Harvard finance group exhibits consistently negative effects throughout the three decades, perhaps because of its emphasis on case writing.

To the extent that trade-offs are made in allocating resources to research versus teaching, our estimate of university fixed effects may bias against schools that emphasize

\footnotetext{
${ }^{19}$ Although the other set of faculty does not represent the universe of faculty at all other universities, the interpretation of the other fixed effect remains valid in that the individual fixed effects have been removed.
} 
teaching. It may be argued that since Business Week began ranking MBA programs in the early 1990s, the top business schools in the U.S. put more emphasis and resources into teaching, thus contributing to the decline in the university effects during the 1990s. Economics departments, however, are not under the same pressure (the US News \& World Report ranking does not put the same emphasis on teaching as does Business Week), and no obvious shift has taken place from research to teaching in economics departments. Thus, our omission of teaching-related activities in measuring productivity is not likely to be responsible for the reduction in the positive effects on research productivity that top universities enjoyed during the 1970s.

\section{Treatment Selection Bias in University Effects Estimation}

A concern with the estimates is that they are subject to a possible treatment selection bias. The location of an individual at any point in time can best be thought of as a two-sided search model, in which the university looks for the best person to fill its needs and the person chooses the best university opportunity that maximizes utility. ${ }^{20}$ Factors important in the utility may include possible productivity spillovers, proximity to one's origin, alma mater, less pressure to produce, etc. Two-sided matching might bias the university fixed effects upwards or downwards, and the bias is likely to depend on a faculty's position. We consider four possible selection bias stories specific to the position of the faculty and the prestige of the university where the faculty might move.

The first source of selection bias arises if our results are driven by full professors moving to lesser schools to quasi-retire. If full professors leave elite schools to other universities with the intent of lowering their effort, the other school fixed effect will be biased downwards.

A second selection story concerns assistant and associate professors who move to less prestigious universities because of a failure to obtain tenure or promotion. It is difficult to predict how individuals' effort levels respond to such moves. One likely story is that the post-move productivity level falls because the faculty has lost some of his intrinsic motivation to do well, thereby biasing downward the university fixed effect for

\footnotetext{
${ }^{20}$ See MacLeod and Parent (1999) and Ackerberg and Botticini (2002) for examples of endogenous matching applications.
} 
the lower-ranked schools. Another possible story is that the pressure for seminal work at the very top schools might be relieved with a move to a lower-ranked school, resulting in higher quantities of publications which would bias the university effect upward for the lower-ranked schools.

The third selection concern arises if universities tend to make offers to people who they consider have good future prospects and if individuals tend to accept offers from universities with a research environment complementary to their needs and attributes. This match is more likely to occur for successful individuals moving to higher ranked or lateral schools, irrespective of position rank. The complementarity would lead to higher productivity in the new location (adjusting for age and career status), generating positive university fixed effects for the elite schools. ${ }^{21}$

Finally, our estimates would be biased if there is an implicit tournament. For example, a tenured faculty at Rochester might continue to work with the goal of making it to Stanford, if she considers Stanford highest in the ladder, while a Stanford person may have no higher career goal to reach (except for the Nobel prize). A tournament bias would result in a negative university fixed effect for the very top schools, as individuals who reach the top fail to sustain the high level of productivity once they arrive.

To assess the magnitude of these potential sources of biases, we construct a transition matrix of changes in productivity around moves as a function of the direction of the move (up, lateral, or down) and as a function of the status of faculty rank (full professor or not). The change in productivity is the average individual-adjusted productivity in the two years after a move minus the average individual-adjusted productivity in the two years before a move. Individual adjusted productivity is defined as the residual of a regression of individual productivity on career years, career years squared, career years cubed, rank, visiting, and editor status. We drop the first year at the new university to account for possible set up costs in moving. An up move is a move

\footnotetext{
${ }^{21}$ The flip side of the complementarity story is that the hiring practices of universities have changed. To explain our results with this story, one would need that the top universities were more effective in hiring in the 1970s than in the 1990s. To test this story, we compare the productivity, adjusted for age and rank, of individuals coming into a school with that of incumbent faculty. Using the average adjusted productivity from the prior two years, we find the same pattern: new hires have higher productivity than incumbents for every decade (0.67 in the 1970s, 1.44 in the $1980 \mathrm{~s}$, and 1.00 in the 1990s). The 1970 's new hire surplus is smaller than that of the 1990s, invalidating this story as a potential explanation for the disappearance of the fixed effect.
} 
from any university that is not in the top 5 to a top 5 institution or from an others university to a top $25 .^{22}$ A down move is any move from a top 5 to a non-top 5 or from a top 25 to others. A lateral move is a move within the top 5, within the top 25 universities, or within the others universities.

The overall results reported in Table 6 do not provide convincing evidence that the declining positive elite university fixed effects are due to any of the four selection biases. We describe evidence concerning each story. When there are hints of legitimacy in the stories, we construct additional tests to ascertain if our results are robust to selection bias.

\section{A. Quasi-retirement Story}

The quasi-retirement selection story predicts negative changes in productivity for full professors moving to lower ranked schools. Although all downward moves of full professors show negative signs, none are significant. Furthermore, the changes in productivity following downward moves are indistinguishable from those following other types of moves by full professors.

\section{B. Non-promoted Moving Down Story}

The second selection story, non-promoted individuals move down and decrease productivity, finds some support from the transition matrix. The downward movement of assistant and associate professors in the 1980s has a negative productivity impact, but the effect is positive and insignificant for the 1970s and 1990s. For this selection story to explain our declining positive university fixed effect, individuals moving down in the 1970s should exhibit more negative productivity shocks than individuals moving down in 1980s. Since this pattern is not observed in the data, the non-promoted moving down story cannot explain our results. Nevertheless, we repeat our main estimation of the university fixed effects while interacting the university fixed effect with faculty rank. The results from this estimation are presented in Appendix 2, which shows diminishing

\footnotetext{
${ }^{22}$ The top five universities are defined to be those on a decade level with the highest average impact productivity for the faculty members as reported in Table 4 separately for finance and economics.
} 
university fixed effects over time for assistant and associate professors as well as for full and chaired professors.

\section{Complementarity Story}

The third selection story also finds only isolated support in the transition matrix. If faculty move to benefit from a particular elite university's complementarity, then we would expect a positive impact for upward or lateral moves irrespective of the faculty rank. Of the twelve relevant combinations of ranks and decades for the lateral and up moves, seven are statistically zero; two are statistically negative; and one is statistically positive. The lone positive impact on productivity occurs for assistant and associate professors moving upward in the 1970s. Notice that the productivity measure already removes the effect of rank and age. Even if the complementarity selection story can explain some of the positive university fixed effects in the 1970s, it cannot explain its disappearance in the 1980s and 1990s without relying on the disappearance of the university fixed effects.

With complementarity, an individual brings something that fits well with the university to generate synergies that result in higher productivity. That is, the complementarity effect contributes to the positive component of a university fixed effect. For example, to explain the disappearance of Harvard economics department's positive

fixed effect in the 1980s and 1990s using the complementarity story, one must argue that while assistant and associate professors in the 1970s were attracted to Harvard with the hope for higher productivity, the new set of professors with similar rank do not have the same motivation to move to Harvard in the 1980s and 1990s. That is, in the 1970s younger faculty expected to enjoy a positive externality from being at Harvard, while in the 1980s and 1990s they did not. But this is tantamount to our hypothesis: During the last three decades big research centers have lost much of their appeal because the externality produced by having high-caliber colleagues has diffused beyond the physical limits of a university. 


\section{Tournament Story}

The final selection story, the tournament story, implies that the impact of up moves, especially for full professors, is negative. Panel A of Table 6 shows that up moves by full professors have statistically zero effects on productivity in the 1970s and the 1980s, but the impact turned negative in the 1990s. The negative result in the 1990s is consistent with a regression to the mean hypothesis. Faculty receiving offers after an exceptional spurt of productivity are unable to sustain the high productivity after the move. However, this theory cannot explain the inter-temporal pattern of our university fixed effects because it is difficult to explain why tournaments appear in the 1990s but not in the 1970s and 1980s.

\section{E. Two-Stage Selection Model}

Nevertheless, to check whether the magnitude of the estimated university fixed effects is biased by endogeneity, we formally address the problem by estimating a treatment model in which the selection into university treatment is not random. The selection model consists of two pieces - estimating the probabilities both of moving and, given a move, of locating to a particular university. We estimate the probability of a move with a logit selection based on age. We then fit McFadden's (1974) conditional logit model to generate predicted probabilities for each individual to be at each location at each point in time. A conditional logit selection specification is a convenient tool when the individual's observed location is the result of a multi-choice problem (Trost and Lee, 1984). After fitting the two logits, we then use the multiplied predicted probabilities as instruments for the university fixed effects indicators in the second stage. The standard errors are corrected for error in the first stage estimation by bootstrapping the logits 500 times in the first stage and adding the variance in the predicted probabilities from the first stage estimates to the regression variance in the second stage following Petrin and Train (2001).

The estimating equations are:

(i)

$$
\begin{gathered}
\text { First Stage }- \text { Probability of moving: } \\
\phi_{i t}^{\text {move }}=\operatorname{logit}[f(\text { age })]
\end{gathered}
$$


(ii) First Stage - Probability of location $=u$ :

$$
\phi_{\text {iut }}^{\text {locate } \mid \text { move }}=\text { conditional logit }\left(Z_{i u t} \eta+v_{i u t}\right)
$$

(iii) Multiplication to obtain predicted probability of being at a location:

$$
\hat{\rho}_{\text {iut }}=\hat{\phi}_{\text {it }}^{\text {move }} * \hat{\phi}_{\text {iut }}^{\text {locate } \mid \text { move }}
$$

(iv) Second stage - Estimation of university effects

$$
y_{\text {irfut }}=\theta_{r}+\theta_{f}+\theta_{d}+\theta_{f d}+\hat{\rho}_{\text {iut }} \theta_{\text {ufd }}^{*}+\alpha_{i}+\mathrm{X}_{i r t} \beta+\varepsilon_{i r f u t}
$$

The goal of the two first stages of the selection model is to obtain $\hat{\rho}_{i u t}$ : the predicted probability of individual $i$ being at university $u$ at time $t$. In (i), we estimate a logit of $\phi_{i t}^{\text {move }}$, the probability that individual $i$ moves in time $t$, as a function of age. In (ii), we refer to each location $u$ as the potential location. $Z_{\text {iut }}$ are the exogenous variables for being at location $u$ specific to individual $i$ at time $t$. Estimating a conditional logit requires that the exogenous variables have some variance across potential locations $u$ in each period for each individual. Equation (iii) is the multiplication of the probability of moving times the conditional probability of a location given a move to arrive at the unconditional probability of being at a location. In the second stage equation (iv), $\theta_{\text {ufd }}^{*}$ is the decadefield university effects based on the instrumented location of each individual. The rest of the second stage equation is the same as in equation (2).

To estimate the propensity to move, we fit a polynomial of the fourth order on the individual's age. Higher orders did not materially increase the LRT test statistic for relevance. Individuals tend to move more in their youth, reflecting a steady increase in the transaction costs to moving as one ages. If individuals have children, their mobility is constrained until children graduate from high school, possibly followed by more freedom to re-locate during late 40's and early 50's. Age is a good exogenous selection variable for moving because it may predict life cycle patterns to moving, but it cannot predict which individuals at a certain age will move to universities for either complementarity or tournament reasons.

Given an estimate of each individual's probability of a move for each year, we then estimate the locational choice part of the selection process. The key to the locational choice estimation is to find good exogenous variables predicting the preference of 
location for each individual. We use four variables. The first is based individuals' preferences for locations close to their origin. Because we cannot obtain city of birth information for our sample, we use the city where their undergraduate university is located as a proxy. The closeness to one's origin is measured by distance in flight times. To create this instrument, we search over 4,000 combinations of flights between cities on expedia.com for mid-week, non-holiday dates. Expedia compares flight times and provides a minimum flight time, simplifying the travel time search information. Our measure, flight times, is the flight time (expressed in 100s of minutes) to the city of origin from the prior-year university minus the flight time to the origin from the potential university. If the difference in flight times is a positive number, reflecting a move closer to home, there should be a higher probability of being in that location.

Another fairly obvious instrument is prior location. Because of transaction costs in moving, the prior year location should have high predictive power for the current location. Using prior location as an instrument should not confound the selection of university with productivity. Consider the individual whose move is undertaken either with the intent to change her own productivity or to match her characteristics better with a potential school. For such an individual, the prior location instrument has no predictive power on potential location.

Because some schools attract back their best former students, our third instrument, $P h D$ School Location, is a dummy variable equal to one if the potential university is the Ph.D. alma mater and the faculty is at one of the top five universities. Universities generally do not hire their own students in the job market, so we set this variable equal to one only if the person has more than two years in career experience.

The fourth instrument is the productivity distance between the individual's prior two years of work and the potential schools' average individual productivity over the same period. Because untenured faculty with below-average productivity can be fired and faculty with above-average productivity can be hired away, we use the absolute value of the difference in productivity to each potential school as the metric for assistant and associate professors. Full professors, unlike their assistant and associate colleagues, cannot be fired but they can be recruited away. Full professors generally are recruited when their productivity is above the recruiting school's average. Therefore, we use the 
unadjusted differences between the individual and the potential school as productivity distance measure for full professors. We also interact productivity distance with each position rank to take full benefit from the varying predictions by rank.

Table 7 presents the selection model estimates of model (3). The first stage estimates are shown in panels A and $\mathrm{B}$. The second stage estimates and the university fixed effects coefficients are in panels $\mathrm{C}$ and $\mathrm{D}$.

The first stage instruments perform very well. In panel A, the LRT test has a statistic of 541.2, indicating a high degree of relevance for age in the probability of a move. Panel B shows that the probability of being at a location increases significantly when individuals move closer to their origin. The probability of being observed at a prior year location is higher, reflecting the strong role of transaction costs to moving. The most successful individuals are more likely to be observed at their Ph.D. locations. The Ph.D. location effect is even stronger for the location choices that are not the prior year location; when individuals move, they are more likely to move to their Ph.D. alma mater. Faculty tend to be at a university with an average productivity similar to their own, regardless of their rank. Overall, our selection model fits the conditional logit model extremely well. With 816,624 observations, the pseudo R-square is 0.821 , and the Wald test statistic is 42,415 .

The second stage estimation in panel $C$ should be compared to column 2 of Table 5, Panel A. We find results very similar to those in Table 5. Career year experience decreases productivity, but the bulk of the effect is loaded on the linear term in the selection model, not on the cubic term previously estimated. Productivity decreases monotonically over rank, but to a slightly lesser degree than the prior estimation.

Turning to the central result of this paper, panel $\mathrm{C}$ documents that the decade effect of other universities, captured in the decade indicator as the offset to the 25 elite universities, exhibits the same positive time trend as observed in the non-selection model. This robustness of the decade effects to the selection model reconfirms our earlier repudiation of the selection stories explaining our results; that is, the dissipation of the university fixed effects cannot be due to selection biases.

Panel D of Table 7 also shows that the positive university fixed effects of elite schools in the 1970s and the 1980s disappeared in the 1990s. The selection model, with 
the bootstrapped standard error correction, increases the errors in estimation rendering many of the estimates insignificant relative to those in Table 5. However, the pattern of diminishing fixed effects for the elite schools is robust: for both economics and finance, we observe a steady decline (increase) in the number of positive (negative) signs over the three decades. We conclude that the dissipation of the university fixed effects in the 1990 s is robust to selection concerns.

\section{Components of University Fixed Effects}

Having established that university fixed effects existed, we attempt to explain what factors determine them, and why they have disappeared. We are particularly interested in the roles of externalities and cultural norms as determinants of these effects.

\section{A. Cross sectional components}

There are two ways to estimate the factors driving the university fixed effects. Method 1 takes the university fixed effects at the decade-field level $\theta_{\text {fud }}$ from Table 5, Panel B and decomposes it into observable determinants:

$$
\theta_{\text {fud }}=\beta_{0 \mathrm{f}}+\mathrm{X}_{\text {fud }}^{\text {dept externalities }} \cdot \beta_{1 \mathrm{f}}+\mathrm{X}_{\text {fud }}^{\text {dept culture }} \cdot \beta_{2 \mathrm{f}}+\mathrm{X}_{\mathrm{u}}^{\text {location }} \cdot \beta_{3 \mathrm{f}}+v_{\text {fud }} \cdot
$$

The advantage of this approach is in its ease of interpretability.

Method 2 inserts the same observable determinants into our original productivity estimating equation (2) and estimates the regression directly using the whole sample. A problem with Method 2 is that it understates the standard errors because the regression is estimated at a person-year level, and most of the regressors change only at a universitydecade level. One of the regressors, the spillover effect from colleagues, is an exception in that it varies by person-year, allowing us to use Method 2 to estimate the impact of the quality of colleagues using the whole sample. Furthermore, this externality changes for each person-year since the average productivity of each person's colleagues is different within the same department and a fortiori over time (e.g., Moretti, 2004). Therefore, to estimate spillover effects, we use Method 2. To estimate the effect of the other observable determinants of the university fixed effect, we use Method 1.

The quality of colleagues can generate positive externalities through the comments of colleagues (Laband and Tollison, 2000) and spillovers from the expertise of 
stars (Goyal et al., 2006; Azoulay and Zivin, 2006). We are interested in if this externality sustained over time. As a measure of quality of colleagues we use, team, the two-year moving average of productivity of all productive members of the department in each year. ${ }^{23}$ We lag the variable one year to remove simultaneity with the productivity dependent variable. We allow the coefficient on team to vary by decade to test whether the externality changes over time. We use the same method as in (2), with impact productivity as the dependent variable, including individual fixed effects, and rather than including the university fixed effects, we include university random effects. Using university random effects, we can identify a team effect, part of whose variation would otherwise be subsumed in the university fixed effects.

The results are presented in Table 8 . The quality of colleagues has a positive and significant effect on productivity during the 1970s and the 1980s, but the effect turns negative in the 1990s. A possible explanation for the negative effect is that being surrounded by highly productive teammates may make a faculty overly cautious and thus less productive. Such an effect might have been in existence in the 1970s and 1980s but was overwhelmed by positive externalities.

Consistent with the fixed effect results, the externality emanating from superior colleagues either disappeared or is diffused beyond the restricted boundaries of the home institution, e.g., to teammates at other universities. If the team effect is solely responsible for the elite university fixed effect, the inclusion of the team variable will eliminate all the positive individual university fixed effects presented in Table 5, panel B. Although not reported in a table, 17(18) of the university fixed effect coefficients are positive and significant for economics (finance) in the 1970s and only 2 (4) are positive and significant for the 1990s. ${ }^{24}$ Although it is possible that our measure of the colleagues externality is not properly captured by team, a more likely explanation is that the effect of highly productive colleagues alone does not fully explain the decrease in the elite university effect.

\footnotetext{
${ }^{23}$ Our definition of non-productive individuals is a person who has not published in the current or prior year. We exclude these individuals because later we want to capture the culture effect through these nonproductive faculty.

${ }^{24}$ Although we employ university random effects to identify the team effect, we switch to a fixed effects specification in order to identify the university fixed effect above and beyond the control for team.
} 
To capture the effect of alternative variables as determinants of the unexplained portion of the university fixed effects, we take the residual university fixed effects after removing the team effect and decompose them on the basis of university characteristics using (4). One characteristic we use is whether a university hosts journal editors or houses a journal. On one hand, editors may share their know-how on crafting papers for publication with their colleagues, and having an in-house editor may favor the editor's colleagues, whose papers might be accepted more easily (e.g, Laband and Piette, 1994b). On the other hand, having in-house editors may have a negative effect if editors delegate more refereeing to colleagues, taking their time away from the production of papers. To explore how these potential impacts play out, we define editors-in-house to be the natural $\log$ of one plus the average number of editors during each decade for the department. We use the natural log because editorship is clustered in a few key schools and the incremental impact may be decreasing.

Another potential source of externality is the average quality of colleagues' training. Faculty quality is measured as the percentage of faculty at a department whose $\mathrm{Ph} . \mathrm{D}$. is obtained from a top five university, where the top five designation is made by ranking average productivity separately for finance and economics by decade.

In addition to externalities captured by team, editors-in-house, and faculty quality, cultural norms may play a role in the university fixed effects. For instance, in elite schools peer pressure to perform might be very strong. Our primary measure of cultural norms is the presence of non-productive colleagues, kindly referred to as deadwood. ${ }^{25}$ Deadwood faculty may have a negative impact on the department's research output by relieving peer pressure to produce and diverting school resources to non-research related activities. ${ }^{26}$ We define deadwood as the percent of faculty who have no publication for two years in a row. Admittedly, this definition is a bit harsh, because the lumpy nature of the publication process might cause very productive faculty to be classified occasionally as deadwood.

\footnotetext{
${ }^{25}$ This variable is in the spirit of a "Bad Apples" variable in the education literature. See Hoxby (2005).

${ }^{26}$ Sacerdote (2001), for example, finds evidence of peer effects on individual outcomes using student living arrangements and subsequent grade performance at Dartmouth. Hoxby (2000) and Angrist and Lang (2004) study peer effects within the classroom.
} 
One may argue that deadwood and team capture the same characteristic of a department, with opposite signs. In fact, the correlation of deadwood and team at the yearly observation level is relatively low at 0.21 . If high team values are driven by a few stars, the relation between team and deadwood would not be automatic. Additionally, deadwood captures the negative research environment that is not measured by a low level of team.

A second measure of cultural norms within the department is measured by the quality of the Ph.D. program. Presumably, a vibrant and successful Ph.D. program reflects the research intensity of the department. However, faculty's research time also may be absorbed by too much interaction with Ph.D. students. We measure Ph.D. quality with the decade average count of students who are hired into in the top 25 schools.

We also control for whether a university is a state school. The public or private nature of the institution might affect financial resources and how they are utilized.

Finally, we want to consider the impact of two environmental variables: the weather and the distance to the closest metropolitan city. The former may influence productivity by affecting the opportunity cost of sitting in the office. We measure weather by the average annual snowfall. Distance may affect both the consulting and the distraction opportunities, but at the same time, it may also help stimulate intellectual curiosity by exposing faculty to topics of current interest in a timely manner. We measure distance as the natural $\log$ of miles to the closest city with more than three-quarters of a million people.

We are not only interested in showing cross-sectional associations between university fixed effects and characteristics of the departments, but also in understanding the negative trend in university fixed effects identified in Table 5. We examine whether this negative trend can be explained by changes in university characteristics over time. Furthermore, the relation between the university fixed effects and certain university characteristics may change over time. We test for this latter possibility by interacting the most important university characteristics with decade dummies. Our focus on the trending aspect of the university fixed effects heightens the concern that an omitted trending factor might bias our coefficients. A Breusch-Pagan test confirms this concern. ${ }^{27}$

\footnotetext{
${ }^{27}$ The test rejects no variance across decades with a $\chi^{2}(1)=4.72$ corresponding to a $p$-value of 0.030 .
} 
Ordinarily, we would add decade fixed effects to resolve this issue. But many of our university characteristics vary only a little over time, so it is difficult to identify both decade fixed effects and university characteristics interacted with a decade dummy. Thus, instead of fitting a model with decade fixed effects, Table 9 presents the results with decade random effects. This is without loss of generality. A Hausman test fails to reject the equality between fixed effects and random effects estimates. ${ }^{28}$

Because the nature of publication productivity may not be the same across fields, we split the decomposition of the university fixed effects into economics (Table 9, columns 1 and 2) and finance (columns 3 and 4). Columns 1 and 3 in Table 9 show that deadwood has a strong and significant negative effect on the university fixed effect. At the bottom of the table, a partial R-square analysis shows that excluding deadwood from the estimating equation lowers the percentage of variation explained by $6 \%$ (from $21 \%$ ) in economics and by $29 \%$ (from $42 \%$ ) in finance. These results indicate that norms play a role in organizational productivity. The magnitude of the coefficients, significance, and partial R-squares are greater in finance than in economics. A possible explanation for this difference is that finance consulting and executive teaching opportunities tend to be more financially rewarding than the policy-related consulting opportunities for most economists.

The existence of in-house editors has a negative sign on the productivity of colleagues in economics and finance, but is significant only for finance. The negative aspects of in-house editorship seem to outweigh the positive ones. The net effect is stronger for finance, perhaps because the burden of having an in-house editor is shared by a larger number of colleagues in economics than in finance.

The percentage of faculty with Ph.D. degrees from top five universities is positively significant for economics and insignificant for finance. The Ph.D. program quality seems to impose more burdens than to provide benefits, but only for economics departments. The proximity to cities, some of which include financial centers, seems to have a positive effect on finance faculty productivity. These three variables, however, do

\footnotetext{
${ }^{28}$ The test rejects fails to reject equivalence of the fixed effects and random effects coefficients with a $\chi^{2}(8)=6.74$ corresponding to a $p$-value of 0.556 .
} 
not explain much of the variation across departments; therefore, we are reluctant to draw definitive inferences based on the regression results.

Being a state school does not seem to have an impact on the university fixed effect. Snowfall is not significant. We expected a positive coefficient in that good weather might make leisure relatively more attractive. The result does not change when we replace snowfall with average January temperatures.

In columns 2 and 4, we allow the effect of deadwood and editors to vary over decades. The effect of deadwood is stable over time, in both economics and finance. The stability of cultural norms suggests that unlike the externality of having productive colleagues, the cultural aspects of institutions do not easily dissipate with technological change. When nonproductive faculty members are protected by the university tenure system, there is no easy cure for a lack of intellectual stimulation, a low motivational work environment, or an overly consulting-oriented environment.

The externality impact of editorship seems to decline, as does the externality of productive colleagues. In economics departments (column 2), the effect of editors begins as positive in the 1970s and becomes insignificant in the 1990s. In finance departments (column 4), in-house editors begins as insignificant in the 1970s and turns negative in the 1990s. Both cases suggest a reduction in the positive externality.

\section{B. Diffusion and Technology Advancements}

We show that the favorable impact on productivity of working at elite universities diminishes since the 1970s. We also show that the importance of colleague externalities vanishes in the 1990s, while the influence of cultural norms remains persistently strong.

To what extent is the progress in information technology responsible for these trends? Technological advancement can facilitate communication and transfer of ideas among co-authors at a distance. It can also facilitate access to knowledge itself, particularly for universities far from the forefront of research. But can we document the magnitude of this effect in practice?

The reduction in the impact of higher-quality colleagues is consistent with the reduction of geographical boundaries through better communication technology. Several papers (Laband and Tollison, 2000; Hamermesh and Oster, 2002; Rosenblat and Mobius, 
2004; Goyal et al., 2006; Azoulay and Zivin, 2006) document dramatic increases in coauthoring at a distance in the latter part of the twentieth century. In particular, Goyal et al. show that the proportion of the economics profession networked through co-authorship has increased from nearly $20 \%$ in the 1970 s to $50 \%$ in the 1990 s. Our additional contribution to this literature is to document that most of the increases in co-authorship took place between elite universities and non-elite ones.

We take the 25,010 author-article observations from the 41 journals with at least one author residing at a top 25 school and weigh each observation with 1/number of authors so that articles will have equal weight. The articles are divided into four types; S $=$ solo articles, $\mathrm{X}=$ co-authored articles with all co-authors within the same school, $\mathrm{Y}=$ co-authored articles with at least one co-author not from the same school but all from a top 25 school, and $Z=$ co-authored articles with at least one co-author outside the top 25 schools. Figure 4 plots the percentage of the four types of papers in our dataset. The results are striking. The percentage of multiple author papers with co-authors from outside the elite schools has steadily increased from about $32 \%$ in the beginning of the 1970 s, nearly doubling to $61 \%$ by 2004 . Papers co-authored with outside authors within the elite schools also increased from $3 \%$ to $9 \%$. These increases contrast sharply with the steady decline in solo authored papers (from $66 \%$ to $24 \%$ ) and essentially no change for in-house co-authored papers (hovering around 6\%). This evidence is consistent with internet and information technology advancements that make access at a distance easier, which disproportionately favors non-elite universities. The advancements in information technology include not only the internet, but also advancements in non-postal delivery systems, such as overnight mail service and fax machines. These earlier developments may explain the graduate increase in co-authorship rather a sudden sharp increase that might be expected if the internet were the only advancement in technology and everyone adopted email use at the same time.

To investigate whether the sharp increase in participation by scholars in non-elite schools is due to an increase in the publication market share of others schools, we compare the percentage of all articles published in the 41 journals with at least one author affiliated with the top 25 schools with the percentage of articles written exclusively by authors in others schools in our dataset. There is no evidence of a change in market share 
between elite and non-elite schools. The percentage of articles with top school participation oscillates between $19 \%$ and $27 \%$, without a discernable trend, and the participation by exclusively non-elite school scholars oscillates between $73 \%$ and $81 \%$. A similar lack of pattern holds when we look at market share weighted by the impact of journals in which the articles were published.

In sum, the available evidence suggests that the reduction in the university fixed effect is due to a diffusion of the externality produced by better colleagues beyond the physical limits of a university.

\section{Impact on Salaries}

Why does it matter that physical location affects productivity? Although the diminishing benefits from physical location have many important implications concerning jobs, outsourcing, migration, regulation, competition policy, education, etc., in this section we focus on its implication to wages, specifically, on the appropriability of the externality. If the externality generated by a better faculty is concentrated within the physical boundaries of a university, the university can capture some of it. In other words, if a faculty member's productivity benefits tremendously from being at Chicago, she might be willing to accept a lower salary to be at Chicago and benefit from this externality. If that externality diminishes, so should the discount in salary. Hence, universities with reductions in their fixed effect should experience higher increases in salaries. In other words, faculty salary should be negatively correlated with changes in the university fixed effects.

Although we are unable to obtain time series data for economics and finance professors salary, the National Center of Education Statistics of the U. S. Department of Education, conducts faculty salary surveys for all the faculties in U.S. colleges and universities on a yearly or biennial basis. The data are compiled into the Higher Education General Information Survey (HEGIS) series for years 1968-1986 and the Integrated Postsecondary Education Data System (IPEDS) series for 1987-2000. The surveys collect salary information by gender, position, and contract length (nine- or tenmonth versus full-year contracts) for faculty in all fields. For comparability across time, 
we take the average salary across gender for nine- or ten-month contracts of assistant, associate, and full professors.

While we do not expect that all departments are affected in the same way by information technology changes, such changes are likely to affect the externalities in the production process of research for a substantial portion of the university faculty. Hence, we examine the relation between salaries and the university fixed effects. To this end, we regress the change in salary (by rank) at each of the twenty-five elite institutions over the three decades on the change in the university fixed effects for economics faculty. We do not include finance because finance faculty enjoyed unusually large salary increases over the past three decades and business schools often have separate budgets which may lead to distinct salary structures.

To equilibrate the quality of the faculty input, we control for the change in the average individual productivity, proxied by the decade-department average of each individual's fixed effects. We fit the estimation in a seemingly unrelated regression (SUR) framework across rank status to account for outside relationships of errors among the ranks.

As predicted, Table 10 reports that changes in the university fixed effects have a negative and statistically significant effect on salary. ${ }^{29}$ This relation is robust across ranks. The results suggest that for each $A E R$ impact page decline in the university fixed effects, assistant professors' salaries increase by $\$ 1,386$; associate professors' by $\$ 1,750$; and full professors' by $\$ 2917 .^{30}$

In sum, the salary evidence is consistent with leading universities becoming relatively less attractive places to work in the last three decades. This salary effect appears to be driven, at least in part, by a reduction in the university fixed effect.

\section{Conclusion}

In this paper we study the nature and the magnitude of production externalities in research at elite U.S. universities. We find strong positive externalities emanating from

\footnotetext{
${ }^{29}$ The observation count of 94 is smaller than the combination of having three ranks, twenty-five schools, and two changes across time because of missing data for Canada and some missing 1970s observations in HEGIS.

${ }^{30}$ The monotonic decline in R-squares, from $6 \%$ for assistant professors to $1 \%$ for full professors, is due partly to the much larger variance in salaries for higher-ranked faculty.
} 
superior colleagues during the 1970s. This effect has disappeared today. The dissipation can be attributed in some part to the diffusion of the externality beyond universities' physical boundaries. An important factor behind this change appears to be the internet revolution, and more generally, advances in information technology. These advances diminish the importance of cooperation within physical boundaries and greatly facilitate collaboration from distance. As a result, there has been a substantial increase in coauthorship between scholars at elite and other universities.

Cultural norms, however, have a persistent effect on production. The presence of non-productive faculty members, a proxy for a low motivational work environment, has a strong negative impact on the productivity of the other faculty members. The bad influence of non-productive colleagues seems to extend well beyond the opportunity cost of positions occupied by unproductive employees.

The disappearance of positive university fixed effects suggests that, as far as research productivity is concerned, elite universities are indeed losing their competitive edge. Because of the reduced importance of personal interactions, one traditional advantage of elite universities - to act as a focal point attracting the smartest faculty - is at risk. Furthermore, the negative relation between changes in university fixed effects and salary changes suggests that elite universities with low externalities are no longer able to retain star faculty on the strength of their reputation alone. Upcoming universities now compete on a more level playing field to attract productive faculty.

These results have implications for knowledge-based industries. An increasing fraction of production in developed countries consists of research-like products. If, as our evidence suggests, the physical location of production is less important today for these products, the nature of these firms and the way they should be managed is fundamentally changed. When physical proximity is required for externality, firms exercise authority over their employees by controlling access to the physical premises (Rajan and Zingales, 1998, 2001). As a result, our findings suggest that in knowledge-based industries, the boundaries of firms are becoming fuzzier. Through technological advancement these industries are losing a powerful instrument to regulate and control the accumulation and utilization of knowledge. As a consequence, appropriating returns to investment in research and development will become more difficult, tilting the playing field in favor of 
the key generators of knowledge and holders of property rights, i.e., superstar researchers and knowledge coordinators. ${ }^{31}$

The implication of fuzzier firm boundaries goes beyond industries that specialize in research-like products. Disruptions will, of course, vary across type of industry. When economies of scale and physical interactions are important as in traditional manufacturing, the pace and scope of transformation will be curtailed. However, industries that rely heavily on human capital and expertise, such as financial services and entertainment, may find centralizing their production in core locations, such as New York and Hollywood, to be increasingly less important. What we have documented for universities has also been happening in other industries. Back office operations are increasingly outsourced overseas. Industries that can provide service over the internet (e.g., real estate brokering) are breaking out of traditional modes of operation. Our results suggest that these breakdowns are only the tip of the iceberg; in the not-so-distant future, many industries may find little need for locational anchors at all.

At the macro level, our results suggest that countries leading in technology may find it difficult to sustain their competitive advantage. Advances in information technology facilitate easier, low cost access to the technological frontier for researchers and knowledge coordinators worldwide, providing them an opportunity to challenge the leadership roles in knowledge-based industries in a relatively short span of time.

\footnotetext{
${ }^{31}$ This might explain the surge in the return to human capital in the top $0.1 \%$ of the income distribution documented by Saez (2006).
} 


\section{Appendix 1}

We discuss the restrictions on $\theta_{\text {rfut }}$ necessary to identify the model. At the risk of being over-conservative, we begin with the full expansion of $\theta_{\text {rfut: }}$ :

$$
\theta_{\text {rfut }}=\theta_{\mathrm{r}}+\theta_{\mathrm{f}}+\theta_{\mathrm{u}}+\theta_{\mathrm{t}}+\theta_{\mathrm{rf}}+\theta_{\mathrm{ru}}+\theta_{\mathrm{rt}}+\theta_{\mathrm{fu}}+\theta_{\mathrm{ft}}+\theta_{\mathrm{ut}}+\theta_{\mathrm{rfu}}+\theta_{\mathrm{rft}}+\theta_{\mathrm{rut}}+\theta_{\text {fut }}+\theta_{\text {rfut }}
$$

The key effect in which we are interested is the effect of university departments on productivity over time, $\theta_{\text {fut }}$.

Since faculty rosters are not sufficiently large to estimate the university effect at the year level (and productivity is noisy even at a year level as the fruits of research do not flow consistently), we focus on the decade ( $d$ : $d \in 1970 \mathrm{~s}, 1980 \mathrm{~s}, 1990 \mathrm{~s}$ including 2000-2001) rather than year effect of universities. So we begin by imposing:

$$
\begin{aligned}
& \text { R.1: } \theta_{\mathrm{t}}=\theta_{\mathrm{d}} \\
& \text { R.2: } \theta_{\mathrm{ft}}=\theta_{\mathrm{fd}}
\end{aligned}
$$

From our analysis of "inflation", we have determined that a page of impact productivity should roughly be the same across time. Thus, any systematic time effect captured in $\theta_{\mathrm{t}}$ should be sufficiently small that measuring it at a decade level (rather than at a year level) should be inconsequential. R.2 requires that this assumption holds within each subfield (economics and finance). ${ }^{32}$

Building on R.1 and R.2, we impose that any university effect, field effect, or university field effect that varies over time can be measured at a decade level without inducing a bias in $\theta_{\text {fud: }}$

$$
\begin{aligned}
& \text { R.3.: } \theta_{\text {ut }}=\theta_{\text {ud }} \\
& \text { R.4.: } \theta_{\text {fut }}=\theta_{\text {fud }}
\end{aligned}
$$

For a bias to exist, it must be either that the step pattern of applying a decade restriction is correlated with another variable which does exhibit lumpy changes or that the ad-hoc slicing of time at the calendar decade end impacts estimation because university effects are non-monotonic. For example, say a department effect is constant for 1970-1974, improves from 1975-1984 and declines from 1985-1989. A decade study might miss

\footnotetext{
32 This assumption is needed in spite of R1 because the year effects for finance and economics could offset each other within decades.
} 
such effect. However, in our defense, the pattern of university impacts is likely to be a slow-moving monotonic trend since the effect of any individual is removed from the analysis. Nevertheless, to ensure that our results are robust to this assumption, we also estimate a model that allows the university field effect to trend over time.

The remaining restrictions ensure that our estimated university effects are not driven by a changing effect of rank over time (R.5-R.7), across fields (R.8-R.9), or across time-fields (R.10).

$$
\begin{aligned}
& \text { R.5.: } \theta_{\mathrm{rf}}=0 \\
& \text { R.6.: } \theta_{\mathrm{rt}}=0 \\
& \text { R.7.: } \theta_{\mathrm{rft}}=0
\end{aligned}
$$

Since the procedures embedded in the tenure system are universal across fields, there would be no reason to expect the rank effect to vary by field. R.5. is easy to test. As in R.5., the restriction of no changing rank effect over time (R.6.) is a facet of the static nature of the tenure system. Thus, we would not expect the rank effect to vary over time. R.7 becomes innocuous after assuming R.5 and R. 6 and accepting that there would be no reason for rank effects not to vary over time or over fields but to have a non-zero fieldtime covariance.

$$
\begin{aligned}
& \text { R.8.: } \theta_{\mathrm{ru}}=0 \\
& \text { R.9.: } \theta_{\mathrm{rfu}}=0
\end{aligned}
$$

R.8. restricts rank effects to be the same across schools. In robustness checks, we allow rank effects to vary by school. R.9 adds that, given that we are allowing university effects to vary over schools, any variation does not depend on rank. Beyond the effect of varying rank effects across schools captured in the two-way interaction in R.8, R.9 is unlikely to be violated except in cases in which the standards for an economics department are widely different from those of a finance department within a school.

$$
\text { R.10: } \theta_{\text {rut }}=0
$$

We would like to be able to conduct our analysis allowing the university effect over time to vary across schools and across school ranks within each school. The number of faculty in assistant and associate positions who move within a decade is, however, not sufficiently large to estimate a university-rank effect even by decade. Because it is plausible that a university pattern which we encounter is driven by a time pattern in the 
effect of rank pressures varying across schools, we repeat all of our results for a breakdown of full professors versus those still seeking some level of promotion.

Finally, the 4-way interaction $\theta_{\text {rfut }}$ becomes innocuous since we are interested in analyzing an interaction at a lower level of aggregation. Any possible bias in our estimates can only come from the failure of one of the 2-way or 3-way restrictions discussed above. 


\section{References}

Ackerberg, Daniel A., and Maristella Botticini. "Endogenous Matching and the Empirical Determinants of Contract Form." Journal of Political Economy 110, no. 3 (2002): 564-91.

Alexander, Jr., John C., and Rodney H. Mabry. "Relative Significance of Journals, Authors and Articles Cited in Financial Research." Journal of Finance 49, no. 2 (1994): 697-712.

Angrist, Joshua D., and Kevin Lang. "Does School Integration Generate Peer Effects? Evidence from Boston's Metco Program." American Economic Review 94, no. 5 (2004): 613-1634.

Arnold, Tom, Alexander W. Butler, Timothy F. Crack, and Altintig Altintig. "Impact: What Influences Finance Research?" Journal of Business 76, no. 2 (2003): 343-61.

Azoulay, Pierre, and Joshua Graff Zivin. "Peer Effects in the Workplace: Evidence from Professional Transitions for the Superstars of Medicine." Columbia University Working Paper (2005).

Bertrand, Marianne, and Antoinette Scholar. "Managing with Style: The Effect of Managers on Firm Policies." Quarterly Journal of Economics 118, no. 4 (2003): 1169208.

Blair, Dudley W., Rex L. Cottle, and Myles S. Wallace. "Faculty Ratings of Major Economics Departments by Citations - an Extension." American Economic Review 76, no. 1 (1986): 264-67.

Borokhovich, Kenneth A., Robert J. Bricker, Kelly R. Brunarski, and Betty J. Simkins. "Finance Research Productivity and Influence." Journal of Finance 50, no. 5 (1995): 1691-717.

Chan, Kam C., Carl R. Chen, and Thomas L. Steiner. "Production in the Finance Literature, Institutional Reputation, and Labor Mobility in Academia: A Global Perspective." Financial Management 31, no. 4 (2002): 131-56.

Conroy, M. E., R. Dusansky, D. Drukker, and A. Kildegaard. "The Productivity of Economics Departments in the Us: Publications in the Core Journals." Journal of Economic Literature 33, no. 4 (1995): 1966-71.

Davis, Paul, and Gustav F. Papanek. "Faculty Ratings of Major Economics Departments by Citation." American Economic Review 74, no. 1 (1984): 225-30.

de Borda, Jean-Charles. "Mémoire Sur Les Élections Au Scrutin." In Histoire De L'académie Royale Des Sciences. Paris, 1781. 
Dusansky, Richard, and Clayton J. Vernon. "Rankings of U.S. Economics Departments." Journal of Economic Perspectives 12, no. 1 (1998): 157-70.

Ellison, Glenn. "The Slowdown of the Economics Publishing Process." Journal of Political Economy 110, no. 5 (2002): 947-93.

Goyal, Sanjeev, Marco J. Van Der Leij, and Jose-Luis Moraga. "Economics: An Emerging Small World?" Journal of Political Economy forthcoming (2006).

Graves, Philip E., James R. Marchand, and Randall Thompson. "Economics Department Rankings: Research Incentives, Constraints and Efficiency." American Economic Review 72, no. 5 (1982): 1131-41.

Hamermesh, Daniel S., and Sharon M. Oster. "Tools or Toys? The Impact of High Technology on Scholarly Productivity." Economic Inquiry 40, no. 4 (2002): 539-55.

Heck, J. Louis, Philip L. Cooley, and Carl M. Hubbard. "Contributing Authors and Institutions to the Journal of Finance: 1946-1985." Journal of Finance 41, no. 5 (1986): 1129-40.

Hoxby, Caroline M. "Peer Effects in the Classroom: Learning from Gender and Race Variation." NBER Working Paper 7867 (2000).

Hoxby, Caroline M., and Gretchen Weingarth. "Taking Race out of the Equation: School Reassignment and the Structure of Peer Effects." Harvard University Working Paper (2005).

Kaufman, George G. "Rankings of Finance Departments by Faculty Representation on Editorial Boards of Professional Journals: A Note." Journal of Finance 39, no. 4 (1984): 1189-97.

Klemkosky, Robert C., and Donald L. Tuttle. "Institutional Source and Concentration of Financial Research." Journal of Finance 32, no. 3 (1977): 901-07.

Laband, David N., and Michael J. Piette. "The Relative Impacts of Economics Journals 1970-1990." Journal of Economic Literature 32, no. 2 (1994): 640-66.

Laband, David N., and Robert D. Tollison. "Intellectual Collaboration." Journal of Political Economy 108, no. 3 (2000): 632-62.

Levin, Jonathan. "Multilateral Contracting and the Employment Relationship." Quarterly Journal of Economics 117, no. 3 (2002): 1075-103.

Liebowitz, Stanley J., and John P. Palmer. "Assesing the Relative Impacts of Economics Journals." Journal of Economic Literature 22, no. 1 (1984): 77-88. 
Liner, Gaines H. "Core Journals in Economics." Economic Inquiry 40, no. 1 (2002): 13845.

MacLeod, W. Bentley, and Daniel Parent. "Job Characteristics and the Form of Compensation." In Research in Labor Economics, edited by Solomon W. Polachek, 177242. Stamford, CT: JAI Press, 1999.

McFadden, Daniel. "Coonditional Logit Analysis of Qualitative Choice Behavior." In Frontiers in Econometrics, edited by P. Zarembka, 105-42. New York: Academic Press, 1974.

Moretti, Enrico. "Workers' Education, Spillovers, and Productivity: Evidence from PlantLevel Production Functions." American Economic Review 94, no. 3 (2004): 565-690.

Niemi, Jr., Albert W. "Institutional Contributions to the Leading Finance Journals, 1975 through 1986: A Note." Journal of Finance 42, no. 5 (1987): 1389-97.

Oster, Sharon M., and Daniel S. Hamermesh. "Aging and Productivity among Economists." Review of Economics and Statistics 80, no. 1 (1998): 154-56.

Petrin, Amil, and Kenneth Train. "Omitted Product Attributes in Discrete Choice Models." University of California at Berkeley Working Paper (2002).

Rajan, Raghuram G., and Luigi Zingales. "Power in a Theory of the Firm." Quarterly Journal of Economics 113, no. 3 (1998): 387-432.

- "The Firm as a Dedicated Hierarchy: A Theory of the Origins and Growth of Firms." Quarterly Journal of Economics 116, no. 3 (2001): 805-52.

Rosenblat, Tanya S., and Markus M. Mobius. "Getting Closer or Drifting Apart." Quarterly Journal of Economics 119, no. 3 (2004): 971 - 1009.

Sacerdote, Bruce. "Peer Effects with Random Assignment: Results for Dartmouth Roommates." Quarterly Journal of Economics 116, no. 2 (2001): 681-704.

Saez, Emmanuel, and Thomas Piketty. "The Evolution of Top Incomes: A Historical and International Perspective." American Economic Review 96, no. 2 (2006): forthcoming.

Sauer, Raymond D. "Estimates of the Returns to Quality and Coauthorship in Economic Academia." Journal of Political Economy 96, no. 4 (1988): 855-66.

Scott, Loren C., and Peter M. Mitias. "Trends in Ranking of Economics Departments in the U.S.: An Update." Economic Inquiry 34 (1996): 378-400. 
Trost, Robert P., and Lung-Fei Lee. "Technical Training and Earnings: A Polychotomous Choice Model with Selectivity." Review of Economics and Statistics 66, no. 1 (1984): 151-56.

White, Halbert. "Nonlinear Regression on Cross-Section Data." Econometrica 48, no. 3 (1980): 721-47. 
Panel A: Review of Economic Studies

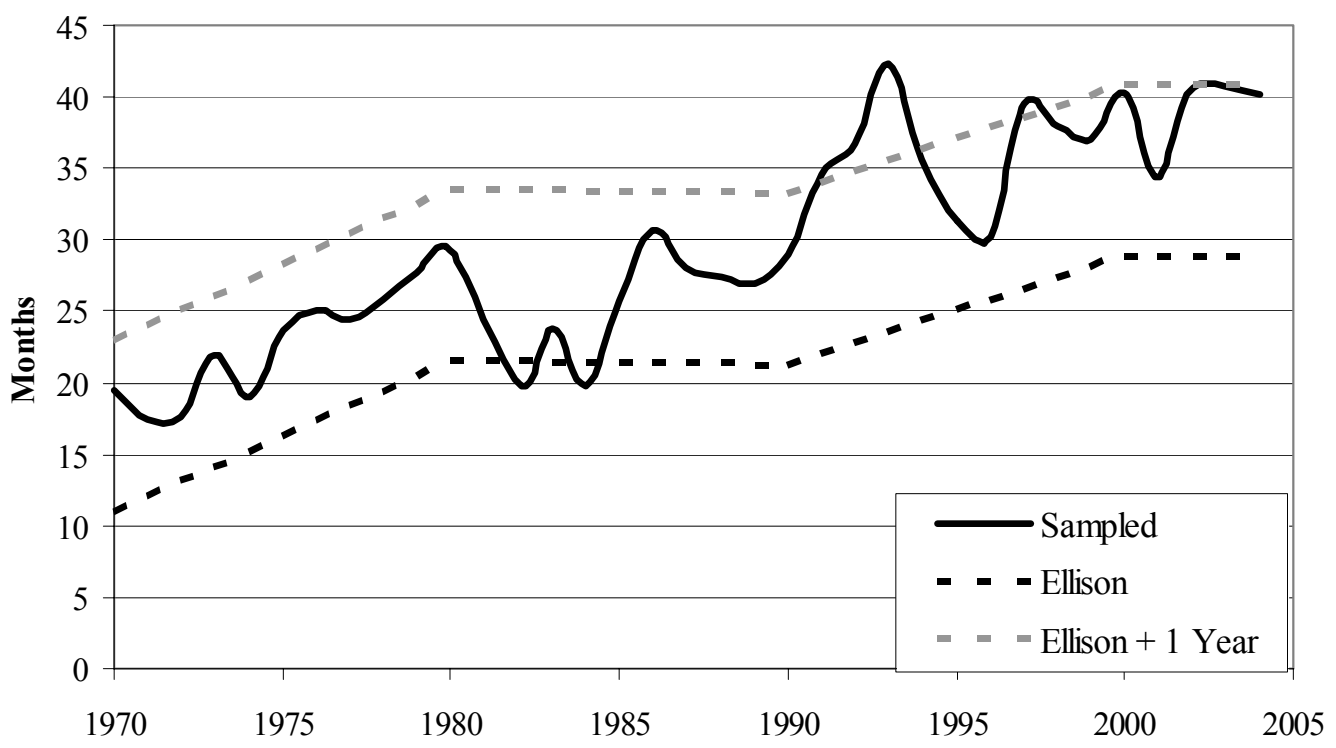

Panel B: Journal of Financial Economics

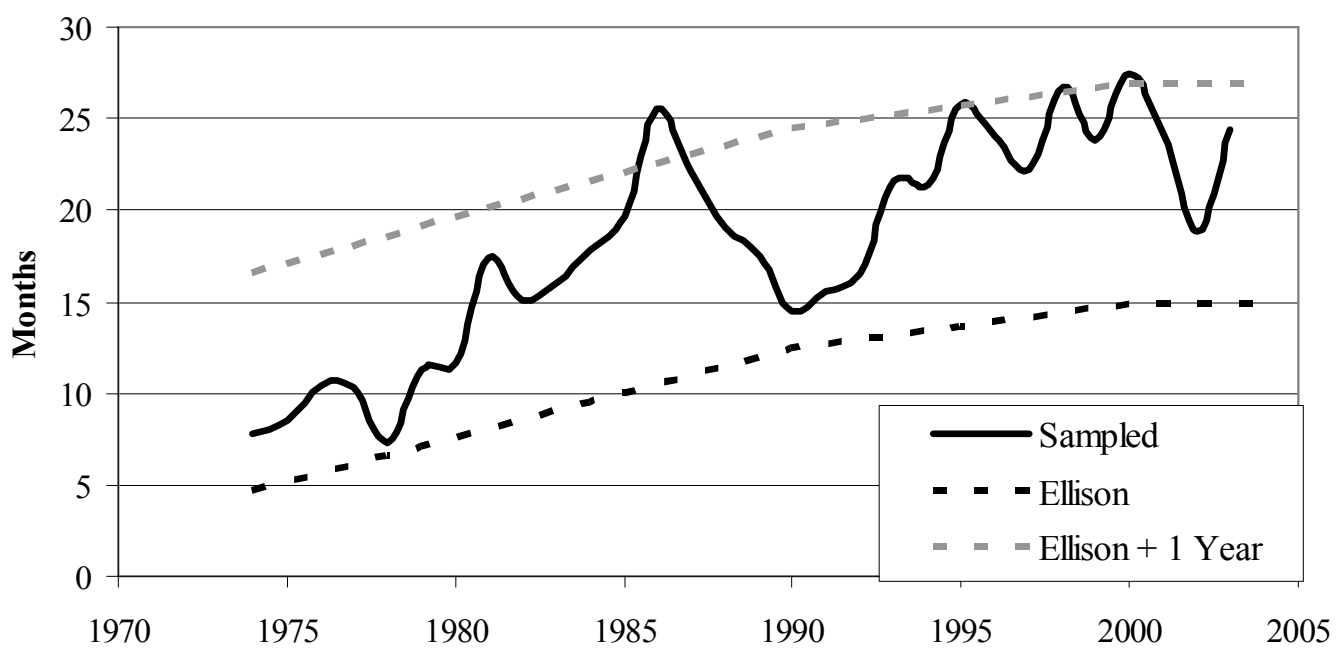

Figure 1: Journal-Specific Time Lags in the Writing to Publication Process

Time from writing a paper to publication in a journal consist of three parts - time from the project commencement to journal submission, time from journal submission to acceptance, and time from acceptance to publication. The Sampled solid line is the time in months from submission to publication for publications in the Review of Economic Studies (Panel A) and Journal of Financial Economics (Panel B) from an average of 15 articles per year for 1970-2002. The Ellison dashed black line is the interpolated decade-average time from submission to acceptance for these journals as reported in Ellison (2002). The Ellison +1 Year dashed grey line represents a one year addition to Ellison to account for the time from the midpoint in writing the paper to submission plus the time from acceptance to publication. 


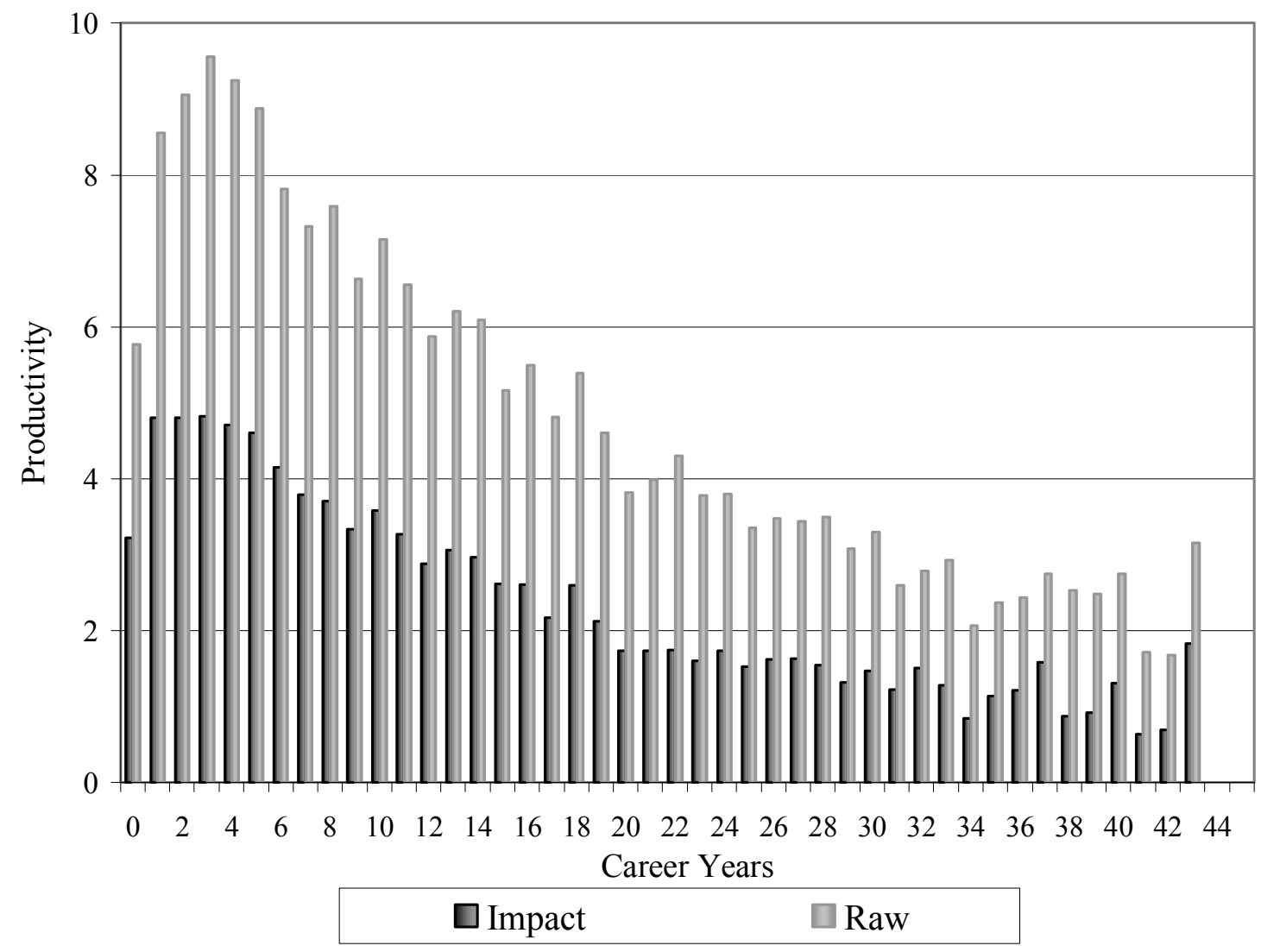

Figure 2: Average Individual Annual Productivity by Career Years

An individual's raw productivity is measured as the AER equivalent pages for that person for the year in which the article productivity was written, using the Ellison adjustment plus one year to lag from the publication dates of articles to the writing time period. Career years is the number of years since the faculty's Ph.D. year. If the person has not yet received his/her Ph.D., career years is recorded at zero. 


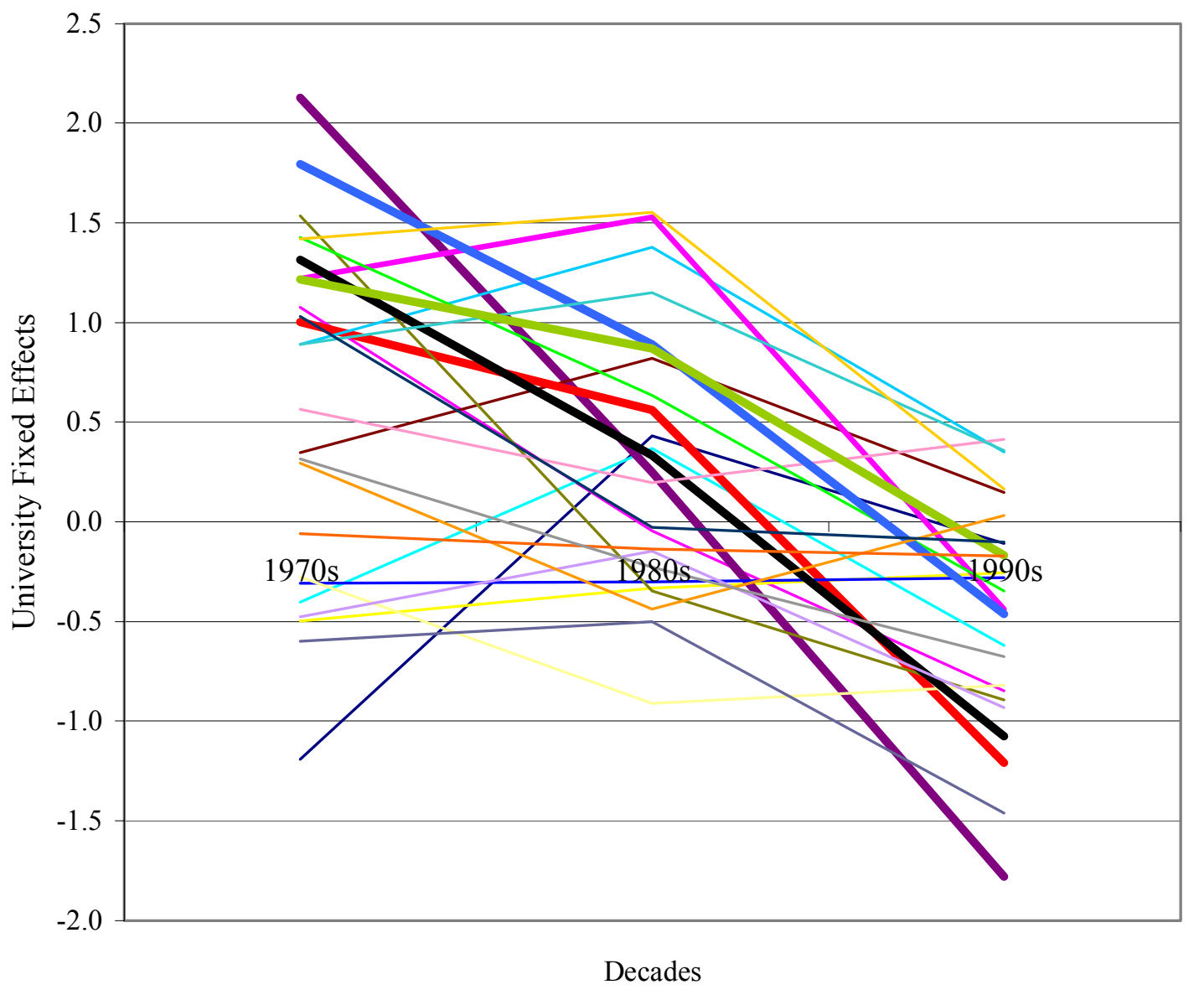

\begin{tabular}{|lllll|}
\hline Carnegie & - Columbia & Cornell & - Duke & Harvard \\
\cline { 2 - 3 } Indiana & MIT & - NYU & - Northwestern & Ohio State \\
Princeton & Purdue & Stanford & - UBC & Berkeley \\
UCLA & Chicago & - Michigan & Penn & Rochester \\
USC & - Texas & - Washington & - Wisconsin & - Yale \\
\hline
\end{tabular}

\section{Figure 3, Panel A: University Fixed Effects over Decades for Economics Departments}

University fixed effects coefficients are taken from the $2^{\text {nd }}$ column estimation of Table 5, panel A, with values corresponding to Table 5, panel $\mathrm{B}$, columns 1-3. 


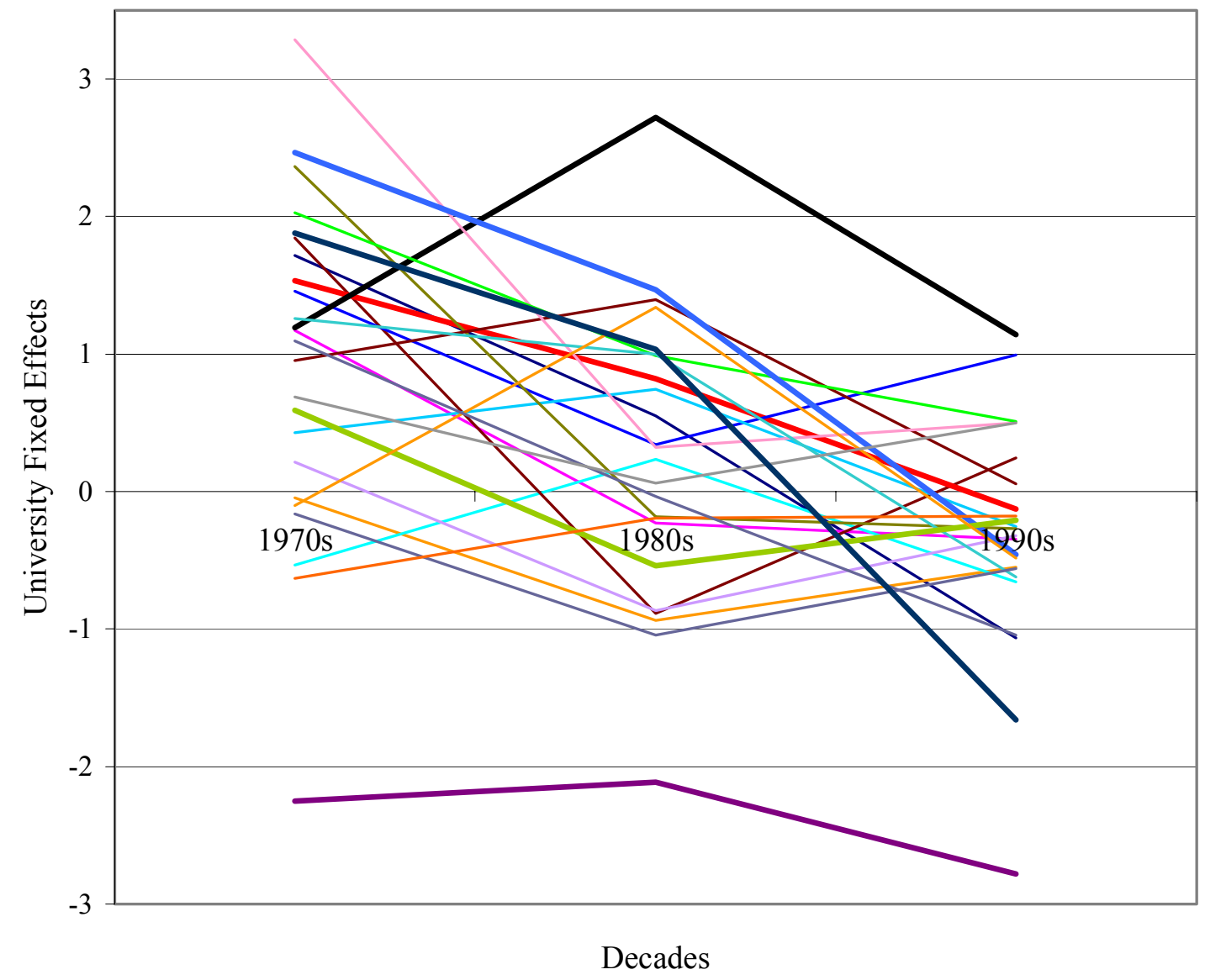

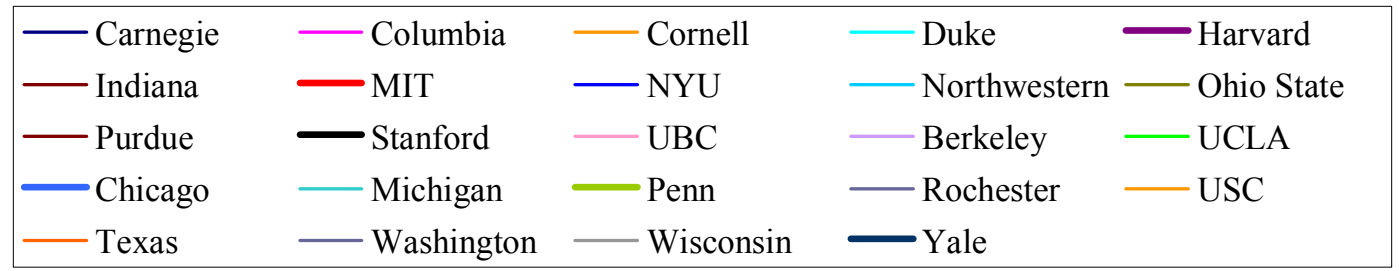

Figure 3, Panel B: University Fixed Effects over Decades for Finance Departments

University fixed effects coefficients are taken from the $2^{\text {nd }}$ column estimation of Table 5, panel A, with values corresponding to Table 5, panel $\mathrm{B}$, columns 4-6 


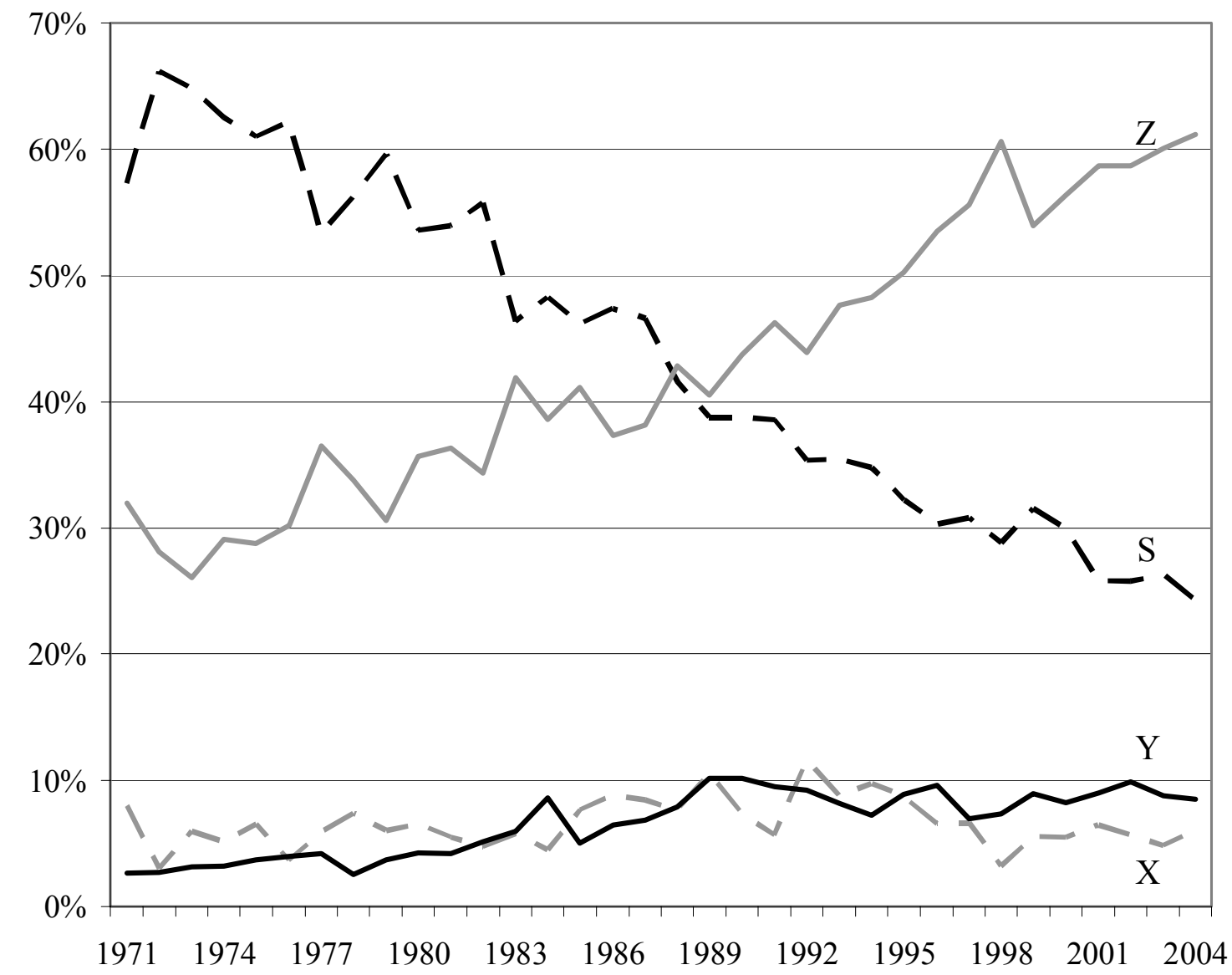

\begin{tabular}{|c|c|}
\hline $\begin{array}{l}- \text { Solo } \\
\text { - Multi-Authored In Ton } 25\end{array}$ & $\begin{array}{l}- \text { - Multi-Authored In-House } \\
\\
\text { Multi-Authored with Non-Ton } 25\end{array}$ \\
\hline
\end{tabular}

Figure 4: Patterns in Co-Authorship

For all articles published in the top 41 journals with at least one author residing at a top 25 school, presented are the percentages of articles falling into one of four types: $s=$ solo articles (black dotted line), $x$ $=$ co-authored articles with all co-authors within the same school (black solid line), $\mathrm{y}=$ co-authored articles with at least one outside co-author but within the top 25 schools (grey dotted line), and $\mathrm{z}=$ co-authored articles with at least one outside co-author outside of the top 25 schools (grey solid line). 
Table 1, Panel A: Studies Ranking University Research

\begin{tabular}{|c|c|c|c|}
\hline Study & Field & Sub-Period & Methodology \\
\hline $\begin{array}{l}\text { Graves et al. } \\
\text { American Economic } \\
\text { Review (1982) }\end{array}$ & Economics & 1974-1978 & Calculates $A E R$ equivalent pages. \\
\hline $\begin{array}{l}\text { Davis and Papanek } \\
\text { American Economic } \\
\text { Review (1984) }\end{array}$ & Economics & $1978-1981$ & Counts average number of citations in SSCI. \\
\hline $\begin{array}{l}\text { National Research Council } \\
\text { (1983) }\end{array}$ & Economics & 1983 & $\begin{array}{l}\text { Employs methodology based on subjective } \\
\text { evaluation of raters plus considerations of an } \\
\text { institution's graduates, library, R\&D budget, } \\
\text { and program and faculty output. }\end{array}$ \\
\hline $\begin{array}{l}\text { Scott and Mitias } \\
\text { Economic Inquiry (1996) }\end{array}$ & Economics & 1984-1993 & $\begin{array}{l}\text { Calculates AER equivalents pages. Divides } \\
\text { by number of coauthors. }\end{array}$ \\
\hline $\begin{array}{l}\text { Dusansky and Vernon } \\
\text { Journal of Economic } \\
\text { Perspectives (1998) }\end{array}$ & Economics & 1990-1994 & $\begin{array}{l}\text { Weights AER pages by Laband-Piette (1994) } \\
\text { impact factor. Divides by number of } \\
\text { coauthors. }\end{array}$ \\
\hline $\begin{array}{l}\text { Coupe Revealed } \\
\text { Performance Website: } \\
\text { http://student.ulb.ac.be/ /tc } \\
\text { oupe/ranking.html }\end{array}$ & Economics & 1994-1998 & $\begin{array}{l}\text { Calculates impact factor (citations/ } \\
\text { \#articles) for each journal. Divides by } \\
\text { number of coauthors. }\end{array}$ \\
\hline $\begin{array}{l}\text { Coupe Revealed } \\
\text { Performance Website: } \\
\text { http://student.ulb.ac.be/ tc } \\
\text { oupe/ranking.html }\end{array}$ & Economics & $1998-2001$ & $\begin{array}{l}\text { Uses top } 10 \text { journals of KMS (1999). Uses } \\
\text { Laband Piette (1994) long-term impact } \\
\text { factor. Divides by coauthors. }\end{array}$ \\
\hline $\begin{array}{l}\text { Klemkosky \& Tuttle } \\
\text { Journal of Finance (1977) }\end{array}$ & Finance & $1966-1975$ & $\begin{array}{l}\text { Chooses all articles in primary finance } \\
\text { journals and articles in secondary list that } \\
\text { meet the criterion: "Would the JF or JFQA } \\
\text { consider this article or note suitable for } \\
\text { publication in terms of subject matter?" } \\
\text { Counts pages. Divides by number of co- } \\
\text { authors. }\end{array}$ \\
\hline $\begin{array}{l}\text { Niemi } \\
\text { Journal of Finance }(1987)\end{array}$ & Finance & $1975-1986$ & $\begin{array}{l}\text { Counts number of pages for articles. Divides } \\
\text { by number of co-authors. }\end{array}$ \\
\hline $\begin{array}{l}\text { Borokhovich et al. } \\
\text { Journal of Finance (1995) }\end{array}$ & Finance & $1989-1993$ & $\begin{array}{l}\text { Weights pages by journal impact factor } \\
\text { constructed with the number of citations for } \\
\text { the journal. Divides by number of co- } \\
\text { authors. }\end{array}$ \\
\hline $\begin{array}{l}\text { Chan, Chin and Steiner } \\
\text { Financial Management } \\
\text { (2002) }\end{array}$ & Finance & $1996-2001$ & $\begin{array}{l}\text { Converts pages to JF page equivalents. } \\
\text { Divides by number of co-authors. }\end{array}$ \\
\hline
\end{tabular}


Table 1, Panel B: Research Rankings of Universities

\begin{tabular}{|c|c|c|}
\hline Rank & University & Borda Count Score \\
\hline 1 & University of Chicago & 17.74 \\
\hline 2 & University of Pennsylvania & 17.19 \\
\hline 3 & Harvard University & 16.94 \\
\hline 4 & New York University & 13.05 \\
\hline 5 & Massachusetts Institute of Technology & 12.98 \\
\hline 6 & Stanford University & 12.89 \\
\hline 7 & Northwestern University & 11.83 \\
\hline 8 & University of California at Los Angeles & 11.70 \\
\hline 9 & University of Michigan & 10.54 \\
\hline 10 & Columbia University & 9.10 \\
\hline 11 & University of Rochester & 7.74 \\
\hline 12 & University of California at Berkeley & 7.59 \\
\hline 13 & Yale University & 6.78 \\
\hline 14 & Princeton University & 6.20 \\
\hline 15 & Ohio State University & 5.60 \\
\hline 16 & Cornell University & 5.36 \\
\hline 17 & University of Wisconsin & 5.32 \\
\hline 18 & Duke University & 4.63 \\
\hline 19 & University of British Columbia & 2.39 \\
\hline 20 & Purdue University & 2.28 \\
\hline 21 & University of Washington & 2.13 \\
\hline 22 & Indiana University & 1.91 \\
\hline 23 & University of Texas at Austin & 1.81 \\
\hline 24 & Carnegie-Mellon University & 1.79 \\
\hline 25 & University of Southern California & 1.71 \\
\hline 26 & Boston University & 1.42 \\
\hline 27 & University of Illinois & 1.36 \\
\hline 28 & University of California at San Diego & 1.33 \\
\hline 29 & University of Minnesota & 1.18 \\
\hline 30 & University of Maryland & 0.98 \\
\hline 31 & Johns Hopkins & 0.63 \\
\hline 32 & London School of Business & 0.63 \\
\hline 33 & Rutgers University & 0.63 \\
\hline 34 & Boston College & 0.51 \\
\hline 35 & University of Pittsburgh & 0.50 \\
\hline 36 & London School of Economics & 0.43 \\
\hline 37 & University of North Carolina & 0.42 \\
\hline 38 & Louisiana State University & 0.27 \\
\hline 39 & Virginia Polytechnique University & 0.22 \\
\hline 40 & University of Iowa & 0.21 \\
\hline 41 & University of Toronto & 0.20 \\
\hline 42 & Hong Kong Polytechnique University & 0.18 \\
\hline 43 & Brown University & 0.17 \\
\hline 44 & Oxford University & 0.13 \\
\hline 45 & California Institute of Technology & 0.10 \\
\hline 46 & University of Virginia & 0.08 \\
\hline
\end{tabular}


Table 2: Impact Factors and Decade Impact Rankings

\begin{tabular}{|c|c|c|c|c|c|c|}
\hline \multirow{3}{*}{$\begin{array}{c}\text { Journal } \\
\text { (Ordered by } 1970 \text { Rank) }\end{array}$} & \multicolumn{2}{|c|}{ 1970s } & \multicolumn{2}{|c|}{ 1980s } & \multicolumn{2}{|c|}{ 1990s } \\
\hline & Impact & & Impact & & Impact & \\
\hline & Factor & Rank & Factor & Rank & Factor & Rank \\
\hline American Economic Review & 1.00 & $(1)$ & 1.00 & $(2)$ & 1.00 & (1) \\
\hline Journal of Political Economy & 0.93 & (2) & 0.75 & (4) & 0.72 & (5) \\
\hline Journal of Financial Economics & 0.85 & (3) & 1.04 & (1) & 0.88 & (3) \\
\hline Review of Economics and Statistics & 0.74 & (4) & 0.43 & (11) & 0.51 & (7) \\
\hline Econometrica & 0.71 & (5) & 0.89 & (3) & 0.49 & (8) \\
\hline Review of Economic Studies & 0.69 & (6) & 0.59 & (9) & 0.67 & (6) \\
\hline Rand Journal of Economics \Bell & 0.61 & (7) & 0.66 & (6) & 0.41 & (9) \\
\hline Journal of Finance & 0.60 & (8) & 0.60 & (8) & 0.96 & (2) \\
\hline Journal of Monetary Economics & 0.58 & (9) & 0.75 & $(5)$ & 0.37 & (11) \\
\hline International Economic Review & 0.49 & (10) & 0.27 & (22) & 0.33 & (16) \\
\hline Quarterly Journal of Economics & 0.43 & (11) & 0.62 & (7) & 0.80 & (4) \\
\hline Journal of American Statistical Association & 0.43 & (12) & 0.37 & (14) & 0.34 & (15) \\
\hline Journal of Economic Theory & 0.43 & (13) & 0.37 & (15) & 0.17 & (29) \\
\hline Journal of Public Economics & 0.42 & (14) & 0.28 & (20) & 0.27 & (21) \\
\hline Journal of Money, Credit, and Banking & 0.40 & (15) & 0.39 & (13) & 0.32 & (17) \\
\hline National Tax Journal & 0.40 & (16) & 0.16 & (33) & 0.28 & (20) \\
\hline Journal of Econometrics & 0.35 & (17) & 0.29 & (18) & 0.24 & (25) \\
\hline Journal of International Economics & 0.33 & (18) & 0.43 & (12) & 0.35 & (13) \\
\hline Economic Inquiry & 0.32 & (19) & 0.27 & (23) & 0.15 & (33) \\
\hline Journal of Business & 0.31 & (20) & 0.37 & (16) & 0.30 & (19) \\
\hline Industrial and Labor Relations Review & 0.30 & (21) & 0.23 & (28) & 0.31 & (18) \\
\hline Journal of Human Resources & 0.29 & (22) & 0.15 & (35) & 0.24 & (26) \\
\hline Journal of Urban Economics & 0.28 & (23) & 0.17 & $(31)$ & 0.13 & (36) \\
\hline Economica & 0.27 & (24) & 0.22 & (30) & 0.17 & (31) \\
\hline Journal of Financial and Quantitative Analysis & 0.26 & $(25)$ & 0.28 & $(21)$ & 0.35 & (14) \\
\hline Journal of Law and Economics & 0.21 & (26) & 0.26 & (24) & 0.16 & (32) \\
\hline Southern Economic Journal & 0.20 & (27) & 0.16 & (34) & 0.08 & (38) \\
\hline Economic Journal & 0.18 & (28) & 0.23 & (29) & 0.20 & (27) \\
\hline Journal of Legal Studies & 0.16 & (29) & 0.24 & (26) & 0.12 & (37) \\
\hline Journal of Economic Dynamics and Control & 0.14 & (30) & 0.15 & (36) & 0.15 & (34) \\
\hline Oxford Economic Papers & 0.13 & (31) & 0.12 & (40) & 0.15 & (35) \\
\hline Journal of Economic History & 0.13 & (32) & 0.13 & (37) & 0.07 & (39) \\
\hline Journal of Regional Science & 0.13 & (33) & 0.12 & (39) & 0.07 & $(40)$ \\
\hline European Economic Review & 0.12 & (34) & 0.17 & (32) & 0.26 & (24) \\
\hline Journal of Development Economics & 0.10 & (35) & 0.13 & (38) & 0.19 & (28) \\
\hline Economic Development and Cultural Change & 0.09 & (36) & 0.05 & (41) & 0.06 & (41) \\
\hline Journal of Business and Economic Statistics & -- & & 0.51 & (10) & 0.39 & (10) \\
\hline Review of Financial Studies & -- & & 0.32 & (17) & 0.36 & (12) \\
\hline Journal of Labor Economics & -- & & 0.29 & (19) & 0.26 & (22) \\
\hline Journal of Law, Economics and Organization & -- & & 0.24 & (27) & 0.26 & (23) \\
\hline Journal of International Money and Finance & -- & & 0.26 & (25) & 0.17 & (30) \\
\hline
\end{tabular}




\section{Table 3, Summary Statistics \& Correlations for Individual Productivity Measures}

Panel A presents the mean, median, maximum and standard deviation for our 4 measures of productivity. Panels B and C present Spearman Rank Correlation and Pearson Correlation among the four productivity measures. Impact and raw productivities are measured as the count of $A E R$ equivalent pages written by each faculty in 41 economics and finance journals. Adjustment to AER equivalents normalizes by font, typesetting and average article length. Publication pages are divided by $1 / \mathrm{n}$ coauthors. Impact productivity multiplies each article by the decade impact factor of the journal published given in Table 2. Article counts is the simple sum of articles published by year. Citations sums the count of cites received as of May 2005 for each article written by the faculty in that year.

Panel A: Summary Statistics

\begin{tabular}{lccccc}
\hline Productivity & Decade & Mean & Median & Max & St. Dev. \\
\hline Raw & $1970 \mathrm{~s}$ & 5.8 & 0 & 105.4 & 10.1 \\
& $1980 \mathrm{~s}$ & 6.7 & 0 & 112.7 & 11.5 \\
& $1990 \mathrm{~s}$ & 6.2 & 0 & 138.4 & 11.9 \\
& Overall & 6.3 & 0 & 138.4 & 1.5 \\
\hline Impact & $1970 \mathrm{~s}$ & 3.2 & 0 & 74.6 & 6.2 \\
& $1980 \mathrm{~s}$ & 3.4 & 0 & 70.1 & 6.5 \\
& $1990 \mathrm{~s}$ & 3.0 & 0 & 103.9 & 6.3 \\
\hline Article Counts & Overall & 3.1 & 0 & 103.9 & 6.3 \\
& $1970 \mathrm{~s}$ & 0.75 & 0 & 9 & 1.10 \\
& $1980 \mathrm{~s}$ & 0.70 & 0 & 13 & 1.05 \\
& $1990 \mathrm{~s}$ & 0.53 & 0 & 8 & 0.89 \\
\hline Citations & Overall & 0.62 & 0 & 13 & 0.99 \\
& $1970 \mathrm{~s}$ & 27.5 & 0 & 3467 & 120.1 \\
& $1980 \mathrm{~s}$ & 25.7 & 0 & 3396 & 92.8 \\
& $1990 \mathrm{~s}$ & 7.8 & 0 & 693 & 28.8 \\
\hline
\end{tabular}

Panel B: Spearman Rank Correlation

\begin{tabular}{c|cccc}
\hline & Impact & Raw & Article Count & Citations \\
\hline Impact & 1 & & & \\
Raw & 0.981 & 1 & & \\
Article Counts & 0.969 & 0.974 & 1 & 1 \\
Citations & 0.862 & 0.851 & 0.860 & 1 \\
\hline
\end{tabular}

Panel C: Pearson Correlation

\begin{tabular}{c|cccc}
\hline & Impact & Raw & Article Count & Citations \\
\hline Impact & 1 & & & \\
Raw & 0.871 & 1 & & \\
Article Counts & 0.783 & 0.850 & 1 & 1 \\
Citations & 0.421 & 0.357 & 0.401 & 1 \\
\hline
\end{tabular}




\section{Table 4 - Average Individual Productivities for Faculty by University and Decade}

Individual raw productivity is measured as the count of $A E R$ equivalent pages written by each faculty in 41 economics and finance journals. Adjustment to $A E R$ equivalents requires normalizing by font, typesetting and average article length such to equilibrate words across journals. Publication pages are divided by $1 / \mathrm{n}$ coauthors. Impact productivity multiplies each article by the decade impact factor of the journal published given in Table 2. Article count is the simple sum of articles published by year. The 1990s decade includes 2000 and 2001. The Others category reports the productivity of individuals who have ever been or will be at top 25 universities but who are at non-top 25 universities for that year observation. The method for determining the top 25 universities is discussed in the data section and Table 1. All averages are averages over faculty in the set of universities, not raw averages across universities.

\begin{tabular}{|c|c|c|c|c|c|c|c|c|c|}
\hline & \multicolumn{3}{|c|}{ Impact Productivity } & \multicolumn{3}{|c|}{ Raw Productivity } & \multicolumn{3}{|c|}{ Article Counts } \\
\hline & $1970 \mathrm{~s}$ & $1980 s$ & $1990 s$ & $1970 s$ & $1980 s$ & $1990 s$ & $1970 s$ & $1980 \mathrm{~s}$ & $1990 s$ \\
\hline MIT & 5.89 & 6.24 & 6.40 & 9.90 & 11.13 & 11.56 & 1.26 & 1.13 & 0.97 \\
\hline Chicago & 5.54 & 5.69 & 5.69 & 8.85 & 9.62 & 9.66 & 0.99 & 0.94 & 0.80 \\
\hline OSU & 5.09 & 3.39 & 4.01 & 8.87 & 6.98 & 7.99 & 1.14 & 0.83 & 0.75 \\
\hline Harvard & 4.89 & 4.35 & 4.97 & 8.44 & 8.20 & 8.72 & 0.94 & 0.92 & 0.80 \\
\hline Carnegie & 4.49 & 4.60 & 2.47 & 7.28 & 8.51 & 5.15 & 0.93 & 0.90 & 0.49 \\
\hline Rochester & 4.46 & 4.47 & 3.21 & 7.26 & 7.80 & 6.20 & 0.77 & 0.78 & 0.52 \\
\hline UCLA & 4.21 & 4.78 & 3.90 & 7.41 & 8.98 & 8.12 & 0.96 & 0.93 & 0.69 \\
\hline Yale & 4.13 & 3.69 & 2.97 & 7.29 & 7.51 & 6.85 & 0.83 & 0.79 & 0.56 \\
\hline Princeton & 3.81 & 6.95 & 5.54 & 6.88 & 12.02 & 9.93 & 0.92 & 1.27 & 0.84 \\
\hline Penn & 3.64 & 3.68 & 4.01 & 6.61 & 6.91 & 7.88 & 0.82 & 0.77 & 0.74 \\
\hline Stanford & 3.59 & 4.39 & 4.03 & 6.36 & 7.90 & 7.39 & 0.86 & 0.83 & 0.61 \\
\hline Columbia & 2.99 & 2.56 & 2.51 & 5.02 & 5.65 & 5.21 & 0.69 & 0.61 & 0.46 \\
\hline UBC & 2.77 & 2.46 & 2.44 & 5.48 & 5.28 & 5.79 & 0.74 & 0.60 & 0.50 \\
\hline Northwestern & 2.56 & 3.80 & 3.33 & 4.77 & 7.06 & 7.13 & 0.63 & 0.73 & 0.61 \\
\hline Berkeley & 2.56 & 2.63 & 2.72 & 4.34 & 5.25 & 5.95 & 0.52 & 0.65 & 0.53 \\
\hline NYU & 2.49 & 2.22 & 2.86 & 4.59 & 4.04 & 5.23 & 0.74 & 0.53 & 0.53 \\
\hline Purdue & 2.48 & 2.00 & 1.97 & 5.17 & 4.12 & 3.56 & 0.86 & 0.55 & 0.40 \\
\hline Michigan & 2.19 & 3.03 & 2.43 & 4.05 & 5.33 & 5.32 & 0.61 & 0.61 & 0.48 \\
\hline Washington & 2.08 & 2.33 & 1.69 & 4.22 & 4.75 & 4.61 & 0.48 & 0.51 & 0.41 \\
\hline Wisconsin & 1.96 & 1.97 & 2.58 & 4.14 & 4.52 & 6.06 & 0.59 & 0.54 & 0.53 \\
\hline USC & 1.96 & 1.93 & 2.53 & 3.70 & 4.69 & 5.64 & 0.52 & 0.48 & 0.50 \\
\hline Cornell & 1.87 & 2.48 & 2.10 & 4.15 & 5.82 & 5.22 & 0.59 & 0.72 & 0.47 \\
\hline Indiana & 1.61 & 1.56 & 1.40 & 3.82 & 3.25 & 3.69 & 0.45 & 0.38 & 0.34 \\
\hline Duke & 0.97 & 2.72 & 2.47 & 2.35 & 5.81 & 5.06 & 0.41 & 0.62 & 0.43 \\
\hline Texas & 0.39 & 0.97 & 1.97 & 0.87 & 2.21 & 4.44 & 0.12 & 0.26 & 0.36 \\
\hline Top 25 & 3.34 & 3.63 & 3.43 & 5.96 & 6.87 & 6.80 & 0.76 & 0.75 & 0.60 \\
\hline Others & 2.79 & 2.33 & 2.03 & 5.25 & 5.16 & 4.83 & 0.72 & 0.61 & 0.45 \\
\hline All Schools & 3.20 & 3.23 & 2.91 & 5.78 & 6.34 & 6.07 & 0.75 & 0.70 & 0.54 \\
\hline Top 25-Others & 0.55 & 1.30 & 1.40 & 0.70 & 1.71 & 1.97 & 0.04 & 0.14 & 0.15 \\
\hline
\end{tabular}




\section{Table 5, Panel A: Determinants of Faculty Productivity}

Observations are at the individual-year level. Impact and raw productivities are measured as the count of $A E R$ equivalent pages written by each faculty in 41 economics and finance journals. Adjustment to $A E R$ equivalents normalizes by font, typesetting and average article length. Publication pages are divided by $1 / \mathrm{n}$ coauthors. Impact productivity multiplies each article by the decade impact factor of the journal published given in Table 2 . Article count is the simple sum of articles published by year. The 1990s decade includes 2000 and 2001. Career years is the years since Ph.D. Associate and Full Professor, Chaired, and Visiting are indicator variables for the position of the faculty. Editor impact is the sum of the impact factors for the journals for which the faculty serves as an editor or co-editor. All columns include individual fixed effects. Columns 2, 4 and 6 add university-field fixed effects. Article counts are estimated with Poisson Regression. T-statistics are in parentheses. $* * *, * *$, and $*$ denote significance at the $1 \%, 5 \%$ and $10 \%$ levels respectively.

\begin{tabular}{|c|c|c|c|c|c|c|}
\hline Dependent Variable: & \multicolumn{2}{|c|}{ Impact Productivity } & \multicolumn{2}{|c|}{ Raw Productivity } & \multicolumn{2}{|c|}{ Article Count } \\
\hline & 1 & 2 & 3 & 4 & 5 & 6 \\
\hline Career Years & $\begin{array}{l}-0.010 \\
(0.28)\end{array}$ & $\begin{array}{l}0.007 \\
(0.21)\end{array}$ & $\begin{array}{l}0.099 \\
(1.16)\end{array}$ & $\begin{array}{l}0.123 \\
(1.45)\end{array}$ & $\begin{array}{c}0.045 * * * \\
(6.01)\end{array}$ & $\begin{array}{c}0.046 * * * \\
(6.04)\end{array}$ \\
\hline Career Years ${ }^{\wedge} 2$ & $\begin{array}{c}-0.006 * * * \\
(2.88)\end{array}$ & $\begin{array}{c}-0.007 * * * \\
(3.69)\end{array}$ & $\begin{array}{c}-0.015 * * * \\
(3.35)\end{array}$ & $\begin{array}{c}-0.018 * * * \\
(3.83)\end{array}$ & $\begin{array}{c}-0.005 * * * \\
(11.04)\end{array}$ & $\begin{array}{c}-0.005 * * * \\
(11.10)\end{array}$ \\
\hline Career Years` 3 (in $1,000 s$ ) & $\begin{array}{c}0.101 * * * \\
(2.99)\end{array}$ & $\begin{array}{c}0.138 * * * \\
(3.84)\end{array}$ & $\begin{array}{c}0.242 * * * \\
(3.19)\end{array}$ & $\begin{array}{c}0.297 * * * \\
(3.69)\end{array}$ & $\begin{array}{c}0.070 * * * \\
(9.00)\end{array}$ & $\begin{array}{c}0.072 * * * \\
(9.16)\end{array}$ \\
\hline Associate Professor & $\begin{array}{c}-0.487 * * * \\
(3.09)\end{array}$ & $\begin{array}{c}-0.455 * * * \\
(2.78)\end{array}$ & $\begin{array}{c}-1.131 * * * \\
(3.43)\end{array}$ & $\begin{array}{c}-1.022 * * * \\
(3.07)\end{array}$ & $\begin{array}{c}-0.138 * * * \\
(4.91)\end{array}$ & $\begin{array}{c}-0.128 * * * \\
(4.45)\end{array}$ \\
\hline Full Professor & $\begin{array}{c}-0.895 * * * \\
(4.36)\end{array}$ & $\begin{array}{c}-0.876 * * * \\
(3.78)\end{array}$ & $\begin{array}{c}-1.946 * * * \\
(5.29)\end{array}$ & $\begin{array}{c}-1.841 * * * \\
(4.81)\end{array}$ & $\begin{array}{c}-0.237 * * * \\
(6.42)\end{array}$ & $\begin{array}{c}-0.224 * * * \\
(5.93)\end{array}$ \\
\hline Chaired Full Professor & $\begin{array}{c}-1.260 * * * * \\
(5.55)\end{array}$ & $\begin{array}{c}-1.055 * * * \\
(4.50)\end{array}$ & $\begin{array}{c}-2.515 * * * \\
(6.37)\end{array}$ & $\begin{array}{c}-2.184 * * * * \\
(5.37)\end{array}$ & $\begin{array}{c}-0.190 * * * \\
(4.23)\end{array}$ & $\begin{array}{c}-0.172 * * * \\
(3.72)\end{array}$ \\
\hline Editor Impact & $\begin{array}{l}-0.038 \\
(0.04)\end{array}$ & $\begin{array}{l}-0.039 \\
(0.04)\end{array}$ & $\begin{array}{l}-0.142 \\
(0.11)\end{array}$ & $\begin{array}{l}-0.162 \\
(0.13)\end{array}$ & $\begin{array}{l}0.045 \\
(0.78)\end{array}$ & $\begin{array}{l}0.029 \\
(0.49)\end{array}$ \\
\hline Visiting & $\begin{array}{l}0.028 \\
(0.33)\end{array}$ & $\begin{array}{l}0.034 \\
(0.42)\end{array}$ & $\begin{array}{l}0.161 \\
(0.91)\end{array}$ & $\begin{array}{l}0.163 \\
(0.96)\end{array}$ & $\begin{array}{l}0.051 * \\
(1.79)\end{array}$ & $\begin{array}{c}0.037 \\
(1.26)\end{array}$ \\
\hline Decade 1980s & $\begin{array}{l}0.180 \\
(1.60)\end{array}$ & $\begin{array}{c}0.481 * * \\
(2.42)\end{array}$ & $\begin{array}{c}0.841 * * * \\
(3.98)\end{array}$ & $\begin{array}{c}1.528 * * * \\
(4.76)\end{array}$ & $\begin{array}{c}0.042 \\
(1.36)\end{array}$ & $\begin{array}{c}0.108 * * \\
(2.28)\end{array}$ \\
\hline Decade $1990 \mathrm{~s}$ & $\begin{array}{l}0.237 \\
(1.44)\end{array}$ & $\begin{array}{c}1.116 * * * \\
(2.79)\end{array}$ & $\begin{array}{c}1.282 * * * \\
(3.49)\end{array}$ & $\begin{array}{c}2.831 * * * \\
(4.08)\end{array}$ & $\begin{array}{l}0.055 \\
(1.11)\end{array}$ & $\begin{array}{c}0.200 * * * \\
(3.24)\end{array}$ \\
\hline Finance*Decade 1970 s & $\begin{array}{c}-1.278 * * \\
(2.47)\end{array}$ & $\begin{array}{l}-0.756 \\
(0.90)\end{array}$ & $\begin{array}{l}-0.470 \\
(0.52)\end{array}$ & $\begin{array}{l}0.835 \\
(0.65)\end{array}$ & $\begin{array}{l}0.319 \\
(1.60)\end{array}$ & $\begin{array}{l}0.333 \\
(1.47)\end{array}$ \\
\hline Finance*Decade1980s & $\begin{array}{c}-1.126 * * \\
(2.29)\end{array}$ & $\begin{array}{l}-0.387 \\
(0.49)\end{array}$ & $\begin{array}{l}-0.939 \\
(1.06)\end{array}$ & $\begin{array}{l}0.470 \\
(0.39)\end{array}$ & $\begin{array}{l}0.032 \\
(0.17)\end{array}$ & $\begin{array}{l}0.027 \\
(0.13)\end{array}$ \\
\hline Finance* Decade1990s & $\begin{array}{c}-0.975 * \\
(1.78)\end{array}$ & $\begin{array}{l}-0.434 \\
(0.55)\end{array}$ & $\begin{array}{l}-1.190 \\
(1.24)\end{array}$ & $\begin{array}{l}-0.023 \\
(0.02)\end{array}$ & $\begin{array}{l}-0.170 \\
(0.88)\end{array}$ & $\begin{array}{l}-0.271 \\
(1.27)\end{array}$ \\
\hline Constant & $\begin{array}{c}4.817 * * * \\
(13.99)\end{array}$ & $\begin{array}{c}4.017 * * * \\
(12.33)\end{array}$ & $\begin{array}{c}7.983 * * * \\
(13.54)\end{array}$ & $\begin{array}{c}6.287 * * * \\
(13.59)\end{array}$ & & \\
\hline Observations & 35,917 & 35,917 & 35,917 & 35,917 & 35,917 & 35,917 \\
\hline $\begin{array}{l}\text { F-Test (p-value) for } \\
\text { inclusion of Univ.F.E. }\end{array}$ & & $\begin{array}{c}35.28 \\
(0.000) \\
\end{array}$ & & $\begin{array}{r}18.55 \\
(0.000) \\
\end{array}$ & & $\begin{array}{l}228.58 \\
(0.000)\end{array}$ \\
\hline Individual Fixed Effects & Yes & Yes & Yes & Yes & Yes & Yes \\
\hline University Fixed Effects & No & Yes & No & Yes & No & Yes \\
\hline
\end{tabular}


Table 5, Panel B: University Fixed Effects across Decades and Field

University fixed effects estimates for the impact productivity estimation from Table 5, panel A, column 2.

\begin{tabular}{|c|c|c|c|c|c|c|}
\hline & \multicolumn{6}{|c|}{ Dependent Variable: Impact Productivity } \\
\hline & \multicolumn{3}{|c|}{ Economics Departments } & \multicolumn{3}{|c|}{ Finance Departments } \\
\hline & 1970s & $1980 \mathrm{~s}$ & 1990s & 1970s & 1980s & $1990 \mathrm{~s}$ \\
\hline Carnegie Mellon & $\begin{array}{c}-1.190 * * * \\
(4.89)\end{array}$ & $\begin{array}{l}0.432 * \\
(1.90)\end{array}$ & $\begin{array}{l}-0.109 \\
(0.56)\end{array}$ & $\begin{array}{c}1.717 * * * \\
(4.25)\end{array}$ & $\begin{array}{l}0.550 \\
(1.06)\end{array}$ & $\begin{array}{c}-1.062^{*} \\
(1.90)\end{array}$ \\
\hline Columbia & $\begin{array}{c}1.077 * * * \\
(3.96)\end{array}$ & $\begin{array}{l}-0.044 \\
(0.13)\end{array}$ & $\begin{array}{c}-0.847 * \\
(1.94)\end{array}$ & $\begin{array}{c}1.174 * * * \\
(8.43)\end{array}$ & $\begin{array}{l}-0.227 \\
(1.06)\end{array}$ & $\begin{array}{c}-0.347 * * \\
(2.03)\end{array}$ \\
\hline Cornell & $\begin{array}{c}-0.499 * * \\
(2.34)\end{array}$ & $\begin{array}{l}-0.332 \\
(0.90)\end{array}$ & $\begin{array}{l}-0.255 \\
(0.68)\end{array}$ & $\begin{array}{r}-0.045 \\
(0.11)\end{array}$ & $\begin{array}{c}-0.937 * * * \\
(4.44)\end{array}$ & $\begin{array}{c}-0.551 \\
(1.06)\end{array}$ \\
\hline Duke & $\begin{array}{c}-0.401 * \\
(1.84)\end{array}$ & $\begin{array}{l}0.367 \\
(1.64)\end{array}$ & $\begin{array}{c}-0.619 * * * \\
(2.86)\end{array}$ & $\begin{array}{c}-0.535 * * * \\
(2.62)\end{array}$ & $\begin{array}{c}0.233 * \\
(1.95)\end{array}$ & $\begin{array}{c}-0.656 * * * \\
(4.78)\end{array}$ \\
\hline Harvard & $\begin{array}{c}2.127 * * * \\
(11.33)\end{array}$ & $\begin{array}{l}0.250 \\
(1.00)\end{array}$ & $\begin{array}{c}-1.781 * * * \\
(5.53)\end{array}$ & $\begin{array}{c}-2.249 * * * \\
(3.90)\end{array}$ & $\begin{array}{c}-2.114 * * * \\
(3.33)\end{array}$ & $\begin{array}{c}-2.781 * * \\
(2.30)\end{array}$ \\
\hline Indiana & $\begin{array}{c}0.349 * * * \\
(2.65)\end{array}$ & $\begin{array}{c}0.819 * * * \\
(4.73)\end{array}$ & $\begin{array}{l}0.149 \\
(0.87)\end{array}$ & $\begin{array}{c}1.846 * * * \\
(29.39)\end{array}$ & $\begin{array}{c}-0.883 * * * \\
(3.39)\end{array}$ & $\begin{array}{c}0.246 * * \\
(2.36)\end{array}$ \\
\hline MIT & $\begin{array}{c}1.003 * * * \\
(5.28)\end{array}$ & $\begin{array}{c}0.560 * * * \\
(3.10)\end{array}$ & $\begin{array}{c}-1.208 * * * * \\
(3.30)\end{array}$ & $\begin{array}{l}1.533 * \\
(1.92)\end{array}$ & $\begin{array}{l}0.819 \\
(0.81)\end{array}$ & $\begin{array}{c}-0.128 \\
(0.20)\end{array}$ \\
\hline New York U & $\begin{array}{r}-0.307 \\
(0.95)\end{array}$ & $\begin{array}{c}-0.300 \\
(0.67)\end{array}$ & $\begin{array}{r}-0.279 \\
(0.59)\end{array}$ & $\begin{array}{c}1.457 * * * \\
(10.99)\end{array}$ & $\begin{array}{c}0.340 * * \\
(1.97)\end{array}$ & $\begin{array}{c}0.991 * * * \\
(7.95)\end{array}$ \\
\hline Northwestern & $\begin{array}{c}0.892 * * * \\
(5.59)\end{array}$ & $\begin{array}{c}1.377 * * * \\
(6.68)\end{array}$ & $\begin{array}{l}0.351 \\
(1.01)\end{array}$ & $\begin{array}{c}0.427 * \\
(1.75)\end{array}$ & $\begin{array}{c}0.743 * * * \\
(3.47)\end{array}$ & $\begin{array}{r}-0.253 \\
(0.75)\end{array}$ \\
\hline Ohio State U & $\begin{array}{c}1.535 * * * \\
(7.48)\end{array}$ & $\begin{array}{c}-0.348 * \\
(1.68)\end{array}$ & $\begin{array}{c}-0.892 * * * \\
(3.22)\end{array}$ & $\begin{array}{c}2.365 * * * \\
(11.58)\end{array}$ & $\begin{array}{r}-0.181 \\
(0.69)\end{array}$ & $\begin{array}{l}-0.270 \\
(0.47)\end{array}$ \\
\hline Princeton & $\begin{array}{c}1.220 * * * \\
(4.16)\end{array}$ & $\begin{array}{c}1.530 * * * \\
(4.81)\end{array}$ & $\begin{array}{c}-0.439 \\
(0.96)\end{array}$ & & & \\
\hline Purdue & $\begin{array}{c}-0.276 \\
(0.50)\end{array}$ & $\begin{array}{c}-0.911 * * * \\
(3.49)\end{array}$ & $\begin{array}{c}-0.821 * * * \\
(2.59)\end{array}$ & $\begin{array}{c}0.952 * * \\
(2.24)\end{array}$ & $\begin{array}{c}1.396 * * \\
(2.18)\end{array}$ & $\begin{array}{c}0.056 \\
(0.11)\end{array}$ \\
\hline Stanford & $\begin{array}{c}1.313 * * * \\
(7.62)\end{array}$ & $\begin{array}{l}0.332 \\
(1.25)\end{array}$ & $\begin{array}{c}-1.074 * * * \\
(3.29)\end{array}$ & $\begin{array}{c}1.193 * * * \\
(3.83)\end{array}$ & $\begin{array}{c}2.719 * * * \\
(6.82)\end{array}$ & $\begin{array}{c}1.141 * * \\
(2.17)\end{array}$ \\
\hline U British Columbia & $\begin{array}{c}0.564 * * * \\
(2.61)\end{array}$ & $\begin{array}{l}0.196 \\
(0.80)\end{array}$ & $\begin{array}{c}0.415 * \\
(1.80)\end{array}$ & $\begin{array}{c}3.285 * * * \\
(3.01)\end{array}$ & $\begin{array}{l}0.320 \\
(1.29)\end{array}$ & $\begin{array}{l}0.497 \\
(1.49)\end{array}$ \\
\hline UC Berkeley & $\begin{array}{c}-0.475 * * \\
(2.32)\end{array}$ & $\begin{array}{l}-0.147 \\
(0.56)\end{array}$ & $\begin{array}{c}-0.932 * * * \\
(3.29)\end{array}$ & $\begin{array}{l}0.214 \\
(0.64)\end{array}$ & $\begin{array}{c}-0.866^{* *} \\
(2.26)\end{array}$ & $\begin{array}{l}-0.319 \\
(0.94)\end{array}$ \\
\hline UC Los Angeles & $\begin{array}{c}1.425 * * * \\
(3.61)\end{array}$ & $\begin{array}{l}0.635 \\
(1.56)\end{array}$ & $\begin{array}{r}-0.345 \\
(1.11)\end{array}$ & $\begin{array}{c}2.025 * * * \\
(11.25)\end{array}$ & $\begin{array}{c}0.987 * * \\
(2.26)\end{array}$ & $\begin{array}{l}\text { 0.508* } \\
(1.72)\end{array}$ \\
\hline U of Chicago & $\begin{array}{c}1.796 * * * \\
(8.66)\end{array}$ & $\begin{array}{c}0.889 * * * \\
(2.91)\end{array}$ & $\begin{array}{l}-0.463 \\
(1.56)\end{array}$ & $\begin{array}{c}2.466 * * * \\
(12.08)\end{array}$ & $\begin{array}{c}1.465 * * * \\
(6.12)\end{array}$ & $\begin{array}{c}-0.460 \\
(1.19)\end{array}$ \\
\hline U of Michigan & $\begin{array}{c}0.892 * * * \\
(6.10)\end{array}$ & $\begin{array}{c}1.149 * * * \\
(7.56)\end{array}$ & $\begin{array}{l}0.357^{*} \\
(1.74)\end{array}$ & $\begin{array}{c}1.259 * * * \\
(4.19)\end{array}$ & $\begin{array}{c}1.001 * * * \\
(3.11)\end{array}$ & $\begin{array}{c}-0.621 * * \\
(2.17)\end{array}$ \\
\hline U of Pennsylvania & $\begin{array}{l}1.217 * * * \\
(5.11)\end{array}$ & $\begin{array}{c}0.868 * * * \\
(5.18)\end{array}$ & $\begin{array}{l}-0.167 \\
(0.89)\end{array}$ & $\begin{array}{c}0.591 * * * \\
(3.47)\end{array}$ & $\begin{array}{c}-0.539 * \\
(1.76)\end{array}$ & $\begin{array}{c}-0.210 \\
(0.66)\end{array}$ \\
\hline U of Rochester & $\begin{array}{c}1.420 * * * \\
(5.89)\end{array}$ & $\begin{array}{c}1.552 * * * \\
(5.74)\end{array}$ & $\begin{array}{l}0.166 \\
(0.60)\end{array}$ & $\begin{array}{r}-0.163 \\
(0.29)\end{array}$ & $\begin{array}{c}-1.045 * * * \\
(3.38)\end{array}$ & $\begin{array}{c}-0.558 * \\
(1.65)\end{array}$ \\
\hline U of Southern Calif. & $\begin{array}{c}0.293 * * * \\
(2.69)\end{array}$ & $\begin{array}{c}-0.437 * * * \\
(4.95)\end{array}$ & $\begin{array}{l}0.031 \\
(0.15)\end{array}$ & $\begin{array}{r}-0.101 \\
(0.19)\end{array}$ & $\begin{array}{c}1.338 * * * \\
(3.97)\end{array}$ & $\begin{array}{l}-0.485 \\
(1.58)\end{array}$ \\
\hline $\mathrm{U}$ of Texas & $\begin{array}{r}-0.059 \\
(0.17)\end{array}$ & $\begin{array}{c}-0.138 \\
(0.47)\end{array}$ & $\begin{array}{c}-0.171 \\
(0.34)\end{array}$ & $\begin{array}{c}-0.631 * * \\
(2.35)\end{array}$ & $\begin{array}{r}-0.193 \\
(0.59)\end{array}$ & $\begin{array}{l}-0.180 \\
(0.32)\end{array}$ \\
\hline $\mathrm{U}$ of Washington & $\begin{array}{c}-0.600 * * * \\
(2.95)\end{array}$ & $\begin{array}{c}-0.501 * \\
(1.85)\end{array}$ & $\begin{array}{c}-1.462 * * * \\
(4.15)\end{array}$ & $\begin{array}{l}1.094 \\
(1.48)\end{array}$ & $\begin{array}{l}-0.036 \\
(0.04)\end{array}$ & $\begin{array}{l}-1.041 \\
(1.09)\end{array}$ \\
\hline $\mathrm{U}$ of Wisconsin & $\begin{array}{c}0.316 * * \\
(2.51)\end{array}$ & $\begin{array}{c}-0.227 \\
(1.09)\end{array}$ & $\begin{array}{l}-0.676 \\
(1.49)\end{array}$ & $\begin{array}{c}0.687 * * * \\
(3.32)\end{array}$ & $\begin{array}{l}0.060 \\
(0.30)\end{array}$ & $\begin{array}{l}0.497 \\
(1.63)\end{array}$ \\
\hline Yale & $\begin{array}{c}1.029 * * * \\
(3.35)\end{array}$ & $\begin{array}{l}-0.028 \\
(0.07)\end{array}$ & $\begin{array}{l}-0.100 \\
(0.26)\end{array}$ & $\begin{array}{c}1.882 * * * \\
(2.72)\end{array}$ & $\begin{array}{c}1.036 * * * \\
(3.56)\end{array}$ & $\begin{array}{c}-1.660 * * * \\
(4.19)\end{array}$ \\
\hline Significant $(+)$ Count & 17 & 9 & 2 & 16 & 10 & 4 \\
\hline Significant (-) Count & 5 & 4 & 9 & 3 & 6 & 7 \\
\hline
\end{tabular}




\section{Table 6: Change in Individual Adjusted Impact Productivity following Moves}

The transition matrix below presents the change in Individual Adjusted Impact Productivity around a move, where Individual Adjusted Impact Productivity is the residual of regressing impact productivity on rank, career years, career years squared, career years cubed, visiting, and editor impact. To construct the statistics below, we calculate the average of the two years of adjusted productivity following a move and subtract from it the average of the two years of adjusted productivity prior to the move. We exclude the move year in both pre- and post-measures. A move up is defined to be a move into a top 5 university by anyone or a move into a top 25 university by those from other school. The top 5 are chosen as those with the highest decade average individual productivity in the field. A lateral move is moving within the top 5, within the top 6-25 universities or within others. A move down is a move from top 5 to top 6-26 or from top 25 to others. The observation counts for moves in each category are given below the change in productivity. Asterisks *,**, and $* * *$ denote significance at a $10 \%, 5 \%$ and $1 \%$ level.

\begin{tabular}{|c|c|c|c|}
\hline \multicolumn{4}{|c|}{ Assistant and Associate Professors } \\
\hline & $1970 s$ & $1980 s$ & $1990 s$ \\
\hline Move Down & $\begin{array}{c}0.558 \\
54\end{array}$ & $\begin{array}{c}-\mathbf{- 0 . 8 0 6 *} \\
119\end{array}$ & $\begin{array}{c}0.337 \\
145\end{array}$ \\
\hline Lateral & $\begin{array}{c}-0.795 \\
63\end{array}$ & $\begin{array}{c}-0.484 \\
131\end{array}$ & $\begin{array}{c}0.240 \\
124\end{array}$ \\
\hline Up & $\begin{array}{c}2.013^{* * *} \\
31\end{array}$ & $\begin{array}{c}0.454 \\
75\end{array}$ & $\begin{array}{c}-0.254 \\
60\end{array}$ \\
\hline All Moves & $\begin{array}{c}0.287 \\
148\end{array}$ & $\begin{array}{c}-0.385 \\
325\end{array}$ & $\begin{array}{c}0.193 \\
329\end{array}$ \\
\hline \multicolumn{4}{|c|}{ Full Professors } \\
\hline & $1970 s$ & $1980 s$ & $1990 s$ \\
\hline Move Down & $\begin{array}{c}-1.008 \\
37\end{array}$ & $\begin{array}{c}-0.151 \\
104\end{array}$ & $\begin{array}{c}-0.692 \\
123\end{array}$ \\
\hline Lateral & $\begin{array}{c}-1.938 * * \\
40\end{array}$ & $\begin{array}{c}-0.493 \\
111\end{array}$ & $\begin{array}{c}-0.172 \\
164\end{array}$ \\
\hline Up & $\begin{array}{c}-0.067 \\
28\end{array}$ & $\begin{array}{c}1.326 \\
66\end{array}$ & $\begin{array}{c}-1.119 * \\
95\end{array}$ \\
\hline All Moves & $\begin{array}{c}-1.112 * \\
105\end{array}$ & $\begin{array}{c}0.061 \\
281\end{array}$ & $\begin{array}{c}-0.575 * * \\
382\end{array}$ \\
\hline
\end{tabular}




\section{Table 7: Determinants of Faculty Productivity - Selection Model}

Panel A presents the logit estimation of the probability of moving as in equation (3) (i). The dependent variable is an indicator for a move. We estimate a fourth order polynomial of the individual's age, calculated as the current year minus the undergraduate year plus 22. A likelihood ratio test (LRT) is given for testing joint relevance of the variables in estimating the probability of a move.

Panel B presents the conditional logit selection estimation of the probability of being at a given location as in equation (3) (ii). The dependent variable is an indicator variable for the faculty being at the potential school for each year. Flight Time is the difference in flight times (expressed in 100s of minutes) to the origin home city, defined as the city of the undergraduate institution, from the prior year location and potential location. Prior Location is an indicator for the potential location being a different university than the university from the prior year. Not Prior Location $=1-$ Prior Location, for convenience of interpretation. PhDSchool Location is an indicator for whether the potential school is the location of the individuals' Ph.D. degree. It is allowed to equal 1 only for individuals whose prior year school is a top 5 school and who have graduated from their Ph.D. program more than 2 years prior. Productivity distance is the difference between the individual's two-prior-year average productivity and the potential locations' average two prior year productivity. For assistant and associate professors, we take the absolute value of this number, as described in the text. Associate, Full, and Chaired are rank indicator variables. Robust standard errors are clustered at the school level. A Wald test statistic is provided for testing joint relevance of the variables in the estimation.

Panels C and D present the estimation results from the second stage of the selection model. The only difference in these estimations from those of Table 5 is that the contrast matrix setting up the university fixed effects estimation has been replaced by the predicted probability of each individual being at each location, estimated in the conditional logit in step 1. Impact productivity is the dependent variable and is measured as the count of $A E R$ equivalent pages written by each faculty in 41 economics and finance journals with each article multiplied by the decade impact factor of the journal published given in Table 2. Adjustment to AER equivalents normalizes by font, typesetting and average article length. Publication pages are divided by $1 / \mathrm{n}$ coauthors. The 1990 s decade includes 2000 and 2001. Career years is the years since Ph.D. The model is fit with individual fixed effects. Standard errors are adjusted to account for the first stage variance by bootstrapping the first stage, taking the variance of the predicted probabilities and adding the variance to the regression variance in the second stage following Petrin and Train (2001). In all panels, T-statistics are in parentheses. $* * *, * *$, and $*$ denote significance at the $1 \%, 5 \%$ and $10 \%$ levels respectively.

Panel A: First Stage - Selection to Move

\begin{tabular}{lc}
\hline & Dependent variable: Indicator for Moves \\
\hline Age & $\mathbf{7 . 2 9} * * * *$ \\
& $\mathbf{( 7 . 8 9 )}$ \\
$\operatorname{Age}^{2}$ & $\mathbf{- 0 . 2 3} * * *$ \\
& $\mathbf{( 7 . 2 7 )}$ \\
$\operatorname{Age}^{3}(/ 1,000)$ & $\mathbf{3 . 2 3} * * *$ \\
& $\mathbf{( 6 . 6 3 )}$ \\
$\operatorname{Age}^{4}(/ 1,000,000)$ & $\mathbf{- 1 6 . 3 7 * * *}$ \\
& $\mathbf{( 6 . 0 4 )}$ \\
Constant & $\mathbf{- 8 4 . 8 3 * * *}$ \\
& $\mathbf{( 8 . 7 2 )}$ \\
Observations & 35,993 \\
Pseudo R-Square & 0.037 \\
LRT Test Statistic for Relevance & 541.2 \\
\hline
\end{tabular}




\section{Panel B: First Stage - Selection among Potential Schools}

\begin{tabular}{lc}
\hline Dependent variable: Indicator for each faculty being at each of 26 locations \\
\hline Flight Time & $\mathbf{0 . 2 2 3} * *$ \\
& $(\mathbf{2 . 0 1 )}$ \\
Prior Location & $\mathbf{5 . 3 7 5 * * *}$ \\
& $\mathbf{( 2 7 . 5 8 )}$ \\
PhDSchool Location & $\mathbf{1 . 1 2 2 * * *}$ \\
& $\mathbf{( 5 . 2 3 )}$ \\
PhDSchool Location * Non-Prior Location & $\mathbf{1 . 6 1 4} * * *$ \\
& $\mathbf{( 9 . 8 9 )}$ \\
Productivity Distance & $\mathbf{- 0 . 0 6 5 * * *}$ \\
& $\mathbf{( 3 . 1 6 )}$ \\
Productivity Distance * Associate & -0.021 \\
& $(0.59)$ \\
Productivity Distance * Full & -0.016 \\
& $(0.23)$ \\
Productivity Distance * Chaired & $\mathbf{- 0 . 1 1 8 *}$ \\
Observations & $(\mathbf{1 . 7 1 )}$ \\
Pseudo R-Square & 816,624 \\
Wald Test Statistic for Relevance & 0.821 \\
Robust standard errors clustered at school level & 42,415 \\
\hline
\end{tabular}


Panel C: Determinants of Faculty Productivity - Selection Model

\begin{tabular}{|c|c|}
\hline \multicolumn{2}{|c|}{ Dependent variable: Impact Productivity } \\
\hline Career Years & $\begin{array}{c}-0.222^{* * * *} \\
(4.99)\end{array}$ \\
\hline Career Years`2 & $\begin{array}{l}\text { 0.004* } \\
(1.94)\end{array}$ \\
\hline Career Years`3 & $\begin{array}{l}-0.048 \\
(1.32)\end{array}$ \\
\hline Associate Professor & $\begin{array}{c}-0.425 * * * \\
(2.77)\end{array}$ \\
\hline Full Professor & $\begin{array}{c}-0.651 * * * \\
(3.18)\end{array}$ \\
\hline Chaired Full & $\begin{array}{c}-0.855 * * * \\
(3.55)\end{array}$ \\
\hline Editor Impact & $\begin{array}{r}-0.348 \\
(0.94)\end{array}$ \\
\hline Visiting & $\begin{array}{l}0.022 \\
(0.16)\end{array}$ \\
\hline Decade 1980s & $\begin{array}{c}0.704 * * * \\
(2.96)\end{array}$ \\
\hline Decade 1990s & $\begin{array}{c}1.100 * * * \\
(3.65)\end{array}$ \\
\hline Finance*Decade1970s & $\begin{array}{l}-0.427 \\
(0.35)\end{array}$ \\
\hline Finance*Decade1980s & $\begin{array}{l}0.060 \\
(0.05)\end{array}$ \\
\hline Finance*Decade1990s & $\begin{array}{l}0.204 \\
(0.19)\end{array}$ \\
\hline Constant & $\begin{array}{c}4.969 * * * \\
(12.60)\end{array}$ \\
\hline $\begin{array}{l}\text { Observations } \\
\text { Individual Fixed Effects }\end{array}$ & $\begin{array}{c}29,754 \\
\text { Yes }\end{array}$ \\
\hline
\end{tabular}


Panel D: University Fixed Effects across Decades and Field - Selection Model

\begin{tabular}{|c|c|c|c|c|c|c|}
\hline & \multicolumn{6}{|c|}{ Dependent Variable: Impact Productivity } \\
\hline & \multicolumn{3}{|c|}{ Economics Departments } & \multicolumn{3}{|c|}{ Finance Departments } \\
\hline & 1970s & $1980 s$ & $1990 \mathrm{~s}$ & $1970 \mathrm{~s}$ & 1980s & 1990s \\
\hline Carnegie Mellon & $\begin{array}{c}-34.81 * \\
(1.74)\end{array}$ & $\begin{array}{l}15.44 \\
(1.46)\end{array}$ & $\begin{array}{l}0.02 \\
0.00\end{array}$ & $\begin{array}{c}81.72 * * * \\
(2.64)\end{array}$ & $\begin{array}{l}-2.00 \\
(0.12)\end{array}$ & $\begin{array}{l}-20.78 \\
(1.18)\end{array}$ \\
\hline Columbia & $\begin{array}{l}49.82 * * * \\
(2.84)\end{array}$ & $\begin{array}{l}-5.59 \\
(0.63)\end{array}$ & $\begin{array}{c}5.28 \\
(0.55)\end{array}$ & $\begin{array}{l}36.54 \\
(1.57)\end{array}$ & $\begin{array}{c}5.50 \\
(0.56)\end{array}$ & $\begin{array}{l}-0.17 \\
(0.02)\end{array}$ \\
\hline Cornell & $\begin{array}{c}0.61 \\
(0.05)\end{array}$ & $\begin{array}{l}-3.88 \\
(0.44)\end{array}$ & $\begin{array}{c}6.30 \\
(0.52)\end{array}$ & $\begin{array}{l}-10.62 \\
(0.32)\end{array}$ & $\begin{array}{l}-32.49 \\
(1.20)\end{array}$ & $\begin{array}{l}-15.95 \\
(0.48)\end{array}$ \\
\hline Duke & $\begin{array}{l}-5.57 \\
(0.40)\end{array}$ & $\begin{array}{c}9.14 \\
(0.86)\end{array}$ & $\begin{array}{l}-5.29 \\
(0.32)\end{array}$ & $\begin{array}{l}21.82 \\
(0.56)\end{array}$ & $\begin{array}{l}27.62 \\
(1.39)\end{array}$ & $\begin{array}{l}23.29 \\
(1.27)\end{array}$ \\
\hline Harvard & $\begin{array}{c}81.69 * * * \\
(6.31)\end{array}$ & $\begin{array}{c}14.61 * * \\
(2.05)\end{array}$ & $\begin{array}{c}-18.66 * * \\
(2.34)\end{array}$ & $\begin{array}{l}-2.52 \\
(0.03)\end{array}$ & $\begin{array}{l}-21.89 \\
(1.18)\end{array}$ & $\begin{array}{l}-25.49 \\
(1.36)\end{array}$ \\
\hline Indiana & $\begin{array}{l}29.26 \\
(1.44)\end{array}$ & $\begin{array}{l}11.80 \\
(0.97)\end{array}$ & $\begin{array}{c}8.52 \\
(0.49)\end{array}$ & $\begin{array}{l}24.94 \\
(0.60)\end{array}$ & $\begin{array}{l}-11.25 \\
(0.65)\end{array}$ & $\begin{array}{c}3.69 \\
(0.17)\end{array}$ \\
\hline MIT & $\begin{array}{c}26.41 * * * \\
(2.60)\end{array}$ & $\begin{array}{c}32.51 * * * \\
(3.87)\end{array}$ & $\begin{array}{l}-1.51 \\
(0.19)\end{array}$ & $\begin{array}{l}19.83 \\
(0.82)\end{array}$ & $\begin{array}{l}24.42 \\
(1.62)\end{array}$ & $\begin{array}{l}-3.59 \\
(0.23)\end{array}$ \\
\hline NYU & $\begin{array}{r}-17.31 \\
(1.33)\end{array}$ & $\begin{array}{c}-23.15 * * \\
(2.43)\end{array}$ & $\begin{array}{c}-25.90 * * \\
(2.23)\end{array}$ & $\begin{array}{c}5.91 \\
(0.31)\end{array}$ & $\begin{array}{c}2.06 \\
(0.21)\end{array}$ & $\begin{array}{c}23.25 * \\
(1.91)\end{array}$ \\
\hline Northwestern & $\begin{array}{c}6.71 \\
(0.56)\end{array}$ & $\begin{array}{c}14.31 * \\
(1.79)\end{array}$ & $\begin{array}{l}17.39 \% \\
(1.88)\end{array}$ & $\begin{array}{l}12.07 \\
(0.59)\end{array}$ & $\begin{array}{c}7.73 \\
(0.72)\end{array}$ & $\begin{array}{c}-24.06 * * \\
(2.01)\end{array}$ \\
\hline Ohio State & $\begin{array}{c}50.32 * * \\
(2.18)\end{array}$ & $\begin{array}{l}-15.68 \\
(0.99)\end{array}$ & $\begin{array}{c}-47.57^{*} \\
(1.86)\end{array}$ & $\begin{array}{l}31.27 \\
(0.87)\end{array}$ & $\begin{array}{c}6.80 \\
(0.43)\end{array}$ & $\begin{array}{l}-7.19 \\
(0.28)\end{array}$ \\
\hline Princeton & $\begin{array}{c}21.80 * * \\
(1.96)\end{array}$ & $\begin{array}{c}\text { 30.98*** } \\
(3.83)\end{array}$ & $\begin{array}{c}-14.22 * \\
(1.74)\end{array}$ & $\begin{array}{l}-- \\
--\end{array}$ & $\begin{array}{l}-- \\
--\end{array}$ & $\begin{array}{l}-- \\
--\end{array}$ \\
\hline Purdue & $\begin{array}{l}39.68 \\
(1.26)\end{array}$ & $\begin{array}{c}-27.50 * \\
(1.72)\end{array}$ & $\begin{array}{l}-29.12 \\
(1.45)\end{array}$ & $\begin{array}{l}-9.49 \\
(0.33)\end{array}$ & $\begin{array}{l}-3.03 \\
(0.16)\end{array}$ & $\begin{array}{l}-23.52 \\
(1.03)\end{array}$ \\
\hline Stanford & $\begin{array}{l}16.75 \\
(1.45)\end{array}$ & $\begin{array}{l}10.78 \\
(1.39)\end{array}$ & $\begin{array}{l}-10.62 \\
(1.00)\end{array}$ & $\begin{array}{l}11.68 \\
(0.52)\end{array}$ & $\begin{array}{c}30.47 * * \\
(2.27)\end{array}$ & $\begin{array}{l}-2.08 \\
(0.12)\end{array}$ \\
\hline $\mathrm{UBC}$ & $\begin{array}{l}15.93 \\
(1.12)\end{array}$ & $\begin{array}{c}-19.89 * \\
(1.79)\end{array}$ & $\begin{array}{l}-4.83 \\
(0.36)\end{array}$ & $\begin{array}{l}43.48 \\
(1.03)\end{array}$ & $\begin{array}{l}-4.12 \\
(0.28)\end{array}$ & $\begin{array}{l}-16.88 \\
(1.01)\end{array}$ \\
\hline UC Berkeley & $\begin{array}{l}11.39 \\
(0.96)\end{array}$ & $\begin{array}{c}2.77 \\
(0.32)\end{array}$ & $\begin{array}{l}-13.31 \\
(1.36)\end{array}$ & $\begin{array}{l}-19.23 \\
(0.69)\end{array}$ & $\begin{array}{c}8.85 \\
(0.52)\end{array}$ & $\begin{array}{c}7.41 \\
(0.36)\end{array}$ \\
\hline UCLA & $\begin{array}{l}-14.06 \\
(0.78)\end{array}$ & $\begin{array}{c}9.52 \\
(0.71)\end{array}$ & $\begin{array}{c}6.48 \\
(0.50)\end{array}$ & $\begin{array}{l}40.20 \\
(1.25)\end{array}$ & $\begin{array}{l}18.95 \\
(1.26)\end{array}$ & $\begin{array}{l}12.01 \\
(0.66)\end{array}$ \\
\hline U of Chicago & $\begin{array}{c}1.98 \\
(0.18)\end{array}$ & $\begin{array}{c}4.72 \\
(0.59)\end{array}$ & $\begin{array}{c}-11.82 \\
(1.34)\end{array}$ & $\begin{array}{l}21.16 \\
(1.03)\end{array}$ & $\begin{array}{c}19.14^{* *} \\
(2.10)\end{array}$ & $\begin{array}{l}-15.59 \\
(1.37)\end{array}$ \\
\hline U of Michigan & $\begin{array}{c}4.96 \\
(0.48)\end{array}$ & $\begin{array}{c}27.73 * * * \\
(2.93)\end{array}$ & $\begin{array}{c}26.81 * * \\
(2.47)\end{array}$ & $\begin{array}{l}-1.46 \\
(0.04)\end{array}$ & $\begin{array}{c}20.68 * \\
(1.73)\end{array}$ & $\begin{array}{c}3.25 \\
(0.27)\end{array}$ \\
\hline U of Pennsylvania & $\begin{array}{c}25.36 * * \\
(2.17)\end{array}$ & $\begin{array}{c}25.36 * * * * \\
(3.07)\end{array}$ & $\begin{array}{c}1.90 \\
(0.21)\end{array}$ & $\begin{array}{l}13.29 \\
(0.89)\end{array}$ & $\begin{array}{l}-11.77 \\
(1.31)\end{array}$ & $\begin{array}{l}-1.02 \\
(0.10)\end{array}$ \\
\hline U of Rochester & $\begin{array}{l}21.84 \\
(1.27)\end{array}$ & $\begin{array}{c}29.65 * * \\
(2.42)\end{array}$ & $\begin{array}{l}-3.57 \\
(0.29)\end{array}$ & $\begin{array}{l}-29.69 \\
(1.30)\end{array}$ & $\begin{array}{l}-12.43 \\
(1.03)\end{array}$ & $\begin{array}{l}-5.16 \\
(0.34)\end{array}$ \\
\hline USC & $\begin{array}{l}-10.97 \\
(0.55)\end{array}$ & $\begin{array}{l}-21.11 \\
(1.38)\end{array}$ & $\begin{array}{l}-17.36 \\
(1.11)\end{array}$ & $\begin{array}{c}8.64 \\
(0.25)\end{array}$ & $\begin{array}{l}14.12 \\
(0.63)\end{array}$ & $\begin{array}{l}-15.06 \\
(0.80)\end{array}$ \\
\hline $\mathrm{U}$ of Texas & $\begin{array}{l}-19.79 \\
(0.76)\end{array}$ & $\begin{array}{l}-11.67 \\
(0.69)\end{array}$ & $\begin{array}{l}-16.52 \\
(1.03)\end{array}$ & $\begin{array}{l}-3.33 \\
(0.17)\end{array}$ & $\begin{array}{l}-3.34 \\
(0.25)\end{array}$ & $\begin{array}{c}6.60 \\
(0.31)\end{array}$ \\
\hline $\mathrm{U}$ of Washington & $\begin{array}{l}-9.13 \\
(0.57)\end{array}$ & $\begin{array}{l}-8.44 \\
(0.57)\end{array}$ & $\begin{array}{l}-22.44 \\
(1.25)\end{array}$ & $\begin{array}{c}5.58 \\
(0.27)\end{array}$ & $\begin{array}{c}6.46 \\
(0.42)\end{array}$ & $\begin{array}{l}-15.09 \\
(0.63)\end{array}$ \\
\hline U of Wisconsin & $\begin{array}{c}7.94 \\
(0.70)\end{array}$ & $\begin{array}{l}-6.58 \\
(0.77)\end{array}$ & $\begin{array}{l}-6.71 \\
(0.62)\end{array}$ & $\begin{array}{l}84.26 \\
(1.20)\end{array}$ & $\begin{array}{c}4.68 \\
(0.19)\end{array}$ & $\begin{array}{l}25.17 \\
(1.27)\end{array}$ \\
\hline Yale & $\begin{array}{c}2.92 \\
(0.29) \\
\end{array}$ & $\begin{array}{l}-4.66 \\
(0.58) \\
\end{array}$ & $\begin{array}{l}-12.01 \\
(1.32) \\
\end{array}$ & $\begin{array}{c}144.10 * * * \\
(3.07)\end{array}$ & $\begin{array}{c}38.30 * * \\
(2.44)\end{array}$ & $\begin{array}{l}-24.23 \\
(1.04) \\
\end{array}$ \\
\hline Significant $(+)$ Count & 6 & 7 & 2 & 2 & 4 & 1 \\
\hline Significant (-) Count & 1 & 2 & 4 & 0 & 0 & 1 \\
\hline
\end{tabular}




\section{Table 8: Determinants of Faculty Productivity \& Team Externality}

Only two differences distinguish the regression from column 2 of Table 5. First, included is the variable team, calculated as the prior two year average productivity of all colleagues in one' department who are productive for the years considered. Second, all columns include individual fixed effects and university random effects. As before, observations are at the individual-year level. Impact productivity is measured as the count of AER equivalent pages written by each faculty in 41 economics and finance journals, normalized by font, typesetting and average article length, divided by $1 / \mathrm{n}$ coauthors and multiplied by the decade impact factor of the journal. Career years is the years since Ph.D. Associate and Full Professor, Chaired, and Visiting are indicator variables for the position of the faculty. Editor impact is the sum of the impact factors for the journals for which the faculty serves as an editor or co-editor. Tstatistics are in parentheses. $* * *, * *$, and $*$ denote significance at the $1 \%, 5 \%$ and $10 \%$ levels respectively.

\begin{tabular}{|c|c|}
\hline \multicolumn{2}{|c|}{ Dependent Variable: Impact Productivity } \\
\hline Career Years & $\begin{array}{r}-0.005 \\
(0.13)\end{array}$ \\
\hline Career Years ${ }^{\wedge} 2$ & $\begin{array}{c}-0.006 * * * \\
(3.27)\end{array}$ \\
\hline Career Years ${ }^{\wedge} 3$ (in $1,000 s$ ) & $\begin{array}{c}0.117 * * * \\
(3.42)\end{array}$ \\
\hline Associate Professor & $\begin{array}{c}-0.501 * * * \\
(3.09)\end{array}$ \\
\hline Full Professor & $\begin{array}{c}-0.914 * * * \\
(4.06)\end{array}$ \\
\hline Chaired Full Professor & $\begin{array}{c}-1.169 * * * \\
(4.90)\end{array}$ \\
\hline Editor Impact & $\begin{array}{c}0.004 \\
0.00\end{array}$ \\
\hline Visiting & $\begin{array}{l}0.043 \\
(0.56)\end{array}$ \\
\hline Decade 1980 s & $\begin{array}{c}0.310 * * \\
(2.45)\end{array}$ \\
\hline Decade 1990s & $\begin{array}{c}0.993 * * * \\
(4.02)\end{array}$ \\
\hline Finance*Decade1970s & $\begin{array}{c}-1.024 * \\
(1.78)\end{array}$ \\
\hline Finance*Decade1980s & $\begin{array}{r}-0.883 \\
(1.53)\end{array}$ \\
\hline Finance*Decade1990s & $\begin{array}{l}-0.701 \\
(1.21)\end{array}$ \\
\hline Team*Decade1970s & $\begin{array}{c}0.160 * * \\
(2.76)\end{array}$ \\
\hline Team*Decade1980s & $\begin{array}{c}0.119 * * * \\
(3.60)\end{array}$ \\
\hline Team*Decade1990s & $\begin{array}{c}-0.131 * * * \\
(2.94)\end{array}$ \\
\hline Constant & $\begin{array}{c}4.342 * * * \\
(11.64)\end{array}$ \\
\hline Observations & 35,917 \\
\hline Individual Fixed Effects & Yes \\
\hline University Random Effects & Yes \\
\hline
\end{tabular}




\section{Table 9: Decomposition of University Fixed Effects}

The dependent variable is the field-decade university fixed effects from the estimation of Table 8 in which the team externality effect has been removed. Deadwood is decade average of each year's percentage of faculty who have not published an article in the prior two years. Editors In-House is the natural logarithm of the count of editors housed by the department for a year, averaged over the decade. Faculty Training Quality is the decade average percentage of faculty trained in top 5 schools, where the top 5 schools have the highest average productivity in the field for the decade. Ph.D. Program Quality is average number of students placed in top 25 universities from that department. Distance Metro is the natural log of the distance to the closest metropolitan area. State School is an indicator of whether the university is a public institution. Snowfall is the average snowfall in January for the university location. T-statistics are in parentheses. $* * *, * *$, and $*$ denote significance at the $1 \%, 5 \%$ and $10 \%$ levels respectively.

\begin{tabular}{|c|c|c|c|c|}
\hline \multicolumn{5}{|c|}{ Dependent Variable: University Fixed Effects Estimates } \\
\hline & \multicolumn{2}{|c|}{ Economics } & \multicolumn{2}{|c|}{ Finance } \\
\hline Editors In-House & $\begin{array}{c}-0.109 \\
(1.31)\end{array}$ & & $\begin{array}{c}-0.273 * * \\
(2.32)\end{array}$ & \\
\hline Editors In-House*Decade 1970s & & $\begin{array}{c}0.422 * * * \\
(3.66)\end{array}$ & & $\begin{array}{l}0.142 \\
(0.48)\end{array}$ \\
\hline Editors In-House *Decade 1980s & & $\begin{array}{c}0.193 * \\
(1.84)\end{array}$ & & $\begin{array}{l}-0.079 \\
(0.49)\end{array}$ \\
\hline Editors In-House *Decade 1990s & & $\begin{array}{l}-0.106 \\
(1.03)\end{array}$ & & $\begin{array}{c}-0.367 * * \\
(2.49)\end{array}$ \\
\hline Faculty Training Quality & $\begin{array}{c}1.384 * \\
(1.91)\end{array}$ & $\begin{array}{l}0.925 \\
(1.58)\end{array}$ & $\begin{array}{l}-0.955 \\
(1.50)\end{array}$ & $\begin{array}{l}-0.943 \\
(1.48)\end{array}$ \\
\hline Deadwood & $\begin{array}{c}-1.975 * * \\
(2.26)\end{array}$ & & $\begin{array}{c}-3.404 * * * \\
(5.66)\end{array}$ & \\
\hline Deadwood*1970s Decade & & $\begin{array}{l}-0.776 \\
(1.01)\end{array}$ & & $\begin{array}{c}-2.694 * * * \\
(4.05)\end{array}$ \\
\hline Deadwood*1980s Decade & & $\begin{array}{r}-1.242 \\
(1.59)\end{array}$ & & $\begin{array}{c}-3.739 * * * \\
(4.89)\end{array}$ \\
\hline Deadwood*1990s Decade & & $\begin{array}{r}-1.299 \\
(1.49)\end{array}$ & & $\begin{array}{c}-3.499 * * * \\
(5.18)\end{array}$ \\
\hline Ph.D. Program Quality & $\begin{array}{l}-0.083 \\
(0.59)\end{array}$ & $\begin{array}{c}-0.207 * \\
(1.77)\end{array}$ & $\begin{array}{l}0.195 \\
(0.74)\end{array}$ & $\begin{array}{l}0.326 \\
(1.26)\end{array}$ \\
\hline Distance Metro & $\begin{array}{l}0.052 \\
(0.95)\end{array}$ & $\begin{array}{l}0.023 \\
(0.52)\end{array}$ & $\begin{array}{l}0.083 \\
(1.20)\end{array}$ & $\begin{array}{l}0.082 \\
(1.21)\end{array}$ \\
\hline State School & $\begin{array}{l}-0.079 \\
(0.36)\end{array}$ & $\begin{array}{l}0.138 \\
(0.77)\end{array}$ & $\begin{array}{l}-0.179 \\
(0.65)\end{array}$ & $\begin{array}{r}-0.061 \\
(0.23)\end{array}$ \\
\hline Snowfall & $\begin{array}{l}0.001 \\
(0.11)\end{array}$ & $\begin{array}{l}0.004 \\
(1.02)\end{array}$ & $\begin{array}{c}-0.010 \\
(1.53)\end{array}$ & $\begin{array}{c}-0.012 * \\
(1.90)\end{array}$ \\
\hline Constant & $\begin{array}{l}0.557 \\
(0.98)\end{array}$ & $\begin{array}{r}-0.008 \\
(0.02) \\
\end{array}$ & $\begin{array}{c}2.337 * * * \\
(5.09)\end{array}$ & $\begin{array}{c}2.196 * * * \\
(4.85)\end{array}$ \\
\hline $\begin{array}{l}\text { Observations } \\
\text { Decade Random Effects }\end{array}$ & $\begin{array}{l}75 \\
\text { Yes } \\
\end{array}$ & $\begin{array}{l}75 \\
\text { Yes } \\
\end{array}$ & $\begin{array}{c}72 \\
\text { Yes } \\
\end{array}$ & $\begin{array}{c}72 \\
\text { Yes } \\
\end{array}$ \\
\hline $\begin{array}{l}\text { Partial R-Square (Type III SSE) } \\
\text { Model (R-Squared) }\end{array}$ & 0.21 & 0.53 & 0.42 & 0.50 \\
\hline Deadwood & 0.06 & 0.02 & 0.29 & 0.27 \\
\hline Editors & 0.02 & 0.16 & 0.05 & 0.06 \\
\hline Training of Faculty & 0.04 & 0.02 & 0.02 & 0.02 \\
\hline Ph.D. Program & 0.01 & 0.02 & 0.00 & 0.01 \\
\hline Metro Distance & 0.01 & 0.00 & 0.01 & 0.01 \\
\hline State School & 0.00 & 0.00 & 0.00 & 0.00 \\
\hline Snow & 0.00 & 0.00 & 0.02 & 0.03 \\
\hline Deadwood \& Editors together & 0.08 & 0.40 & 0.36 & 0.44 \\
\hline
\end{tabular}




\section{Table 10: Differences in Salaries SUR Estimation}

Salaries are the decade average university 9 or 10 month salaries as collected in the National Center of Education Statistics (HEGIS and IPEDS series) yearly survey broken down by assistant, associate and full professorship. F.E.Impact is the estimated university fixed effects for economics departments by decade. F.E.Individual is the estimated individual fixed effects for economics departments by decade. Differences are taken at the decade level. The difference estimations are fitted using a seemingly unrelated regression to capture cross-equation correlation in the errors. Z-statistics are in parentheses. ***,**, and * denote significance at the $1 \%, 5 \%$ and $10 \%$ levels respectively. The estimating equation is given by:

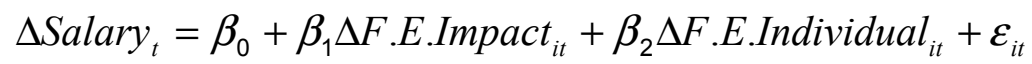

\begin{tabular}{crrr}
\hline & Coefficient & z-statistics \\
Assistant Professors & & & \\
$\Delta$ F.E.Impact & $\mathbf{- 1 , 3 8 5 . 8}$ & $* *$ & $\mathbf{( 2 . 2 3 )}$ \\
$\Delta$ F.E.Individual & 267.4 & & $(0.51)$ \\
Constant & $\mathbf{1 8 , 7 3 9 . 5}$ & $* * *$ & $\mathbf{( 2 8 . 4 4 )}$ \\
R-Squared & 0.059 & & \\
Observations & 94 & & \\
& & & \\
Associate Professors & & & \\
$\Delta$ F.E.Impact & $\mathbf{- 1 , 7 4 9 . 5}$ & $* * *$ & $\mathbf{( 2 . 4 5 )}$ \\
$\Delta$ F.E.Individual & 262.1 & & $(0.44)$ \\
Constant & $\mathbf{2 1 , 2 0 1 . 7}$ & $* * *$ & $\mathbf{( 2 8 . 0 1 )}$ \\
R-Squared & 0.032 & & \\
Observations & 94 & & \\
& & & \\
Full Professors & & & \\
$\Delta$ F.E.Impact & $\mathbf{- 2 , 9 1 6 . 5}$ & $* * *$ & $\mathbf{( 2 . 6 6 )}$ \\
$\Delta$ F.E.Individual & 902.4 & & $(0.98)$ \\
Constant & $\mathbf{3 1 , 7 5 0 . 8}$ & $* * *$ & $\mathbf{( 2 7 . 2 6 )}$ \\
R-Squared & 0.091 & & \\
Observations & 94 & &
\end{tabular}




\section{Appendix 2 Panel A: Determinants of Faculty Productivity by Rank}

Observations are at the individual-year level. Impact and raw productivities are measured as the count of AER equivalent pages written by each faculty in 41 economics and finance journals. Adjustment to $A E R$ equivalents normalizes by font, typesetting and average article length. Publication pages are divided by $1 / \mathrm{n}$ coauthors. Impact productivity multiplies each article by the decade impact factor of the journal published given in Table 2. Article count is the simple sum of articles published by year. The 1990s decade includes 2000 and 2001. Career years is the years since Ph.D. Associate and Full Professor, Chaired, and Visiting are indicator variables for the position of the faculty. Editor impact is the sum of the impact factors for the journals for which the faculty serves as an editor or co-editor. All columns include individual fixed effects. Columns 2, 4 and 6 add university-field fixed effects. Article counts are estimated with Poisson Regression. T-statistics are in parentheses. ***,**, and $*$ denote significance at the $1 \%$, $5 \%$ and $10 \%$ levels respectively.

\begin{tabular}{|c|c|c|c|c|c|c|}
\hline Dependent Variable: & \multicolumn{2}{|c|}{ Impact Productivity } & \multicolumn{2}{|c|}{ Raw Productivity } & \multicolumn{2}{|c|}{ Article Count } \\
\hline \multirow[b]{2}{*}{ Career Years } & 1 & 2 & 3 & 4 & 5 & 6 \\
\hline & $\begin{array}{c}-0.102 * * * \\
(2.63)\end{array}$ & $\begin{array}{c}-0.072 * \\
(1.80)\end{array}$ & $\begin{array}{c}-0.100 \\
(1.31)\end{array}$ & $\begin{array}{c}-0.044 \\
(0.56)\end{array}$ & $\begin{array}{c}0.025 * * * \\
(4.08)\end{array}$ & $\begin{array}{c}0.029 * * * \\
(4.65)\end{array}$ \\
\hline Career Years ${ }^{\wedge} 2$ & $\begin{array}{r}-0.001 \\
(0.72)\end{array}$ & $\begin{array}{c}-0.004 * \\
(1.93)\end{array}$ & $\begin{array}{c}-0.006 \\
(1.53)\end{array}$ & $\begin{array}{c}-0.010 * * \\
(2.38)\end{array}$ & $\begin{array}{c}-0.004 * * * \\
(10.10)\end{array}$ & $\begin{array}{c}-0.004 * * * \\
(10.49)\end{array}$ \\
\hline Career Years`3 $(1,000 \mathrm{~s})$ & $\begin{array}{l}0.045 \\
(1.51)\end{array}$ & $\begin{array}{c}0.092 * * * \\
(2.68)\end{array}$ & $\begin{array}{c}0.122 * \\
(1.85)\end{array}$ & $\begin{array}{c}0.198 * * * \\
(2.63)\end{array}$ & $\begin{array}{c}0.056^{* * *} \\
(7.85)\end{array}$ & $\begin{array}{c}0.061 * * * \\
(8.28)\end{array}$ \\
\hline Chaired Full Professor & $\begin{array}{c}-0.282 * * \\
(2.27)\end{array}$ & $\begin{array}{c}-0.416 * * * \\
(4.06)\end{array}$ & $\begin{array}{c}-0.444 * * \\
(2.50)\end{array}$ & $\begin{array}{c}-0.696 * * * \\
(4.69)\end{array}$ & $\begin{array}{c}0.050 * \\
(1.87)\end{array}$ & $\begin{array}{r}-0.019 \\
(0.51)\end{array}$ \\
\hline Editor Impact & $\begin{array}{l}0.092 \\
(0.12)\end{array}$ & $\begin{array}{l}0.077 \\
(0.09)\end{array}$ & $\begin{array}{l}0.046 \\
(0.04)\end{array}$ & $\begin{array}{l}0.060 \\
(0.05)\end{array}$ & $\begin{array}{l}0.050 \\
(0.87)\end{array}$ & $\begin{array}{l}0.023 \\
(0.38)\end{array}$ \\
\hline Visiting & $\begin{array}{l}0.032 \\
(0.37)\end{array}$ & $\begin{array}{l}0.037 \\
(0.45)\end{array}$ & $\begin{array}{l}0.162 \\
(0.93)\end{array}$ & $\begin{array}{l}0.142 \\
(0.84)\end{array}$ & $\begin{array}{c}0.053 * \\
(1.85)\end{array}$ & $\begin{array}{l}0.034 \\
(1.15)\end{array}$ \\
\hline Decade 1980 s & $\begin{array}{c}0.449 * * \\
(2.32)\end{array}$ & $\begin{array}{c}0.725 * * * \\
(3.20)\end{array}$ & $\begin{array}{c}1.265 * * * \\
(3.72)\end{array}$ & $\begin{array}{c}1.986 * * * \\
(5.79)\end{array}$ & $\begin{array}{c}0.078 * * \\
(1.99)\end{array}$ & $\begin{array}{c}0.150 * * * \\
(2.59)\end{array}$ \\
\hline Decade 1990s & $\begin{array}{c}0.772 * * * \\
(2.62)\end{array}$ & $\begin{array}{c}1.657 * * * \\
(3.15)\end{array}$ & $\begin{array}{c}2.239 * * * \\
(3.98)\end{array}$ & $\begin{array}{c}4.036 * * * \\
(4.69)\end{array}$ & $\begin{array}{c}0.041 \\
(0.71)\end{array}$ & $\begin{array}{c}0.175^{* *} \\
(2.36)\end{array}$ \\
\hline Finance*Decade1970s & $\begin{array}{c}-1.229 * * \\
(2.12)\end{array}$ & $\begin{array}{r}-1.327 \\
(1.20)\end{array}$ & $\begin{array}{r}-0.308 \\
(0.32)\end{array}$ & $\begin{array}{l}0.793 \\
(0.46)\end{array}$ & $\begin{array}{c}0.344 * \\
(1.70)\end{array}$ & $\begin{array}{c}0.497 * * \\
(2.08)\end{array}$ \\
\hline Finance*Decade1980s & $\begin{array}{c}-1.150 * * \\
(2.36)\end{array}$ & $\begin{array}{c}-1.160 \\
(1.10)\end{array}$ & $\begin{array}{r}-0.921 \\
(1.07)\end{array}$ & $\begin{array}{l}-0.026 \\
(0.02)\end{array}$ & $\begin{array}{l}0.058 \\
(0.29)\end{array}$ & $\begin{array}{l}0.116 \\
(0.52)\end{array}$ \\
\hline Finance*Decade1990s & $\begin{array}{c}-1.166 * * \\
(2.36)\end{array}$ & $\begin{array}{c}-1.278 \\
(1.40)\end{array}$ & $\begin{array}{c}-1.717 * \\
(1.85)\end{array}$ & $\begin{array}{c}-1.240 \\
(0.83)\end{array}$ & $\begin{array}{c}-0.150 \\
(0.75)\end{array}$ & $\begin{array}{l}-0.193 \\
(0.86)\end{array}$ \\
\hline Full*Decade 1970 s & $\begin{array}{c}0.203 \\
(0.77)\end{array}$ & $\begin{array}{c}0.684 * * \\
(2.46)\end{array}$ & $\begin{array}{l}0.198 \\
(0.35)\end{array}$ & $\begin{array}{c}1.239 * * * \\
(2.63)\end{array}$ & $\begin{array}{r}-0.074 \\
(1.62)\end{array}$ & $\begin{array}{l}0.008 \\
(0.13)\end{array}$ \\
\hline Full*Decade 1980 s & $\begin{array}{c}-0.436 * * * \\
(2.60)\end{array}$ & $\begin{array}{r}-0.115 \\
(0.70)\end{array}$ & $\begin{array}{c}-0.805 * * \\
(2.44)\end{array}$ & $\begin{array}{r}-0.245 \\
(0.92)\end{array}$ & $\begin{array}{c}-0.130 * * * \\
(3.55)\end{array}$ & $\begin{array}{r}-0.072 \\
(1.46)\end{array}$ \\
\hline Full*Decade $1990 \mathrm{~s}$ & $\begin{array}{c}-0.824 * * * \\
(2.69)\end{array}$ & $\begin{array}{c}-0.623 * * \\
(2.37)\end{array}$ & $\begin{array}{c}-1.594 * * * \\
(3.41)\end{array}$ & $\begin{array}{c}-1.428 * * * \\
(3.40)\end{array}$ & $\begin{array}{c}-0.058 \\
(1.45)\end{array}$ & $\begin{array}{l}0.010 \\
(0.19)\end{array}$ \\
\hline Full*Finance*1970s & $\begin{array}{c}-0.037 \\
(0.09)\end{array}$ & $\begin{array}{l}0.079 \\
(0.11)\end{array}$ & $\begin{array}{r}-0.316 \\
(0.38)\end{array}$ & $\begin{array}{c}-0.802 \\
(0.59)\end{array}$ & $\begin{array}{c}-0.160 * \\
(1.73)\end{array}$ & $\begin{array}{c}-0.374 * * \\
(2.33)\end{array}$ \\
\hline Full*Finance*1980s & $\begin{array}{l}0.002 \\
(0.01)\end{array}$ & $\begin{array}{l}0.321 \\
(0.74)\end{array}$ & $\begin{array}{l}-0.127 \\
(0.23)\end{array}$ & $\begin{array}{l}0.176 \\
(0.25)\end{array}$ & $\begin{array}{r}-0.095 \\
(1.34)\end{array}$ & $\begin{array}{c}-0.076 \\
(0.79)\end{array}$ \\
\hline Full*Finance*1990s & $\begin{array}{l}0.191 \\
(0.50)\end{array}$ & $\begin{array}{l}0.282 \\
(0.73)\end{array}$ & $\begin{array}{l}0.587 \\
(0.92)\end{array}$ & $\begin{array}{l}1.004 \\
(1.61)\end{array}$ & $\begin{array}{r}-0.023 \\
(0.32)\end{array}$ & $\begin{array}{c}0.006 \\
(0.08)\end{array}$ \\
\hline Constant & $\begin{array}{c}4.607 * * * \\
(12.36)\end{array}$ & $\begin{array}{c}3.821 * * * \\
(10.38)\end{array}$ & $\begin{array}{c}7.640 * * * \\
(11.00)\end{array}$ & $\begin{array}{c}5.671 * * * \\
(9.45)\end{array}$ & & \\
\hline Observations & 35,917 & 35,917 & 35,917 & 35,917 & 35,917 & 35,917 \\
\hline Individual Fixed Effects & Yes & Yes & Yes & Yes & Yes & Yes \\
\hline University Fixed Effects & No & Yes & No & Yes & No & Yes \\
\hline
\end{tabular}


Appendix 2, Panel B: University Fixed Effects for Assistant \& Associate Professors University fixed effects estimates for the impact productivity estimation from Appendix 2, Panel A, Column 2.

\begin{tabular}{|c|c|c|c|c|c|c|}
\hline & \multicolumn{6}{|c|}{ Dependent Variable: Impact Productivity } \\
\hline \multirow[b]{3}{*}{ Carnegie Mellon } & \multicolumn{3}{|c|}{ Economics Departments } & \multicolumn{3}{|c|}{ Finance Departments } \\
\hline & $1970 \mathrm{~s}$ & $1980 \mathrm{~s}$ & 1990s & 1970s & $1980 \mathrm{~s}$ & 1990s \\
\hline & $\begin{array}{c}-1.008 * * \\
(2.23)\end{array}$ & $\begin{array}{l}0.272 \\
(1.26)\end{array}$ & $\begin{array}{c}0.338 * * \\
(2.14)\end{array}$ & $\begin{array}{c}1.888 * * * \\
(6.53)\end{array}$ & $\begin{array}{l}-0.045 \\
(0.09)\end{array}$ & $\begin{array}{c}-1.432 * * \\
(2.05)\end{array}$ \\
\hline Columbia & $\begin{array}{c}1.676 * * * \\
(6.45)\end{array}$ & $\begin{array}{l}0.123 \\
(0.44)\end{array}$ & $\begin{array}{c}-1.180 * * \\
(2.41)\end{array}$ & $\begin{array}{c}1.328 * * * \\
(7.34)\end{array}$ & $\begin{array}{l}0.096 \\
(0.44)\end{array}$ & $\begin{array}{l}-0.113 \\
(0.55)\end{array}$ \\
\hline Cornell & $\begin{array}{c}-0.261 \\
(1.18)\end{array}$ & $\begin{array}{l}-0.209 \\
(0.68)\end{array}$ & $\begin{array}{c}-0.448 \\
(1.35)\end{array}$ & $\begin{array}{l}0.393 \\
(1.13)\end{array}$ & $\begin{array}{l}-0.157 \\
(0.65)\end{array}$ & $\begin{array}{l}-0.580 \\
(1.31)\end{array}$ \\
\hline Duke & $\begin{array}{c}-0.604 * * * \\
(3.27)\end{array}$ & $\begin{array}{c}1.099 * * * \\
(4.21)\end{array}$ & $\begin{array}{c}-0.532 * * \\
(2.35)\end{array}$ & $\begin{array}{c}-0.830 * * * \\
(3.51)\end{array}$ & $\begin{array}{c}0.461 \\
(1.64)\end{array}$ & $\begin{array}{c}0.848 * * \\
(2.43)\end{array}$ \\
\hline Harvard & $\begin{array}{c}2.012 * * * \\
(10.40)\end{array}$ & $\begin{array}{c}0.548 * * \\
(2.25)\end{array}$ & $\begin{array}{c}-1.284 * * * \\
(4.05)\end{array}$ & $\begin{array}{c}-1.640 * * * \\
(3.22)\end{array}$ & $\begin{array}{c}-1.498 * * \\
(2.38)\end{array}$ & $\begin{array}{c}-2.762 * * \\
(2.00)\end{array}$ \\
\hline Indiana & $\begin{array}{c}1.492 * * * \\
(7.55)\end{array}$ & $\begin{array}{c}0.732 * * * \\
(4.09)\end{array}$ & $\begin{array}{r}-0.052 \\
(0.21)\end{array}$ & $\begin{array}{c}2.165 * * * \\
(8.85)\end{array}$ & $\begin{array}{c}-0.869 * * * \\
(2.58)\end{array}$ & $\begin{array}{c}0.439 * * * \\
(2.77)\end{array}$ \\
\hline MIT & $\begin{array}{c}\mathbf{0 . 4 8 8 *} \\
(1.84)\end{array}$ & $\begin{array}{c}0.957 * * * \\
(3.75)\end{array}$ & $\begin{array}{c}-0.780 * * * \\
(2.59)\end{array}$ & $\begin{array}{c}1.989 * * * \\
(2.61)\end{array}$ & $\begin{array}{l}2.366 \\
(1.63)\end{array}$ & $\begin{array}{r}-0.029 \\
(0.05)\end{array}$ \\
\hline New York U & $\begin{array}{l}0.331 \\
(1.06)\end{array}$ & $\begin{array}{r}-0.374 \\
(0.80)\end{array}$ & $\begin{array}{r}-0.021 \\
(0.04)\end{array}$ & $\begin{array}{c}1.639 * * * \\
(6.66)\end{array}$ & $\begin{array}{l}0.613 \\
(1.51)\end{array}$ & $\begin{array}{c}2.047 * * * \\
(9.02)\end{array}$ \\
\hline Northwestern & $\begin{array}{c}0.920 * * * \\
(5.08)\end{array}$ & $\begin{array}{c}2.252 * * * \\
(15.09)\end{array}$ & $\begin{array}{c}-0.343 \\
(1.17)\end{array}$ & $\begin{array}{c}0.884 * \\
(1.95)\end{array}$ & $\begin{array}{c}1.097 * * * \\
(4.05)\end{array}$ & $\begin{array}{r}-0.237 \\
(0.70)\end{array}$ \\
\hline Ohio State U & $\begin{array}{c}1.551 * * * \\
(7.95)\end{array}$ & $\begin{array}{l}0.358 \\
(1.64)\end{array}$ & $\begin{array}{c}0.758 * * \\
(1.97)\end{array}$ & $\begin{array}{c}2.498 * * * \\
(9.77)\end{array}$ & $\begin{array}{c}0.543 * * * \\
(3.08)\end{array}$ & $\begin{array}{l}-0.653 \\
(1.37)\end{array}$ \\
\hline Princeton & $\begin{array}{c}1.064 * * * \\
(3.50)\end{array}$ & $\begin{array}{c}2.573 * * * \\
(7.97)\end{array}$ & $\begin{array}{l}0.513 \\
(0.98)\end{array}$ & & & \\
\hline Purdue & $\begin{array}{l}0.161 \\
(0.27)\end{array}$ & $\begin{array}{c}-0.954 * * * \\
(5.74)\end{array}$ & $\begin{array}{c}-0.992 * * * \\
(2.77)\end{array}$ & $\begin{array}{l}0.629 \\
(1.48)\end{array}$ & $\begin{array}{c}1.483 * * * \\
(2.93)\end{array}$ & $\begin{array}{l}0.554 \\
(1.10)\end{array}$ \\
\hline Stanford & $\begin{array}{c}1.771 * * * \\
(9.86)\end{array}$ & $\begin{array}{c}1.240 * * * \\
(5.58)\end{array}$ & $\begin{array}{r}-0.405 \\
(1.03)\end{array}$ & $\begin{array}{c}1.129 * * * \\
(4.41)\end{array}$ & $\begin{array}{c}3.932 * * * \\
(12.28)\end{array}$ & $\begin{array}{l}0.649 \\
(1.05)\end{array}$ \\
\hline U British Columbia & $\begin{array}{c}0.954 * * * \\
(3.78)\end{array}$ & $\begin{array}{l}0.117 \\
(0.51)\end{array}$ & $\begin{array}{c}0.703 * * \\
(2.15)\end{array}$ & $\begin{array}{c}2.945 * * \\
(2.43)\end{array}$ & $\begin{array}{l}0.247 \\
(1.23)\end{array}$ & $\begin{array}{l}0.266 \\
(0.81)\end{array}$ \\
\hline UC Berkeley & $\begin{array}{c}-0.399 * * \\
(2.45)\end{array}$ & $\begin{array}{l}0.305 \\
(1.20)\end{array}$ & $\begin{array}{l}-0.667 \\
(1.64)\end{array}$ & $\begin{array}{l}0.309 \\
(0.81)\end{array}$ & $\begin{array}{c}0.602 \\
(1.61)\end{array}$ & $\begin{array}{l}-0.641 \\
(1.51)\end{array}$ \\
\hline UC Los Angeles & $\begin{array}{l}2.110 * * * \\
(6.27)\end{array}$ & $\begin{array}{c}-0.256 \\
(0.62)\end{array}$ & $\begin{array}{l}-0.707 \\
(1.49)\end{array}$ & $\begin{array}{c}2.268 * * * \\
(14.13)\end{array}$ & $\begin{array}{c}1.521 * * * \\
(3.83)\end{array}$ & $\begin{array}{l}-0.522 \\
(1.16)\end{array}$ \\
\hline U of Chicago & $\begin{array}{c}2.470 * * * \\
(11.33)\end{array}$ & $\begin{array}{c}0.881 * * * \\
(4.00)\end{array}$ & $\begin{array}{l}-0.210 \\
(0.71)\end{array}$ & $\begin{array}{c}2.709 * * * \\
(9.02)\end{array}$ & $\begin{array}{c}2.063 * * * \\
(8.40)\end{array}$ & $\begin{array}{l}-0.262 \\
(0.69)\end{array}$ \\
\hline U of Michigan & $\begin{array}{c}1.301 * * * \\
(5.88)\end{array}$ & $\begin{array}{c}1.828 * * * \\
(5.16)\end{array}$ & $\begin{array}{l}0.063 \\
(0.24)\end{array}$ & $\begin{array}{c}1.832 * * * \\
(4.10)\end{array}$ & $\begin{array}{c}1.201 * * * \\
(2.81)\end{array}$ & $\begin{array}{l}-0.196 \\
(0.78)\end{array}$ \\
\hline U of Pennsylvania & $\begin{array}{c}1.366 * * * \\
(4.97)\end{array}$ & $\begin{array}{c}1.063 * * * \\
(6.28)\end{array}$ & $\begin{array}{r}-0.287 \\
(1.25)\end{array}$ & $\begin{array}{c}0.728 * * * \\
(4.54)\end{array}$ & $\begin{array}{c}-0.393 \\
(1.55)\end{array}$ & $\begin{array}{l}-0.173 \\
(0.65)\end{array}$ \\
\hline $\mathrm{U}$ of Rochester & $\begin{array}{l}0.411 \\
(1.23)\end{array}$ & $\begin{array}{c}1.569 * * * \\
(5.28)\end{array}$ & $\begin{array}{c}0.914 * * * \\
(2.99)\end{array}$ & $\begin{array}{r}-0.469 \\
(0.92)\end{array}$ & $\begin{array}{c}-1.410 * * * * \\
(4.88)\end{array}$ & $\begin{array}{l}0.380 \\
(0.98)\end{array}$ \\
\hline U of Southern Calif. & $\begin{array}{c}0.428 * * \\
(2.43)\end{array}$ & $\begin{array}{r}-0.313 \\
(1.59)\end{array}$ & $\begin{array}{l}0.338 \\
(1.15)\end{array}$ & $\begin{array}{l}0.460 \\
(0.75)\end{array}$ & $\begin{array}{c}1.513 * * * \\
(4.48)\end{array}$ & $\begin{array}{l}-0.471 \\
(1.41)\end{array}$ \\
\hline $\mathrm{U}$ of Texas & $\begin{array}{c}1.330 * * * \\
(4.44)\end{array}$ & $\begin{array}{l}-0.355 \\
(1.53)\end{array}$ & $\begin{array}{l}0.255 \\
(0.41)\end{array}$ & $\begin{array}{l}-0.369 \\
(1.17)\end{array}$ & $\begin{array}{l}0.023 \\
(0.09)\end{array}$ & $\begin{array}{l}-0.396 \\
(0.54)\end{array}$ \\
\hline $\mathrm{U}$ of Washington & $\begin{array}{l}0.142 \\
(0.39)\end{array}$ & $\begin{array}{l}-0.237 \\
(0.77)\end{array}$ & $\begin{array}{c}-2.093 * * * \\
(5.59)\end{array}$ & $\begin{array}{c}1.110 * * \\
(1.99)\end{array}$ & $\begin{array}{l}1.062 \\
(1.08)\end{array}$ & $\begin{array}{l}-1.071 \\
(0.95)\end{array}$ \\
\hline U of Wisconsin & $\begin{array}{c}0.784 * * * \\
(4.94)\end{array}$ & $\begin{array}{l}-0.299 \\
(1.19)\end{array}$ & $\begin{array}{r}-0.541 \\
(1.23)\end{array}$ & $\begin{array}{l}-0.270 \\
(0.52)\end{array}$ & $\begin{array}{c}0.593 * * * \\
(3.32)\end{array}$ & $\begin{array}{l}0.654 * \\
(1.96)\end{array}$ \\
\hline Yale & $\begin{array}{c}1.987 * * * \\
(7.08)\end{array}$ & $\begin{array}{l}-0.305 \\
(0.80)\end{array}$ & $\begin{array}{l}0.395 \\
(1.06)\end{array}$ & $\begin{array}{c}3.573 * * * \\
(7.61)\end{array}$ & $\begin{array}{c}\text { 0.744* } \\
(1.86)\end{array}$ & $\begin{array}{c}-1.763 * * * \\
(3.95)\end{array}$ \\
\hline Significant (+) Count & 17 & 11 & 4 & 15 & 10 & 4 \\
\hline Significant (-) Count & 3 & 1 & 6 & 2 & 3 & 3 \\
\hline
\end{tabular}


Appendix 2, Panel C: University Fixed Effects for Full Professors

University fixed effects estimates for the impact productivity estimation from Appendix 2, Panel A, Column 2.

\begin{tabular}{|c|c|c|c|c|c|c|}
\hline & \multicolumn{6}{|c|}{ Dependent Variable: Impact Productivity } \\
\hline & \multicolumn{3}{|c|}{ Economics Departments } & \multicolumn{3}{|c|}{ Finance Departments } \\
\hline & 1970s & $1980 \mathrm{~s}$ & 1990s & $1970 s$ & $1980 \mathrm{~s}$ & $1990 \mathrm{~s}$ \\
\hline Carnegie Mellon & $\begin{array}{c}-1.080 * * * \\
(3.90)\end{array}$ & $\begin{array}{c}1.276 * * * \\
(5.06)\end{array}$ & $\begin{array}{l}-0.513 \\
(1.50)\end{array}$ & & $\begin{array}{c}3.250 * * * \\
(4.79)\end{array}$ & $\begin{array}{c}-1.431 * \\
(1.71)\end{array}$ \\
\hline Columbia & $\begin{array}{c}-0.066 \\
(0.16)\end{array}$ & $\begin{array}{r}-0.281 \\
(0.47)\end{array}$ & $\begin{array}{l}0.100 \\
(0.25)\end{array}$ & $\begin{array}{c}0.494 \\
(0.85)\end{array}$ & $\begin{array}{c}-1.003 * * * \\
(2.79)\end{array}$ & $\begin{array}{c}-0.756 * * \\
(2.28)\end{array}$ \\
\hline Cornell & $\begin{array}{l}-0.410 \\
(0.92)\end{array}$ & $\begin{array}{c}-0.504 \\
(0.83)\end{array}$ & $\begin{array}{c}-0.025 \\
(0.05)\end{array}$ & $\begin{array}{c}-2.157 * * * \\
(5.12)\end{array}$ & $\begin{array}{c}-2.064 * * * \\
(11.05)\end{array}$ & $\begin{array}{c}-0.679 * * \\
(2.51)\end{array}$ \\
\hline Duke & $\begin{array}{c}-0.521 * \\
(1.84)\end{array}$ & $\begin{array}{c}-0.540 * * \\
(2.24)\end{array}$ & $\begin{array}{c}-0.746 * * * \\
(2.93)\end{array}$ & & $\begin{array}{c}-2.329 * * * \\
(5.19)\end{array}$ & $\begin{array}{c}-2.094 * * * \\
(6.88)\end{array}$ \\
\hline Harvard & $\begin{array}{c}2.394 * * * \\
(10.11)\end{array}$ & $\begin{array}{c}0.218 \\
(0.82)\end{array}$ & $\begin{array}{c}-2.248 * * * \\
(6.07)\end{array}$ & $\begin{array}{c}-3.889 * * * \\
(4.80)\end{array}$ & $\begin{array}{c}-3.497 * * * \\
(4.64)\end{array}$ & $\begin{array}{c}-1.752 * * \\
(2.32)\end{array}$ \\
\hline Indiana & $\begin{array}{c}-1.117 * * * * \\
(3.46)\end{array}$ & $\begin{array}{l}0.351 \\
(1.18)\end{array}$ & $\begin{array}{r}-0.109 \\
(0.33)\end{array}$ & $\begin{array}{c}-0.808 * * * * \\
(4.72)\end{array}$ & $\begin{array}{c}-1.026 * * * \\
(3.28)\end{array}$ & $\begin{array}{c}-0.808 * * * \\
(4.72)\end{array}$ \\
\hline MIT & $\begin{array}{c}0.912 * * * \\
(4.04)\end{array}$ & $\begin{array}{l}0.177 \\
(0.65)\end{array}$ & $\begin{array}{c}-1.569 * * * \\
(3.34)\end{array}$ & $\begin{array}{l}0.101 \\
(0.09)\end{array}$ & $\begin{array}{r}-1.049 \\
(0.93)\end{array}$ & $\begin{array}{r}-0.512 \\
(0.65)\end{array}$ \\
\hline New York U & $\begin{array}{c}-1.474 * * * \\
(2.66)\end{array}$ & $\begin{array}{l}-0.589 \\
(0.86)\end{array}$ & $\begin{array}{r}-0.459 \\
(0.74)\end{array}$ & $\begin{array}{l}0.019 \\
(0.04)\end{array}$ & $\begin{array}{c}-0.440 * * \\
(2.49)\end{array}$ & $\begin{array}{c}-0.444 * * * \\
(2.67)\end{array}$ \\
\hline Northwestern & $\begin{array}{l}0.347 \\
(1.06)\end{array}$ & $\begin{array}{l}0.480 \\
(1.41)\end{array}$ & $\begin{array}{c}1.273 * * * \\
(2.66)\end{array}$ & $\begin{array}{l}-0.465 \\
(1.11)\end{array}$ & $\begin{array}{l}0.021 \\
(0.08)\end{array}$ & $\begin{array}{l}0.200 \\
(0.70)\end{array}$ \\
\hline Ohio State U & $\begin{array}{c}1.771 * * * \\
(4.16)\end{array}$ & $\begin{array}{c}-0.978 * * \\
(2.16)\end{array}$ & $\begin{array}{c}-2.001 * * \\
(2.42)\end{array}$ & $\begin{array}{l}1.565^{*} \\
(1.85)\end{array}$ & $\begin{array}{c}-2.291 * \\
(1.71)\end{array}$ & $\begin{array}{l}0.369 \\
(0.13)\end{array}$ \\
\hline Princeton & $\begin{array}{c}0.669 * * \\
(2.42)\end{array}$ & $\begin{array}{l}0.228 \\
(0.55)\end{array}$ & $\begin{array}{c}-1.592 * * * \\
(3.99)\end{array}$ & & & \\
\hline Purdue & $\begin{array}{l}-0.423 \\
(1.06)\end{array}$ & $\begin{array}{l}-0.084 \\
(0.15)\end{array}$ & $\begin{array}{r}-0.587 \\
(1.51)\end{array}$ & $\begin{array}{c}3.030 * * * \\
(7.16)\end{array}$ & $\begin{array}{c}3.234 * * * \\
(3.30)\end{array}$ & $\begin{array}{l}-0.898 \\
(0.33)\end{array}$ \\
\hline Stanford & $\begin{array}{l}0.204 \\
(0.73)\end{array}$ & $\begin{array}{c}-0.819 * * \\
(2.42)\end{array}$ & $\begin{array}{c}-1.824 * * * \\
(5.47)\end{array}$ & $\begin{array}{c}1.056 * \\
(1.71)\end{array}$ & $\begin{array}{l}0.552 \\
(1.20)\end{array}$ & $\begin{array}{c}2.712 * * * \\
(5.23)\end{array}$ \\
\hline U British Columbia & $\begin{array}{l}-0.265 \\
(0.70)\end{array}$ & $\begin{array}{l}0.043 \\
(0.11)\end{array}$ & $\begin{array}{l}0.152 \\
(0.59)\end{array}$ & $\begin{array}{l}1.472 \\
(1.23)\end{array}$ & $\begin{array}{l}0.806 \\
(0.69)\end{array}$ & $\begin{array}{l}1.472 \\
(1.23)\end{array}$ \\
\hline UC Berkeley & $\begin{array}{c}-0.702 * \\
(1.94)\end{array}$ & $\begin{array}{c}-0.400 * \\
(1.69)\end{array}$ & $\begin{array}{c}-0.914 * * * \\
(4.23)\end{array}$ & $\begin{array}{l}-0.059 \\
(0.10)\end{array}$ & $\begin{array}{c}-3.081 * * * \\
(4.94)\end{array}$ & $\begin{array}{c}1.795 * * * \\
(3.30)\end{array}$ \\
\hline UC Los Angeles & $\begin{array}{l}0.896 \\
(1.28)\end{array}$ & $\begin{array}{c}\text { 1.099* } \\
\text { (1.93) }\end{array}$ & $\begin{array}{c}-0.152 \\
(0.43)\end{array}$ & $\begin{array}{c}1.446 * * \\
(2.35)\end{array}$ & $\begin{array}{c}-1.148 * \\
(1.75)\end{array}$ & $\begin{array}{c}1.408 * * * \\
(4.07)\end{array}$ \\
\hline U of Chicago & $\begin{array}{c}0.580 * * \\
(2.13)\end{array}$ & $\begin{array}{c}0.653 * * * \\
(2.73)\end{array}$ & $\begin{array}{l}-0.257 \\
(1.10)\end{array}$ & $\begin{array}{c}1.472 * * * \\
(2.98)\end{array}$ & $\begin{array}{l}-0.105 \\
(0.20)\end{array}$ & $\begin{array}{c}-0.766 * \\
(1.70)\end{array}$ \\
\hline U of Michigan & $\begin{array}{l}0.020 \\
(0.09)\end{array}$ & $\begin{array}{c}0.630 * * * \\
(2.70)\end{array}$ & $\begin{array}{c}0.459 * * \\
(2.15)\end{array}$ & $\begin{array}{c}1.239 * * * \\
(3.27)\end{array}$ & $\begin{array}{c}1.553 * * * \\
(6.43)\end{array}$ & $\begin{array}{c}-2.633 * * * \\
(7.26)\end{array}$ \\
\hline U of Pennsylvania & $\begin{array}{c}0.869 * * \\
(2.44)\end{array}$ & $\begin{array}{c}0.779 * * \\
(2.28)\end{array}$ & $\begin{array}{l}0.170 \\
(1.00)\end{array}$ & $\begin{array}{l}0.261 \\
(1.20)\end{array}$ & $\begin{array}{l}-0.170 \\
(0.41)\end{array}$ & $\begin{array}{l}0.522 \\
(1.31)\end{array}$ \\
\hline U of Rochester & $\begin{array}{c}2.084 * * * \\
(7.46)\end{array}$ & $\begin{array}{c}2.203 * * * \\
(9.42)\end{array}$ & $\begin{array}{c}-0.789 * * \\
(2.14)\end{array}$ & $\begin{array}{c}1.975 * * \\
(2.09)\end{array}$ & $\begin{array}{l}0.427 \\
(0.60)\end{array}$ & $\begin{array}{c}-1.804 * * * \\
(6.03)\end{array}$ \\
\hline $\mathrm{U}$ of Southern Calif. & $\begin{array}{l}0.060 \\
(0.24)\end{array}$ & $\begin{array}{c}-0.408 * * * \\
(2.67)\end{array}$ & $\begin{array}{c}-0.114 \\
(0.45)\end{array}$ & $\begin{array}{c}-1.180 * \\
(1.95)\end{array}$ & $\begin{array}{c}-0.722 * * * \\
(2.84)\end{array}$ & $\begin{array}{c}-0.722 * * * \\
(2.84)\end{array}$ \\
\hline $\mathrm{U}$ of Texas & $\begin{array}{c}-1.506^{* * *} \\
(2.50)\end{array}$ & $\begin{array}{c}-0.184 \\
(0.33)\end{array}$ & $\begin{array}{c}-0.644 \\
(1.06)\end{array}$ & $\begin{array}{c}-1.395 * * \\
(2.15)\end{array}$ & $\begin{array}{r}-0.607 \\
(1.33)\end{array}$ & $\begin{array}{c}0.158 \\
(0.39)\end{array}$ \\
\hline $\mathrm{U}$ of Washington & $\begin{array}{c}-1.452 * * * * \\
(3.45)\end{array}$ & $\begin{array}{l}-0.482 \\
(0.99)\end{array}$ & $\begin{array}{c}-0.757 * * \\
(2.09)\end{array}$ & $\begin{array}{c}-0.211 \\
(0.16)\end{array}$ & $\begin{array}{l}-1.369 \\
(1.19)\end{array}$ & $\begin{array}{l}-1.123 \\
(1.24)\end{array}$ \\
\hline $\mathrm{U}$ of Wisconsin & $\begin{array}{c}-0.314 * \\
(1.75)\end{array}$ & $\begin{array}{l}-0.114 \\
(0.65)\end{array}$ & $\begin{array}{c}-0.550 \\
(1.39)\end{array}$ & $\begin{array}{c}1.088 * * * \\
(2.80)\end{array}$ & $\begin{array}{c}-0.390 \\
(1.21)\end{array}$ & $\begin{array}{c}0.721 * * * \\
(3.00)\end{array}$ \\
\hline Yale & $\begin{array}{c}-1.745 * * * \\
(3.61) \\
\end{array}$ & $\begin{array}{l}-0.117 \\
(0.22) \\
\end{array}$ & $\begin{array}{c}-1.092 * * \\
(2.23)\end{array}$ & $\begin{array}{c}-1.863 * * * \\
(3.99) \\
\end{array}$ & $\begin{array}{c}1.798 * * * \\
(2.78)\end{array}$ & $\begin{array}{r}-0.853 \\
(1.10) \\
\end{array}$ \\
\hline Significant (+) Count & 7 & 6 & 2 & 8 & 4 & 4 \\
\hline Significant (-) Count & 9 & 5 & 10 & 6 & 9 & 12 \\
\hline
\end{tabular}


